\title{
A Systemic Prognosis of Architectural Interventions
}

by

Greg Fung

A thesis submitted to the Faculty of Graduate and Postdoctoral Affairs in partial fulfillment of the requirements for the degree of

\section{Master of Architecture}

Azrieli School of Architecture \& Urbanism

Carleton University

Ottawa, Ontario

(C) 2012

Greg Fung 
Library and Archives

Canada

Published Heritage

Branch

395 Wellington Street

Ottawa ON K1A ON4

Canada
Bibliothèque et

Archives Canada

Direction du

Patrimoine de l'édition

395 , rue Wellington

Ottawa ON K1A ON4

Canada
Your file Votre référence

ISBN: 978-0-494-93524-8

Our file Notre référence

ISBN: $978-0-494-93524-8$
NOTICE:

The author has granted a nonexclusive license allowing Library and Archives Canada to reproduce, publish, archive, preserve, conserve, communicate to the public by telecommunication or on the Internet, loan, distrbute and sell theses worldwide, for commercial or noncommercial purposes, in microform, paper, electronic and/or any other formats.

The author retains copyright ownership and moral rights in this thesis. Neither the thesis nor substantial extracts from it may be printed or otherwise reproduced without the author's permission.
AVIS:

L'auteur a accordé une licence non exclusive permettant à la Bibliothèque et Archives Canada de reproduire, publier, archiver, sauvegarder, conserver, transmettre au public par télécommunication ou par l'Internet, prêter, distribuer et vendre des thèses partout dans le monde, à des fins commerciales ou autres, sur support microforme, papier, électronique et/ou autres formats.

L'auteur conserve la propriété du droit d'auteur et des droits moraux qui protege cette thèse. $\mathrm{Ni}$ la thèse ni des extraits substantiels de celle-ci ne doivent être imprimés ou autrement reproduits sans son autorisation.
In compliance with the Canadian Privacy Act some supporting forms may have been removed from this thesis.

While these forms may be included in the document page count, their removal does not represent any loss of content from the thesis.
Conformément à la loi canadienne sur la protection de la vie privée, quelques formulaires secondaires ont été enlevés de cette thèse.

Bien que ces formulaires aient inclus dans la pagination, il n'y aura aucun contenu manquant. 


\section{Abstract}

Architecture can contribute to health and healing through viewing the site, street, neighborhood and city as an analogy to the body. To design for the body is to design for the city and vice versa. This thesis examines how architecture and the built environment can affect people's health. It analyzes how people interpret environmental stimuli through the senses. Acupuncture, a traditional Chinese medicine technique, is studied and developed as an approach to address architectural and urban issues. Three cases studies, Paimio Sanatorium, Maggie`s Centre and Stephen Avenue, are examined as precedent for the thesis project. The thesis project is a series of architectural projects along Ottawa's Chinatown. The projects are designed to assist in revitalizing the area and to improve the lives of the inhabitants and the neighborhood. 


\section{Acknowledgements}

Thank you to my advisor Steven Fai for his support, guidance and editing.

Thank you to Marco Fracscari, Greg Andonian, Roger Connah, the faculty and staff at Azrieli School of Architecture \& Urbanism.

Thank you to my sister for her editing and thank you to my family for their support. 


\section{Table of Contents}

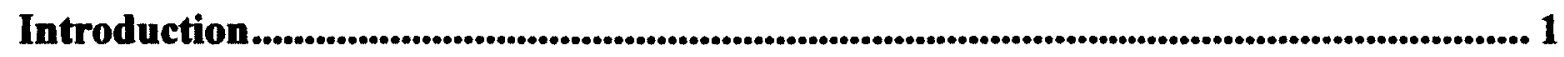

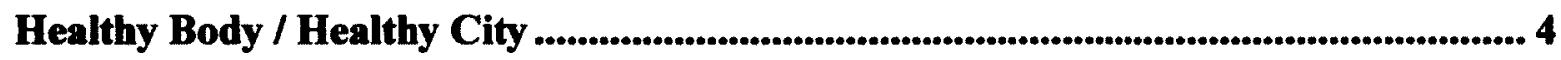

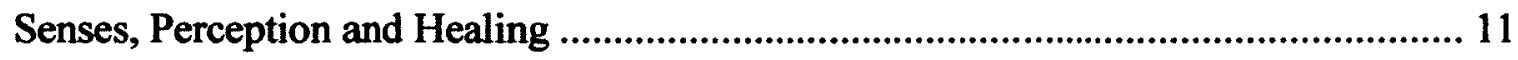

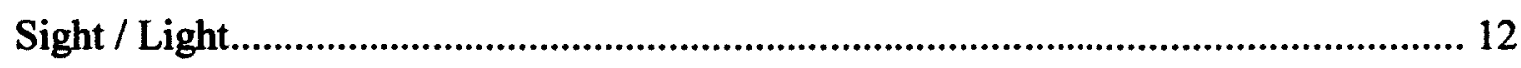

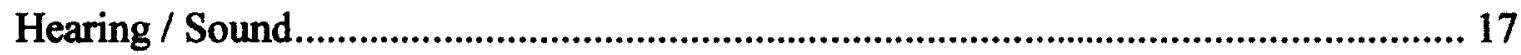

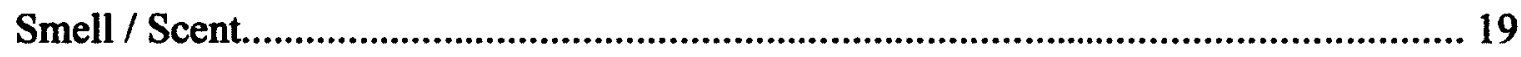

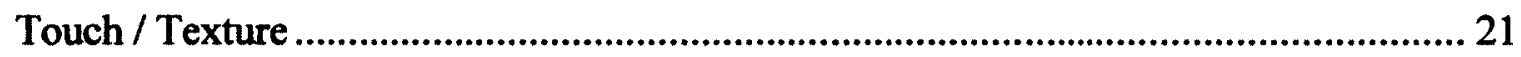

Medicine \& Architecture................................................................................... 24

Traditional Medicine and Contemporary Architecture ......................................... 24

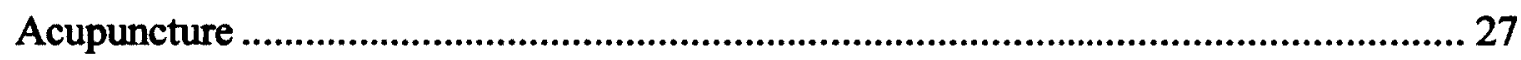

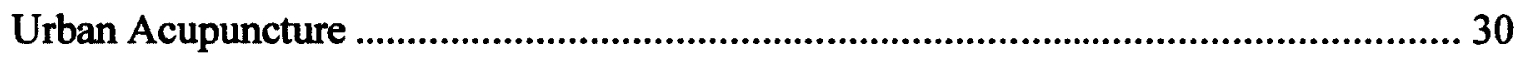

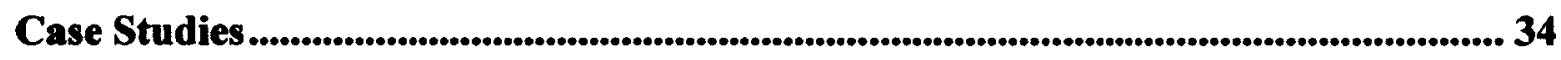

Tuberculosis Sanatorium at Paimio by Alvar Aalto, 1929-1933 ............................. 34

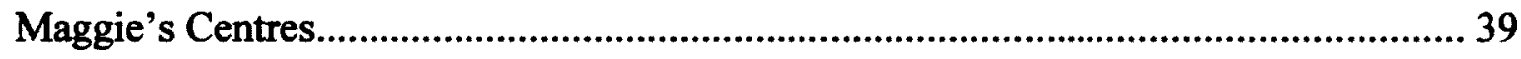

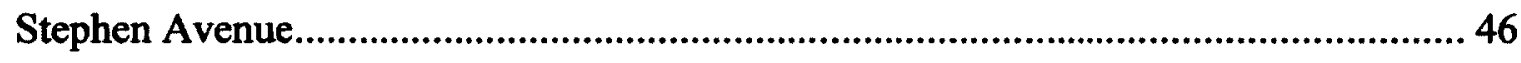

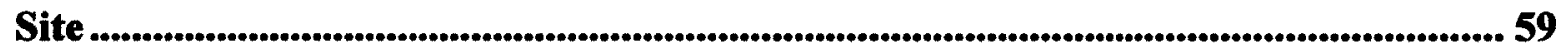

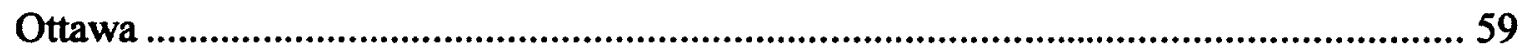

Brief History of Chinese Immigration into Canada and Ottawa's Chinatown ............ 62

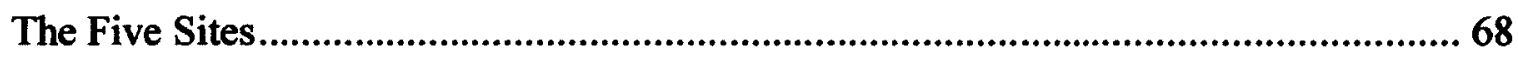

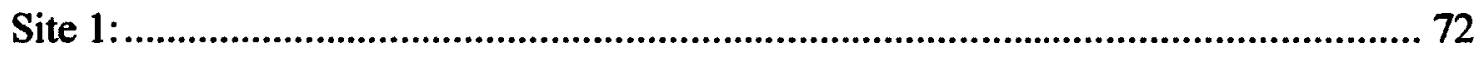

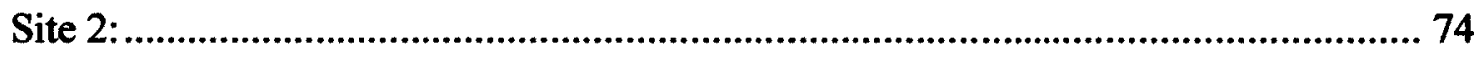

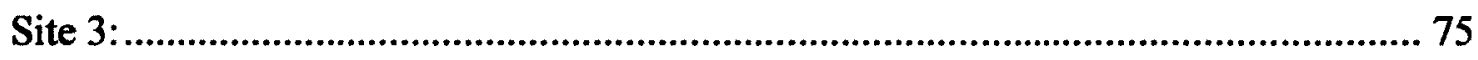

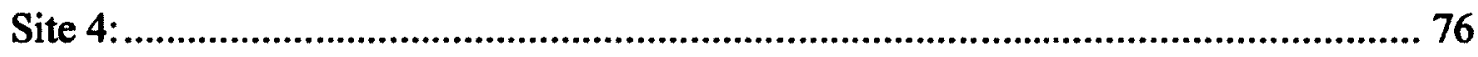

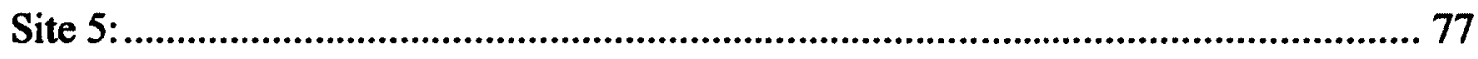

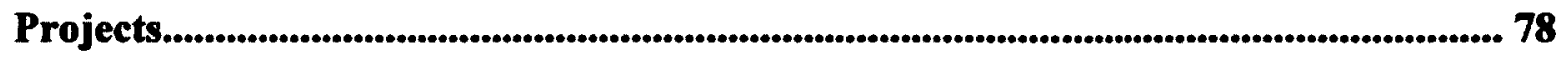

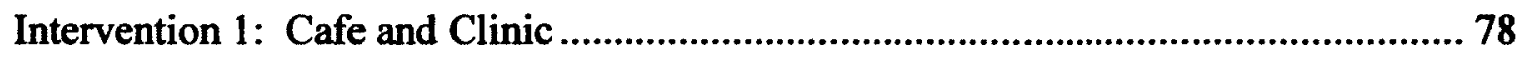

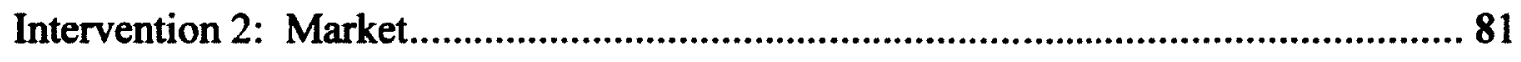

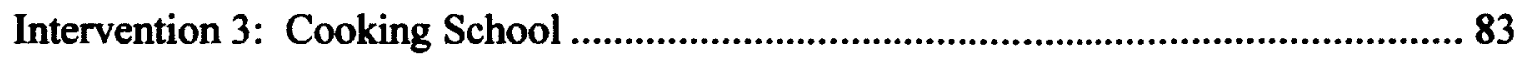




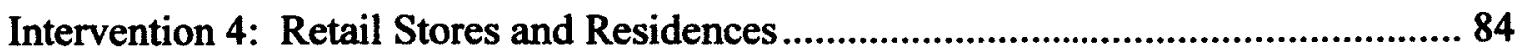

Intervention 5: Gallery Space / Community Centre ........................................................ 85

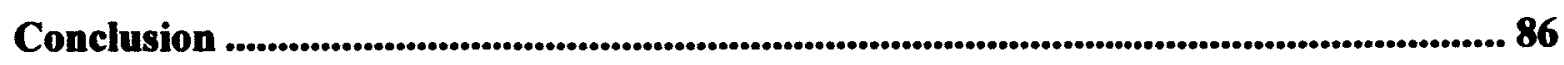

Appendix: Plans, Sections, Elevations \& Structure.................................................................. 88

Bibliography ...................................................................................................................................... 100 


\section{List of Illustrations}

Figure 1 - Paimio Tuberculosis Sanatorium - Ground plan of the main building. ........... 35 Figure 2 - Paimio Tuberculosis Sanatorium - Patients' washbasins, and conical light-

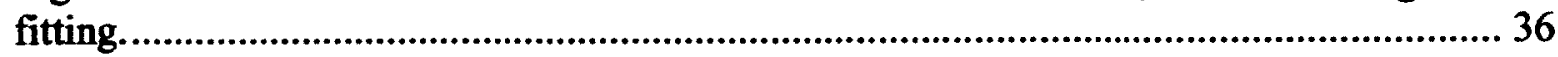

Figure 3 - Kitchen area of Maggie's Cheltenham......................................................... 41

Figure 4 - Dundee Maggie's Centre.................................................................................... 43

Figure 5 - Photograph of Stephen Avenue......................................................................... 47

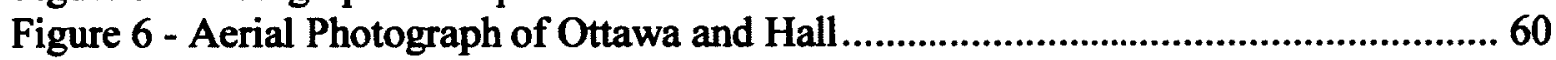

Figure 7 - Aerial Photography of Ottawa Chinatown along Somerset Street.................... 67

Figure 8 - Aerial Photography of Project Area in Ottawa Chinatown............................... 70

Figure 9 - Site Plan with Building Types........................................................................ 71

Figure 10 - North Street Elevation of Somerset Street between Preston and Rochester .. 71

Figure 11 - South Street Elevation of Somerset Street between Preston and Rochester .. 71

Figure 12 - Site 1 ....................................................................................................... 72

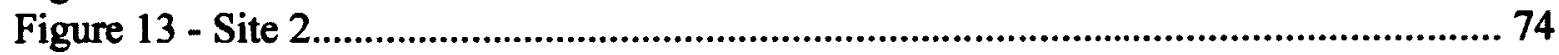

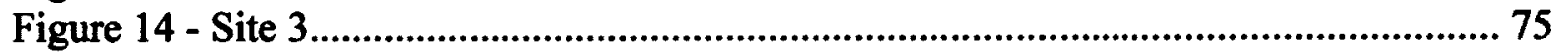

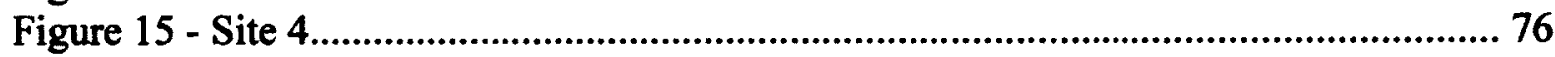

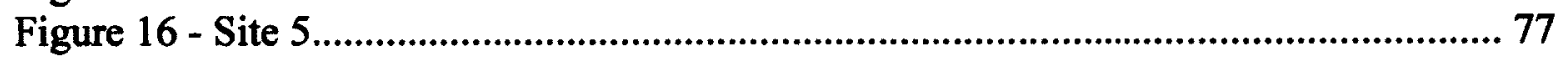

Figure 17 - Cafe \& Physiotherapy Clinic ........................................................................ 78

Figure 18 - Market ……................................................................................................ 81

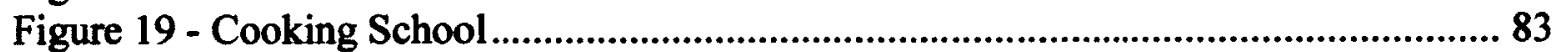

Figure 20 - Commercial and Residential Units.............................................................. 84

Figure 21 - Gallery Space / Community Centre ................................................................. 85

Figure 22 - North-East View of Somerset Street Model....................................................... 88

Figure 23 - North-West View of Somerset Street Model ................................................... 88

Figure 24 - South-West View of Somerset Street Model ........................................................ 89

Figure 25 - South-East View of Somerset Street Model...................................................... 89

Figure 26 - South-East View of Cafe \& Clinic................................................................... 90

Figure 27 - North-East View of Cafe \& Clinic ............................................................ 90

Figure 28 - South Elevation Cafe \& Clinic....................................................................... 91

Figure 29 -West Elevation of Cafe \& Clinic ...................................................................... 91

Figure 30 - North Elevation of Cafe \& Clinic .................................................................. 92

Figure 31 - East Elevation of Cafe \& Clinic ...................................................................... 92

Figure 32 - Interior View of Market …..................................................................... 93

Figure 33 - South Elevation of Market ............................................................................... 93

Figure 34 - East Elevation of Market................................................................................. 94

Figure 35 - Section of Cafe \& Clinic .............................................................................. 94

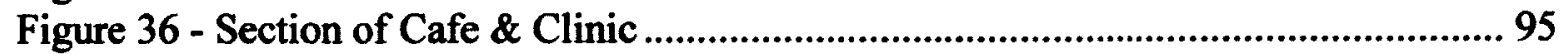

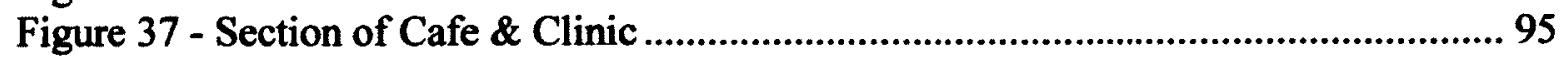

Figure 38 - Structure of Cafe \& Clinic .............................................................................. 96

Figure 39 - Ground Floor Plan of Cafe \& Clinic ............................................................... 97

Figure 40 - Second Floor Plan of Cafe \& Clinic ................................................................ 98

Figure 41 - Third Floor of Cafe \& Clinic …….................................................................. 99 


\section{Introduction}

A key topic of this thesis is people's health and their relationship to the built environment. It is about discovering to what extent our surroundings, buildings and constructed landscapes can affect our bodies and mind.

The second topic of study in this thesis is about how we can use our understanding of medicine and medical techniques as an analogy to analyze architectural issues and propose solutions. The particular area of focus is looking at the city, street and building as analogy to the human body and how individual parts are interconnected to the whole and to each other.

The question that arises is that of how can architecture can affect our health? Can it even affect it at all and if so, then how? Can architecture influence a specific behaviour or reaction from its inhabitants? There are various responses to those questions, ranging from the stance that the individual health is determined by and unto themselves and that the environment have no effect on them, to the stance that architecture can have a great effect on a person's health. This thesis takes the position that architecture can enhance the possibility that certain response can happen but cannot control it. Architecture can indirectly influence health.

This thesis will first examine existing ideas on the relationship between architecture, health and the body. It will then study existing analogies of the body and medicine to 
develop an approach to designing architecture and the urban environment. It will use case studies to provide precedent and support for the position. Finally it will examine a site, find the issues and develop a response to it in the form of architectural projects.

This thesis is divided into five major sections.

The first section is on health and the built environment. It explains how the built environment, primarily architecture, affects our health. It then examines how we perceive the environment with the physical stimuli of light, sound, scent and texture by our senses of sight, hearing, smell and touch.

The second section looks at medicine and how specific medical theories and ideas can be used as an analogy to resolve architectural and urban design issues. Prognosis and in Hippocratic medicine is explained and defined. Prognosis is then interpreted as a way to examine architectural issues and to develop an architectural proposal. A brief explanation of acupuncture in Traditional Chinese medicine is provided to give a conceptual basis for Urban Acupuncture. Urban Acupuncture is a method that uses acupuncture as a metaphor to initiate changes in the city in form of interventions. Two existing practices of Urban Acupuncture are explained and an approach of architectural interventions is developed to be used in the project section of this thesis.

The third section contains three case studies examining two projects associated with health and a third project related to the condition of the urban environment and street. 
The history and development of the projects are described and critically analyzed. The three projects are the Tuberculosis Sanatorium in Paimio by Alvar Alto, the Maggie Centres in the United Kingdom and Steven Avenue in Calgary, Alberta.

The fourth section analyzes Ottawa's Chinatown. The site for the project is Somerset Street between Preston Street and Rochester Street, which is located in Ottawa's Chinatown. The history of Chinese immigration and the development of Ottawa's Chinatown are explained. The current state of Chinatown is examined. Five sites are then chosen for five different architectural interventions.

The fifth section describes the five architecture projects on the five sites and provides illustrations on each. The main project is a cafe and clinic and the secondary project is a market. Those two projects are fully developed while the remaining three are in the form of proposals for potential use of the sites.

This thesis concludes with summation and an appendix with additional images, plans and sections of the projects. 


\section{Healthy Body / Healthy City}

The World Health Organization defines health as "... a state of complete physical, mental and social well-being and not merely the absence of disease or infirmity."1 In other words, to be healthy is not simply to be free of a past or current affliction - it is the anticipation of the ongoing and future well-being of the body. While this characterization of the healthy body is consistent with both traditional Chinese medicine and Hippocratic medicine practised in the West before the 17th century, it is very much at odds with medicine as it is generally practiced in today in Europe and North America.

Western medicine has been widely criticized, even by practitioners. For example, in a report on the psychological and social needs of patients, the British Medical Association (BMA) states that:

The traditional model of healthcare is a medical model, focusing on the history of illness, investigation into the physiological basis of symptoms, and remedies to return those to normal, followed by measurement of outcomes. The broader wellbeing of the person experiencing illness, and being a patient often for the first time, can be lost within this model.

\footnotetext{
' Preamble to the Constitution of the World Health Organization as adopted by the International Health Conference, New York, 19 June - 22 July 1946; signed on 22 July 1946 by the representatives of 61 States (Official Records of the World Health Organization, no. 2, p. 100) and entered into force on 7 April 1948. World Health Organization 2011. Web. <http://www.who.int/suggestions/faq/en/index.html>, 26 
This overly mechanistic view has been recognized for decades as having defects.

In general practice in particular Balint and others have described a different approach which considers the patient first as a person, within their family, community and workplace. Known often as a holistic approach this merges readily in modern views of patient-centred care, and of patients as partners in their care. Beyond all this is an additional element; people who become unwell have needs that are social and psychological. Meeting those needs will improve their health and aid recovery. There is a developing evidence base[d] on the psychosocial, and physical cost of not meeting these needs, and on the positive effects of changing the way in which we care, and the environment in which we offer care. $^{2}$

The BMA further states in the report that "helping an ill person back to better health requires due account to be taken of factors other than their physiology and anatomy; meeting psychological, social, spiritual and environmental needs are important." ${ }^{3}$ The report elaborates on how to improve the care and recovery of the patients through training and education of medical staff to better communicate and meet the patient's physiological and social needs. It also lists examples of art, humanities and social activities that the patients can participate in. The report recognizes the role that the physical environment

\footnotetext{
${ }^{2}$ British Medical Association. The Psychological and Social Needs of Patients. BMA Science \& Education. British Medical Association. London, 2011. Web. 2012 May 26. $<\mathrm{http}: / /$ www.bma.org.uk/images/psychologicalsocialneedsofpatients_tcm41-202964.pdf>, 1

${ }^{3}$ Ibid. 1.
} 
has on healing. A poorly designed environment can be detrimental to the health of the patients, while a well designed physical environment can be psychologically supportive. ${ }^{4}$

It is my thesis that the city can, in and of itself, be understood as a kind of body comprised of "organs", structures, and flows of material and energy that, while somewhat distinct in their function, are part of an interdependent system. Further, I would like to suggest that the human body is part of this city/body. Therefore, to design for the human body is to design for the city and vice versa. By way of analogy, traditional medical treatments, such as acupuncture, that are used on the human body may also be understood as effective for treating unhealthy conditions within the city.

In her book, Healing Spaces, Esther M. Sternberg argues that our physical environment affects our health and healing. She explains how our body and mind reacts to our surroundings and how our reactions in turn affect the healing process. She supports her explanations with research done in the scientific community about the interaction between environment and healing. The main topics she discusses are the senses (particularly that of sight, hearing, smell and touch), emotions, memory, body and hormones, and perception. She provides an understanding of how our body and mind respond to the environment and how it can enable us to create better healing spaces. The

\footnotetext{
${ }^{4}$ Ibid. 5-14.
} 
author's purpose, when framed in an architectural perspective, is to explain how architecture and our environment can help healing. ${ }^{5}$

Following Sternberg's argument, the physical environment can support our health and healing by relieving psychological stresses and being attuned to our physiological responses. Stress is detrimental to health because "it slows down healing, predisposes the body to more severe and more frequent infections, and compounds the effects of illness." Stress triggers the body to react in a certain way, releasing hormones such as adrenaline and shutting down the digestive system (i.e. the fight or flight response). This response can sometimes be beneficial when we need to act quickly. However, a stress response to a non-life threating situations or a constant stress can be detrimental to a person's health. Stress can also be caused by memory association and emotional reaction to a place (e.g. a place that one associates with trauma). A stress response can also be elicited by the physical environment. An adverse environment with extreme temperatures, disturbing noises, harsh or no lighting can also affect physical stress. ${ }^{7}$

In addition to psychological stress, the release of toxic chemicals from building materials and the construction process can also be detrimental to human health. Off-gassing and particulates from adhesives, paints, and insulation can cause allergic reactions or may be carcinogenic.

\footnotetext{
${ }^{3}$ Sternberg, Esther M. Healing Spaces: The Science of Place and Well-Being. Cambridge, Massachusetts: Belknap Press of Harvard University Press, 2009. Print.

${ }^{6}$ Ibid. 226.

${ }^{7}$ Ibid. 226-227.
} 
How can an environment participate in the healing process? First, a healing environment is necessarily one where both negative psychological and physiological factors are mitigated. ${ }^{8}$ Mary Jo Kreitzer, a registered nurse and professor at the University of Minnesota, states that we need and seek out safety and security as well as physical and physiological comfort in the environment. She explains how the environment can affect people by creating spaces that encourages social interaction or affect mood (e.g. bright natural light reduces the effect of depression). She states that there are five areas in which hospitals can reduce stress: through increasing the patients contact with nature through views of nature of access to gardens; give the patient the ability to control their surroundings and provide options so that they may feel empowered; provide social support by having patients' friends and family visit and providing them comfortable furniture; reduce physical stress created by the environment, such as noises and bad air quality, through the design of the building and environmental control systems; and finally, offer diversions such as nature or images of nature to keep patients' thoughts away from pain. ${ }^{9}$

Sternberg suggests:

That if architects, neuroscientists and psychologists] could understand how physical surroundings affect emotions and how emotional response to architecture

\footnotetext{
${ }^{8}$ Ibid. 226-227.

9 Kreitzer, Mary Jo. What Impact Does the Environment Hove on Us? Taking Charge of Your Health. University of Minnesota. February 2009. Web. 29 March 2012. $<$ http:/ttakingcharge.csh.umn.edu/explore-healing-practices/healing-environment/what-impact-doesenvironment-have-us>
} 
affect people's health, then people's health could be taken into account in the design of the building. Perhaps architects might even have some objective ammunition when trying to convince clients to spend a little more on larger windows and natural settings. Perhaps 'green' design would turn out to be as beneficial to individuals' health as it is to the planet's health. ${ }^{10}$

It is often difficult to convince a client of architecture of the intangible benefits of designing a healthy space. While quantifiable measures like return on investment or energy efficiency are more generally understood as adding value, it is difficult to define or measure qualities like happiness and long term health benefits. Happiness is subjective and there are many factors that affect the health of a person in a building. Neuroscientists, medical organizations and government agencies are working on developing ways to understand the interaction between the built environment and people's health. ${ }^{11}$ The research, studies and reports done on healing and the environment may provide the additional support we need to build healthier places.

Sternberg asks the question: "When did the focus change from the patients to the disease, from healing to diagnosing and treating?"12 She states that it happened when medicine started to use modern technological equipment for diagnosis, such as $\mathrm{x}$-ray machines. The design of hospitals became more accommodating to the maintenance of medical equipment and less towards the patient. As more modern equipment is placed in the

\footnotetext{
${ }^{10}$ Sternberg, Esther M. Healing Spaces: The Science of Place and Well-Being. 2009. 7.

11 Ibid. 294-295.

12 Ibid. 4.
} 
hospital the priorities of the patients comfort and surroundings are reduced. ${ }^{13}$ The space requirement of the medical equipment required a larger hospital which resulted in longer and more disorienting halls. ${ }^{14}$ Sanitation of the hospital requires hard non-porous materials, such as metal or tile, which are acoustically reflective; creating a noisy environment that disturbs the patient. ${ }^{15}$ These two reasons, along with other factors create a stressful experience for the patient. The priorities of the hospital went from being patient-focused to being disease-focused.

Sternberg concludes her book by stating that "the most powerful of healing places is in the brain and mind." 16 Our perspective and state of mind is an important factor in determining our health. Furthermore, while the built environment cannot determine completely what happens in someone's life, it can be designed to mitigate stress and contribute to healthy life.

\footnotetext{
${ }^{13}$ Ibid. $3-4$.

${ }^{14}$ Ibid. 226-227.

${ }^{15}$ Ibid. 219.

${ }^{16}$ Ibid. 296.
} 


\section{Senses, Perception and Healing}

Our perception of spatial phenomena triggers biochemical responses in our bodies. These biochemical responses are also implicated in the health of the body and in the mitigation of disease. Sternberg uses this inter-relationship as the basis for her argument on the influence that the physical environment has on our physical well-being. ${ }^{17}$

Following Sternberg, our experience of the world is multi-sensual and our sensual experiences affect our overall wellbeing as individuals and collectively as citizens.

The following sections explore how physical stimuli are received by the senses and perceived by the mind through memory, emotions and imagination. The senses are paired with phenomena most closely associated with them: sight-light, hearing-sound, smell-scent and touch-texture. Each section starts with a narrative of an experience with the sense and we will discuss how the stimuli, our sense and our perception of the environment affect our healing and health.

${ }^{17}$ Ibid. 21. 


\section{Sight / Light}

I walk through the busy streets of the city of in the night, full of people, signs, cars, signs and buildings illuminated from within. As I approach the theater from the outside I see the patrons gathering and moving around in the lobby. The closer I get, the more I see, the more detailed and larger they become; from their body shape, to the clothes they are wearing, to the expression on their faces and the color of their eyes. I follow them as they gather in the glowing, warm yellow light of the lobby. Then I enter the dim floor, illuminated theater space. The audience and I sit as the light softens ever further and the chatter quiets. My eyes are drawn towards the stage. The red velvet curtains, trimmed with gold tassels, slowly part. The stage is dark and barren except for a few props. The dancers move onto the stage, their bodies illuminated from the side stage light emphasizing, their movement in their dance and their figure. Their movement express emotions such as passion, happiness, sadness and anger. The dancers interact with the minimalist props and stage sets while my imagination fills in the rest. The story is told without speech. It is instead expressed through dance, movement and sound. The story ends and the curtain closing, bringing my attention back from the world of the stage back to the surrounding auditorium. As I leave the theater and make my home, images of the performance are recollected from my memory.

There are three phases in the process of seeing: the physical stimuli of light, the eyes receiving the stimuli and the brain interpreting the signal from the eyes. When we look at an object, light waves from a light source hit an object and those waves are reflected into 
our eyes. Sternberg explains that when light enters our eyes it hits the retina and triggers an electrical signal that is sent to the brain. The brain receives multiple signals from the eyes, each comprised of a part of the image. The image is then assembled in the brain and the whole image is related to others in our memory. When the brain finds a close matching image, we recognize what the image is. ${ }^{18}$

It is important to recognize the difference between visual information and visual perception. Visual information is the light reflecting or emitting from an object. Our field of vision is more horizontal than vertical; we see and engage in activities on a horizontal field. ${ }^{19}$ Thus placing activities on only one level, such as the street level, instead of separating it on multiple levels gives people better opportunity for people meet each other as well as to engage in social activities. Variances in the distance between us, the environment and other people change the character of a space. In small spaces we can engage with other people and see the details. ${ }^{20}$ In large, open and empty spaces we can feel cold and detached. ${ }^{21}$ Visual perception is the brain's interpretation of the image from the eyes. Perception of an image is constructed by the brain and from our memory and is dependent on the individual. The built environment cannot change visual perception but it can change the visual information around us by changing the physical space and thus changing what could be perceived. It can also change the quantity,

\footnotetext{
${ }^{18}$ Ibid. 27-28.

${ }^{19}$ Gehl, Jan. Life Between Buildings: Using Public Space. $6^{\text {th }}$ Edition. Copenhagen: The Danish Architectural Press, 2006. Print. 63.

${ }^{20}$ Ibid. 68.

${ }^{21}$ Ibid. 68 .
} 
quality and shape of the light around us. This is where we, as architects, can influence what people see, and in turn, affect the health of both individuals and the collective.

The warm bright sun of the afternoon falls on me and on the landscape around me as I sit in front of the emerald green lake. The views of the lake are framed by two tree covered mountains on both side and another in the back. The icy cold water flows from the glacier and snow covered mountains at the mouth of the lake. The beautiful vista leaves me relaxed and refreshed.

Roger Ulrich, the Director of the Center for Health Systems and Designs at Texas A\&M University argues that gardens and nature have a positive effect on health. Part of our perception of nature involves our sense of vision. Ulrich observes that the sight of nature and plants can reduce stress and improve health recovery. He reports that views of nature increase positive emotions such as calmness and reduce negative emotions such as sadness. The physiological response from reducing stress lowered blood pressure and decrease muscle tension. His claims are supported with multiple studies and experiments done by him and other researchers. ${ }^{22}$

Ulrich discusses a study on patients in a hospital room with and without a view of nature. The patients with a window facing trees recovered more quickly and required fewer pain

\footnotetext{
${ }^{22}$ Ulrich, Roger S. Health Benefits of Garden in Hospitals. Plants for People, International Exhibition Floriade, 2002. Web. 31 March 2012.

$<\mathrm{http} / /$ greenplantsforgreenbuildings.org/attachments/contentmanagers/25/HealthSettingsUlrich.pdf>. 3-4.
} 
medication then the patients with a view of a brick wall. ${ }^{23}$ Sternberg reports a study where patients in a hospital ward were placed in two different rooms, one with sunlight and the other with low light. The patients staying in the brighter room were released from the hospital several days earlier than the other group. ${ }^{24}$

Sunlight plays an important role in healing. It can affect both psychology and physiology. Some people are negatively affected by the lack of sunlight during the winter months and those who are particularly sensitive to this can have a form of depression called Seasonal Affective Disorder (SAD). SAD is caused by a reduced exposure to sunlight during the winter months. ${ }^{25}$ Treatment for this disorder can be achieved through increasing exposure to daylight, exercise or light therapy with a lamp that simulates sunlight. ${ }^{26}$ Sunlight helps the body generate vitamin $D$, which necessary for absorption of calcium in our bones. ${ }^{27}$ The ultra violet light from the sun hits the skin and vitamin $\mathrm{D}$ is created by the body. ${ }^{28}$

Culturally, in the west, sight has been privileged above the other senses. This is discussed by Juhani Pallasmaa in his book, Eyes of the Skin (2005). He argues that our technological culture has segregated our senses, assigning vision the highest value and

\footnotetext{
${ }^{23}$ Ulrich, R. S. "View through a window may influence recovery from surgery". Science, 224 (4647), 1984: 420-421. Web. 29 March 2012. <http://www.jstor.org/stable/1692984?origin=JSTOR-pdf>

${ }^{24}$ Sternberg, Esther M. Healing Spaces: The Science of Place and Well-Being. 2009. 49-50.

${ }^{25}$ Seasonal affective disorder. A.D.A.M. Medical Encyclopedia. U.S. National Library of Medicine. A.D.A.M., Inc. 2012. Web. 31 March 2012. <http://www.ncbi.nlm.nih.gov/pubmedhealth/PMH0002499/>

${ }^{26}$ Seasonal affective disorder. A.D.A.M. Medical Encyclopedia. U.S. National Library of Medicine. A.D.A.M., Inc. 2012. Web. 31 March 2012. $<$ http://www.ncbi.nlm.nih.gov/pubmedhealth/PMH0002499/>

${ }^{27}$ Stemberg, Esther M. Healing Spaces: The Science of Place and Well-Being. 2009. 51.

${ }^{28}$ Ibid. 51.
} 
supressing the other senses. ${ }^{29}$ He states that "[t]he dominance of the eye and the suppression of the other senses tends to push us into detachment, isolation and exteriority."30 This is evident in the prevalence online communities that use videos, images and text as the major form of communication. These virtual communities may distance people from reality and reduce their contact with physical world. People need social contact and the engagement of the other senses to truly feel connected their environment and to others.

${ }^{29}$ Pallasmaa, Juhani. The Eyes of the Skin: Architecture and the Senses. Hoboken, NJ: Jon Wiley \& Sons, 2005. Print. 16.

${ }^{30}$ Ibid. 19. 


\section{Hearing / Sound}

Many of my extended family gatherings happened in the late weekend mornings, over tea and dim sum, in a Chinatown restaurant. Having dim sum is more than just having food, it is also about meeting, having a conversation and sharing stories with friends and family. Often, when I arrive with my family at a restaurant it is full and we have to wait for a table to become available. As I wait, I hear the indiscernible chatter of the many people conversing in multiple languages. Their voices are mixing together and bouncing off the surfaces of the room and into the hallway. I hear the waitress yelling out the names of dishes in Cantonese. A table finally becomes available, so the hostess guides us to it through a grid of tables, full of parents, children and grandparents, talking and laughing around us. We sit at a circular table covered in white table cloth with dishware and chopsticks. This circular table allows for easy conversation among us. As we sit and eat delicious dim sum, we talk about the events and stories of our lives. I hear the clank and clink of the porcelain dishes clashing into each other and the chopsticks when we eat. The room is big and open, allowing sound to travel across the room. Sometimes I have to speak up to be heard. It is not unpleasant, we can be heard, but some of the sounds are absorbed by the soft surfaces in the restaurant. The auditory experience of the space creates an acoustical memory. When I relive the experience through my memory, I remember not only the images, scents and flavours but also the sounds and the conversations that had occurred. 
Our built environment has an acoustic character; spaces have specific and recognizable acoustical characteristics that we identify with the space. Juhani Pallasmaa has recognized this phenomenon, space is perceived acoustically as well as visually. ${ }^{31}$ When we remember specific spaces such as a concert hall, a museum, a library or a park, we recognize the space first visually and then we perceive its sound quality as we move closer. For example, we will notice a difference in the sounds of a museum, a park or busy city street.

Pallasmaa also argues that silence is an important part of the experience of architecture ${ }^{32}$. He states that that "[a] powerful architectural experience silences all external noise; it focuses our attention on our very existence, and as will all art, it makes us aware of our fundamental solitude"33. Silence lets us be aware of our own being by removing the auditory distraction around us. It allows us to reflect, to contemplate about life.

When Architects design a space they should consider how the auditory qualities of that space will affect the inhabitants. This means paying attention to geometry and materiality. Sound can affect people through both a presence and an absence. Music can trigger memories. Silence can be calming.

\footnotetext{
${ }^{31}$ Pallasmaa, Juhani. The Eyes of the Skin: Architecture and the Senses. 2005. 50.

${ }^{32}$ Ibid. 51.

${ }^{33}$ Ibid. 52.
} 


\section{Smell / Scent}

When I enter a Chinese bakery, I smell the sweet scent of freshly baked buns, cakes and rolls; baked pineapple buns with sweet golden crumbly crust; aromatic sweet egg tarts cooling off fresh from the ovens; steamed buns with roast pork and onions coated in a red sticky sweet and savoury sauce; all mixing together yet each having a distinct moment in my awareness. The rush of the aroma from the food, as I open the door to the bakery, awakens my appetite and brings back memories and emotions of my past and childhood. I remember the delight and anticipation of my parents telling me, "we were going to the bakery". I remember the excitement and sensations I felt when opening each shelf to pick a bun and having its strong aroma rush into my nostrils. I remember the bun's sweet and moist savoury flavours as I put it in my mouth. The smell and the scent elicit memories of satisfaction, happiness and comfort from a time in the past. Interestingly, I can remember the scent of the buns as I write about my memory of the bakery. It feels brief and fleeting; the smell of the buns comes into nostrils in a breath and exit as I imagine it. The scent leaves a quickly as it comes, as does the accompanying memories and emotions.

There is a fruit called durian that is from South-East Asia. It is encased in a hard green husk covered with sharp thorns. The fruit inside is made up of soft edible yellow bulbs. A very pungent and distinctive odor arising from cracking open the outer husk of a ripened durian and exposing its bulbs. Some people say it is stinks, smells rotten and the odour offensive. Yet other people say it is fragrant and smells good. The response 
depends on a person's experience with the fruit. If a person grew up in a country where the fruit is grows, have been exposed to it early in their life and have enjoyed eating it, then they will likely appreciate it. If they haven't been exposed to it, the smell is offensive to them. Memories predispose people to respond to scents in a certain way.

It has been demonstrated that scents in can affect our health. Sternberg reports that studies have shown that scent has an effect on people's mood, brain activity and the regulation of hormones. However, Sternberg makes clear that the studies are based on a very small sample. ${ }^{34}$ Sternberg points out that that scent are used in aromatherapy to treat illness. She states that certain scented oils, infused, for example, with lavender or chamomile oil, are known to relax the mind or act as a sedative. Sternberg also reports that scents "are powerful at triggering memories." 35 Acknowledging studies that suggest scent is very much dependent on memory, she argues further that we associate certain scents with specific memories and emotions. ${ }^{36}$

\footnotetext{
${ }^{34}$ Stemberg, Esther M. Healing Spaces: The Science of Place and Well-Being. 2009. 87.

${ }^{35}$ Ibid. 88.

${ }^{36}$ Ibid. 89.
} 


\section{Touch / Texture}

When I enter a building, I am first greeted by the door handle and its texture, its density and its temperature. My feet feel the various surfaces within the building; the hardness of the cold concrete, the smoothness of the tiles and the softness of the carpet. My skin feels the change from the cool air of the exterior to the warmth of the interior. I move freely in the space but yet my movements are guided by the arrangement of walls, openings and stairways of the building.

Touch is our most direct and intimate sense. It connects us to the physicality of the world through our skin, hands body and feet. We feel the texture of our skin, clothing and buildings. Our feet feel the ground we step on. We feel the temperature of what we touch. When we touch an object we feel its texture, density, weight, moisture and temperature.

Our sense of touch allows us the possibility of perceiving and altering our environment at the same time. The sense "engages in feeling and doing simultaneously." 37 When we touch our environment we can change it and it can respond to our touch. ${ }^{38}$ The other senses such as sight and hearing only perceive at a distance. ${ }^{39}$

${ }^{37}$ Bloomer, Kent C. and Charles W. Moore. Body, Memory, and Architecture. New Haven and London: Yale University Press, 1977. 35.

${ }^{38}$ Ibid. 34-35

${ }^{39}$ Ibid. 34-35 
Pallasmaa states that "[n]atural materials express their age and history, as well as the story of their origins and their history of human use. All matter exists in the continuum of time; the patina of wear adds the enriching experience of time to the materials of construction. ${ }^{, 40}$ The physical qualities and age of a material is seen and felt. We see the surface of the material and feel its texture with our skin. The abrasion of a surface can also be seen and touched. It is important to integrate the sense of touch and therefore textures into the experience of a piece of architecture. It gives us a physical connection to the world and in the case of wearing it is a reminder of the time and the previous presence of those before us.

How can we design a healthy environment for touch? We can design the surfaces where we contact the building, such as the floor and door handles to be comfortable and inviting. We can create furniture that is comfortable and ergonomic. The form and layout of a building can guide and encourage its occupant to move and interact with it in a certain way.

Interestingly there is a parallel difference between the philosophies of Chinese medicine and Western medicine when compared to architecture's empirical based and theoretical based design approaches. Architects partly rely on empirical evidence and personal experience to support their designs through inductive reasoning. Architects also use design theories and deductive reasoning to drive design decisions. The research and studies reported by Sternberg are evidence based and were meant to provide data to

\footnotetext{
${ }^{40}$ Pallasmaa, Juhani. The Eyes of the Skin: Architecture and the Senses. 2005. 31.
} 
support the design decisions for creating a healthy environment for healing. This is also seen in the architecture field with structural, environmental and economic analysis of building designs. The two approaches of empiricism and rationalism may seem contrary but if used together along analysis and treatment of the parts and of the whole system we may have a more balanced approach that provide a better resolution for and architectural and health related issues. 


\section{Medicine \& Architecture}

\section{Traditional Medicine and Contemporary Architecture}

Generally speaking, traditional western medicine, commonly practiced in Europe from the $4^{\text {th }}$ century $\mathrm{BCE}$ to the $17^{\text {th }}$ century $\mathrm{CE}$, focused on prognosis as a strategy for treatment. The patient was understood as part of the greater order of things rather than as an isolated individual. His/Her history and present context, along with the history and development of the disease were assessed in tandem in order to develop an appropriate treatment. Prognosis also involved the anticipated recovery from the illness. ${ }^{41}$ The physician needed to know the symptoms and cause of the disease as well as the patient's life history, environment, psychological state; in other words his/her "individual nature." $" 42$

This idea of prognosis is consistent with traditional Chinese medicine in that the physician observes the surface of body and interprets its signs. His or her medical knowledge is based on experience and observed evidence. The readings from the body, in the case of the pulse are subjective and metaphors are used to describe the feeling of the pulse. Different pulses felt at different locations relate to different parts of the body.

\footnotetext{
${ }^{41}$ Pagel, Walter. "Prognosis and Diagnosis: A Comparison of Ancient and Modern Medicine." Journal of the Warburg Institute, Vol. 2, No. 4 (Apr. 1939): 382-398. Web. < http://www.jstor.org/stable/750046> ${ }^{42}$ Ibid. 384-385.
} 
The reading of the pulse tells the practitioner the state of health of the patient and the condition of the internal organs. ${ }^{43}$

The central concept of Chinese medicine is Yin and Yang. Yin and Yang are the "forces of opposite polarities. ${ }^{, 44}$ The balance of Yin and Yang within the body is established with the flow of life energy called Qi. Qi sustains the body and travels through channels in the body called meridians. The flow of Qi balances the yin and yang and maintains good health. When there is imbalance or obstruction of the movement of Qi then illness or pain occurs. ${ }^{45}$

The flow of Qi is managed through acupuncture. Acupuncture is a Chinese medical practice that is used to change the flow of Qi and restore the balance Ying and Yang. Needles are inserted along points on the meridians on the body to change the flow of Qi. This relieves pain and balances Yin and Yang. The location of the needle insertion, the cause of the effect, and the location of the effect on the body are different. The separation between the location of the cause and effect is justified by the connection of the sites by the meridians. ${ }^{46}$

\footnotetext{
${ }^{43}$ Kuriyama, Shigehisa. The Expressiveness of the Body and the Divergence of Greek and Chinese Medicine. New York: Zone Books, 1999. Print.

${ }^{44}$ Filshie, Jacqueline and John W. Thompson. "8.2.9 Acupuncture." Oxford Textbook of Palliative Medicine. $3^{\text {rd }}$ Edition. Eds. Derek Doyle, Geoffrey Hanks, Nathan Cherny and Kenneth Calman. New York: Oxford University Press, 2005. 411.

${ }^{45}$ Allchin, Douglas. "Points East and West: Acupuncture and Comparative Philosophy of Science". Philosophy of Science, Vol. 63, Supplement. Proceedings of the 1996 Biennial Meetings of the Philosophy of Science Association. Part I: Contributed Papers (Sep., 1996): S107-S115. The University of Chicago Press (on behalf of the Philosophy of Science Association). Web. 27 March 2012. $\langle$ http://www.jstor.org/stable/188517>. S109-S110. (summary from part of the source)

${ }^{46}$ Ibid. S107-100. (summary from part of the source)
} 
Returning to our analogy of the city as body, typically the analysis of architectural issues and design development are limited with the scope of the immediate context and in a relatively short time frame. It is focused on the present and immediate conditions of the site: they physical, programmatic, economic and ecological issues. This practice often results in unexpected concentrations or gaps in urban development that can have a widespread, negative influence on the city generally. If we image an urban acupuncture, the analysis of the site would be expanded to include the past, present and foreseeable future. For example, the history of the site and the surrounding area can be studied to discover what issues had confronted the residents and what their response was to those issues. This information, along with the present conditions of the area and the input from the residents, can be used to inform the development of the architectural response. Furthermore, by being aware of the past and present we can make a prediction on the future conditions of the area and create a design that will be flexible enough to meet the changing needs of the residents. 


\section{Acupuncture}

The two opposing forces of Yin and Yang is a central concept of Chinese medicine. The two forces are believed to exist in nature and inside the human body. ${ }^{47}$ Yang is a "male, positive, bright and warm" ${ }^{, 48}$ force and Yin is a "female, negative, dark and cold"49 force. The balance of Yin and Yang in the body is established with the flow of Qi. Qi is a life energy that sustains the body by travelling along meridians. ${ }^{50}$ Bowers explains that the meridians are channels on a separate network in the body that are independent from the nervous and circulation system. There are twelve major meridians that connect to the internal organs of the body. Pain or illness occurs when the flow of Qi is obstructed or imbalanced. $^{51}$

Allchin explains that acupuncture is a Chinese medicine practice where needles are used to regulate the flow of Qi and restore the balance between Yin and Yang. Solid slender needles are inserted into the skin of the body on points along the meridians. The insertion of needles causes a change in the flow of Qi balances the Yin and Yang in the body. The location the insertion point (the cause) and the location of the effect on the body are different and often distant. The site of cause and effect are connected through

\footnotetext{
${ }^{47}$ Bowers, John Z. “Acupuncture." Proceedings of the American Philosophical Society, Vol. 117, No. 3 (Jun. 15, 1973): 143-151. American Philosophical Society. Web. 15 May 2012. $<$ http://www.jstor.org/stable/986539>

${ }^{48}$ Ibid. 143.

${ }^{49}$ Ibid. 143.

${ }^{30}$ Allchin, Douglas. "Points East and West: Acupuncture and Comparative Philosophy of Science". Sep. 1996. S109-S110.

${ }^{51}$ Ibid. S109-S110.
} 
the meridians. The acupuncture points and meridians have been mapped out on the body. ${ }^{52}$

Allchin states that western medicine and science "cannot adequately explain why acupuncture points are where they are, nor how they relieve pain at distant locations." 53 There have been many attempts to scientifically explain how acupuncture works, but they have often been inadequate. ${ }^{54}$ However, this does not undermine the efficacy of acupuncture.

There are several key ideas to consider when imagining an urban acupuncture. First is the idea of inserting the needle into the meridians on the body to cause a larger effect. It is a minimally invasive technique used to relieve pain to heal illnesses. Secondly, is the idea of a distant relationship between the cause and effect. The site of insertion of the needle causes a remote effect at another part of the body through the control of Qi through the body. There is an interrelationship between the sites. Thirdly, is the idea that it is the balance between the Yin and the Yang in the body that maintains good health. Analogically, an urban acupuncture would use minimal interventions to relieve remote problems and restore the function of the city to normative parameters. A balance needs to be maintained between the activities, requirements and production of the interventions and inhabitants. This balance must consider the physical, social, cultural,

\footnotetext{
52 Ibid. S107-S111.

${ }^{53}$ Ibid. S109.

${ }^{54}$ Ibid. S019.
} 
economic and ecological imperatives of the city with the will of the architect, client, and builder. 


\section{Urban Acupuncture}

Jaime Lerner is an architect, an urban planner and the former mayor of Curitiba, Brazil.

He uses the term Urban Acupuncture as a method of creating quick changes to the city.

He defines urban acupunctures as:

Strategic, timely interventions can release new energy and help consolidate it [the project] toward the desired goals ... it revitalizes an 'ailing' or 'worn out' area and its surroundings through a simple touch in a key point. Just as in the medical procedure, this intervention will trigger positive chain reactions ... which will help to heal and enhance the whole system..$^{55}$

Many cities today need urban acupuncture because they have neglected their cultural identities; others because they have neglected their relationship with the natural environment; still others have turned their backs on the wounds left by economic activities. These neglected areas these "scar marks," are precisely the targets for the acupuncture. ${ }^{56}$

One of his urban acupuncture projects is a bus transportation system (BRT) in Curitiba that runs in its own dedicated lanes. One of the key features of the system is that people get on the buses by way of well designed transit stations or "boarding tubes" that increase

\footnotetext{
${ }^{55}$ Lerner, Jamie. "Reviving Cities." What We See: Advancing the Observation of Jane Jacobs. Eds. Stephen A. Goldsmith and Lynne Elizabeth. Oakland, CA: New Village Press, 2010. Print. 190

${ }^{\text {S6 Ibid. } 191 .}$
} 
service and efficiency to the same level as a subway. ${ }^{57}$ The BRT is integrated with other carrriers such as the taxi, bus and automobile that work together in a comprehensive system. ${ }^{58}$ The system reduces traffic congestion and makes the city more sustainable through the provision of an efficient mass transportation system. The BRT project is successful and analogous to acupuncture because it acknowledges the city as a system of interrelated parts and functions.

Another one of the urban acupuncture projects developed by Lerner is his "Portable Street." ${ }^{, 59}$ It consists of mobile street furniture that enables street vendors to setup in various locations in the city that needs more night life. It uses the same space that other shops opened during the day use, but at a different time. It takes place during a time where the street is unused at night. The two functions, of shops and street vendors, coexist together. The project was inspired by the Parisian bouquinistes. ${ }^{60}$ The bouquinistes are secured boxes used by booksellers to sell books along the bank of the river Seine in Paris.

A second theory of urban acupuncture has been developed by Manuel de Solà-Morales an architect and city planner in Barcelona, Spain. Solà-Morales uses the epidermis, the skin, as an analogy to the city. He describes the urban skin as "a qualitative network, a membrane of differences that are subject to interventions and strategies ... [and it] also

\footnotetext{
${ }^{37}$ Lerner, Jaime. Jamie Lerner Sings of the City. TED Conferences, LLC. March 2007. Video, Web. 25 March 2012. 〈http://www.ted.com/talks/jaime_lerner_sings_of_the_city.html>

${ }^{88}$ Lerner, Jamie. "Reviving Cities." What We See: Advancing the Öbservation of Jane Jacobs. 2010. 188189.

${ }^{59}$ Ibid. 187.

${ }^{60}$ Ibid. 187-188.
} 
channels qualitative energy. And if acupuncture speaks of 'cold' and 'hot' energy, the qualities of the urban epidermis are also blunt or sharp, mental or sensorial.".61

Solà-Morales states that “...[a]s in therapeutic acupuncture, [locating] the sensitive point is the first step in the strategic treatment of the urban skin. It is dexterity in the identification of the spot and the channels of influence in the fabric that enable us to add new qualities, adequate energy, whether cold or hot, and to empower urbanity in its various modes". ${ }^{62}$ The site is selected for its potential to influence the urban environment.

Solà-Morales argues that, like in acupuncture, the epidermis of the city is like the epidermis of the body, in that it is a system and that an action taken on one part of the body will have an effect on another part. ${ }^{63}$ He states that changes in energy through the skin cause changes in the body's interior. Interventions on the urban skin cause changes at a deeper level, in "abstract socio-economic, symbolico-cultural, infrastructural or historico-political terms. ${ }^{94}$ His urban acupuncture includes individual buildings, projects at an urban scale and are all concerned with the "strategic, the systemic and the interdependent." 65

\footnotetext{
${ }^{61}$ Solà-Morales, Manuel de, Kenneth Frampton and Hans Ibelings. A Matter of Things. Rotterdam: NAi Publishers, 2008. Print. 24.

62 Ibid. 24.

63 Ibid. 24-25.

64 Ibid. 25.

${ }^{65}$ Ibid. 24.
} 
Kenneth Frampton, architectural historian, explains Solà-Morales use of urban acupuncture as an intervention that enhances the city through boundaries and organization. The building acts as an apparatus that reorganizes and enhance its surroundings. Its presence encourages further development of the area around it. ${ }^{66}$

However, Solà-Morales' use of the acupuncture analogy has been criticized. Hans Ibelings argues that Solà-Morales' method is not an undeviating analogy to acupuncture. Where the cause and effect in acupuncture is located in different areas of the body, SolàMorales' interventions directly affect the immediate site area. Where acupuncture changes the flow of energy in the body, his interventions opens up the potential of the site. $^{67}$

${ }^{66}$ Ibid. 7.

${ }^{67}$ Ibelings, Hans. "The Architecture and Urban Design of Manuel de Solà-Morales." A Matter of Things. Manuel de Solà-Morales, Kenneth Frampton and Hans Ibelings. Rotterdam: NAi Publishers, 2008. Print. 11. 


\section{Case Studies}

\section{Tuberculosis Sanatorium at Paimio by Alvar Aalto, 1929-1933}

Tuberculosis is a bacterial infection of the lungs. According to the Canadian Lung Association, it is a disease that has been infecting people since antiquity. The disease can be fatal. Tuberculosis was first discovered to be an infectious disease in the $17^{\text {th }}$ century. The source of the infection, however, was not discovered until in the $19^{\text {th }}$ century, when Robert Koch identified the bacteria that caused of the disease. In the late $19^{\text {th }}$ century and early $20^{\text {th }}$, people with tuberculosis were sent to Sanatoriums - a building type designed specifically to isolate patients and to treat the disease with bed rest, fresh air, sunlight and good nutrition in order to let the body heal itself. It was not until the discovery of a drug treatment in the 1950's that there was an effective cure. ${ }^{68}$

The Tuberculosis Sanatorium at Paimio was designed by Alvar Aalto in 1928 and was constructed between 1929 and 1933 . The design was a direct response to the contemporary treatment for tuberculosis, including daily exposure to sunlight and fresh air. ${ }^{69}$

The Paimio Sanatorium was is divided into three sections: a patient ward, commons rooms and technical and service rooms. The physicians' and employees' houses were

${ }^{68}$ Canada's Role in Fighting Tuberculosis, Yesterday, Today and Tomorrow. Canada's Digital Collections program, Industry Canada. Canada Lung Association. Web. 13 April 2012. < http://www.lung.ca/tb/> (paragraph is brief summary of history of tuberculosis from this source)

${ }^{6}$ Anderson, Diana. Humanizing the hospital: Design Lessons from a Finnish sanatorium. CMAJ (Canadian Medical Association), 2010. 10 August 2009. Web. 8 March 2012. < http://www.cmaj.ca/content/182/11/E535.full.pdf>. E525-E536 
separated and detached from the complex in order to minimize any disturbance to the patients. ${ }^{70}$ Anderson states that the patient's quarters had a roof terrace and rooms with views of the forest and exposure to sunlight. There is a sun balcony on each end of the patient floors and the garden had a winding path and water features to encourage walking. ${ }^{71}$

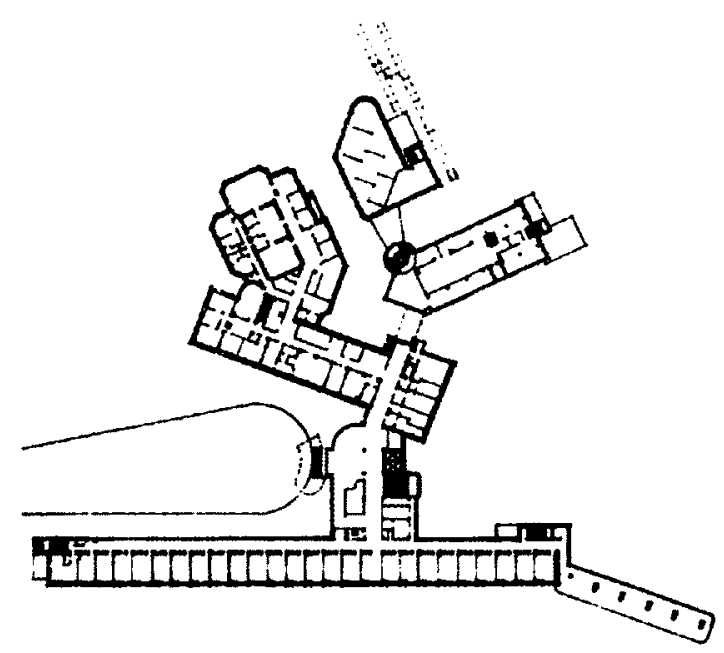

Figure 1 - Welin, Gustaf. Ground plan of the main building. Drawing. Alvar Aalto Through the Eyes of Shigeru Ban. By Shigeru Ban. Eds. Pallasmaa, Juhani, Tomoko Sato. London: Black Dog Publishing, 2007. 113.

The design priority for the sanatorium was the comfort and convenience of the patients. ${ }^{72}$ Fleig states that design emphasized the patient's room and the care of the patient. Each room was limited to two patient beds in to ensure a quiet quite space. The patient rooms

\footnotetext{
${ }^{70}$ Fleig, Karl. ed. Alvar Aalto. Berlin: Birkhăuser, 1963. Fifth uncorrected reprint 1995. Print. 30-43. ${ }^{71}$ Anderson, Diana. Humanizing the hospital: Design Lessons from a Finnish sanatorium. 2010. E525536

${ }_{72}$ Ban, Shigeru. Alvar Aalto Through the Eyes of Shigeru Ban. Eds. Juhani Pallasmaa and Tomoko Sato. London: Black Dog Publishing, 2007. Print. 78.
} 
faced away from traffic and towards the gardens and the forest and are naturally ventilated. $^{73}$

The buildings details and fixtures were designed to be comfortable for the patient. Fleig states that the lavatory basins in the patient's rooms have the water hit the porcelain at an angle to reduce water noise and splashing. The room was heated from radiant elements on the ceiling that was positioned near the patient feet instead of their head. ${ }^{74}$ Other advances for that time were double glazed windows and mobile side tables. ${ }^{75}$

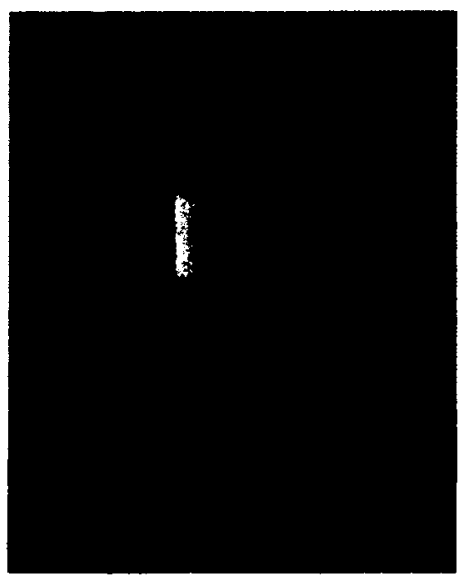

Figure 2 - Kapanen, Martti. Patients'washbasins, and conical light-fitting. Photography. Alvar Aalto Through the Eyes of Shigeru Ban. By Shigeru Ban. Eds. Pallasmaa, Juhani, Tomoko Sato. London: Black Dog Publishing, 2007. 116.

Alvar Alto wrote about the importance of designing for human activities in his article, "The Humanizing of Architecture". He states that human activity must be central to the design process along with the economic and functional requirements of the building. $\mathrm{He}$ viewed architecture and our response to it through the perspective of physiology and psychology. The Paimio Sanatorium can be seen as an experiment with two ideas: “(1)

${ }^{73}$ Fleig, Karl. ed. Alvar Aalto. 1963. 30-43.

${ }^{74}$ Ibid. 30-43.

${ }^{75}$ Ban, Shigeru. Alvar Aalto Through the Eyes of Shigeru Ban. 2007. 78. 
the relation between the single human being and his living room; (2) the protection of the single human being against large groups of people and the pressure from collectivity."76 The first idea is the patient's room where lighting, heat and acoustics are designed for the horizontal person on the bed. ${ }^{77}$ The second idea, although not discussed explicitly in the essay, can be interpreted as the separation and orientation of the patient ward from the other functions of the complex.

Did the Paimio Tuberculosis Sanatorium succeed in its design intent of helping the patient heal? According to reports done by scientists and architects it did. ${ }^{\mathbf{7 8 , 7 9 , 8 0}}$ The building demonstrates that the design focus provided the patient with a comfortable environment that reduced stress. By reducing stress, it gave the patients' bodies a better chance to heal.

For Juhani Pallasmaa, Aalto's architecture does not privilege the eye, but engages the all of the senses including vision. The details and texture of the surfaces are meant to be touched. His buildings are meant to be experienced. ${ }^{81}$ This multi-sensory engagement is evident in the Paimio Sanatorium. For example, acoustics were important part of the design. Insulation was placed in the sanatorium to absorb sound and the faucets were designed so that water hitting the porcelain surface of the sink would not splash or make

\footnotetext{
${ }^{76}$ Aalto, Alvar. "The Humanizing of Architecture." Alvar Aalto in His Own Words. Eds. Goran Schildt. New York: Rizzoli, 1998. Print. 103.

77 Ibid. 102-107.

${ }^{78}$ Sternberg, Esther M. Healing Spaces: The Science of Place and Well-Being. 2009. 5.

${ }^{79}$ Ban, Shigeru. Alvar Aalto Through the Eyes of Shigeru Ban. 2007. 109.

${ }^{80}$ Anderson, Diana. Humanizing the hospital: Design Lessons from a Finnish sanatorium. 2010. E535537.

${ }^{81}$ Pallasmaa, Juhani. The Eyes of the Skin: Architecture and the Senses. 2005. 70.
} 
a noise. ${ }^{82}$ Further, the patient's wing was separated from the rest of the complex to minimize sound from the day-to-day operation of the facility. ${ }^{83}$

The design of the Paimio sanatorium explicitly engaged vision through views of natures, manipulation of the interior lighting and the color of the walls. Each patient's room had views into the surrounding forest that helped relax the patient. ${ }^{84}$ Each room had morning sunlight. The wall lamps were placed behind the patient to minimize glare. ${ }^{85}$ The patient's room were painted in soft colors to create a calming effect while the brighter colors were used in the floors of the corridors to enhance the brightness of the sunlight. ${ }^{86}$

The sanatorium at Paimio was converted to a hospital in 1971 and remains a hospital to this day ${ }^{87}$ and remains as a good example how architecture can assist in the healing.

${ }^{82}$ Anderson, Diana. Humanizing the hospital: Design Lessons from a Finnish sanatorium. 2010. E536.

${ }^{83}$ Fleig, Karl. ed. Alvar Aalto. 1963. 30-43.

${ }^{84}$ Sternberg, Esther M. Healing Spaces: The Science of Place and Well-Being. 2009. 5.

${ }^{85}$ Anderson, Diana. Humanizing the hospital: Design Lessons from a Finnish sanatorium. 2010. E536.

${ }^{86}$ Ibid. E536.

${ }^{87}$ Anderson, Diana. Humanizing the hospital: Design Lessons from a Finnish sanatorium. 2010. E537. 


\section{Maggie's Centres}

Maggie's Cancer Care Centres provides free support for all cancer patients who enter the centre offering counselling, advice and information on the disease, treatments and therapy. The centre allows patients to share their experiences and to learn from each other. All of the care centres are located next to a hospital and most of them are in the United Kingdom. The hospital provides medical treatments while the centre provides support and information to deal with the emotional impact of having cancer and the distress can be associated with it. The psychological and emotional help is seen as complementary to the medical care provided by the hospital. ${ }^{88}$

Maggie's Centres were initially created as a response from the experience of a cancer patient Maggie Keswick Jencks. Jenks was frustrated with the lack of information on dealing with cancer, therapies, and treatments. Patients needed to learn how to cope with the stress. She believed can take a more active role in their treatment through nutrition management, stress management, discussion and education. ${ }^{89}$ Maggie was critical of the the waiting areas in hospitals for not being patient friendly in that they lack views to the outdoors and nature and that they typically had poor lighting conditions, awkward seating arrangements, and no place for privacy. ${ }^{90}$ For example, after Jencks was told that she had

\footnotetext{
The Maggie Keswick Jencks Cancer Caring Centres Trust. Maggie's Cancer Caring Centres. Web. December 27, 2011. <http://www.maggiescentres.org>

Jencks, Maggie Keswick. A View From the Front Line. No Publisher, London: 1995. (Reprinted 2003 and 2007) Web.

$<\mathrm{http} / /$ www.maggiescentres.org/maggies/dms/maggiescentres/publications/general/VFTFL>. 14-16.

${ }^{90}$ Ibid. 21.
} 
cancer, she was forced to sit in the corridor because the hospital so overcrowded. ${ }^{91}$ Jencks responded by writing about the experience, her various therapies and complementary therapies and her desire to create a place for cancer patients to go to for support. She worked with her husband, architect and critic, Charles Jencks, and others to setup the foundation to build Maggie's Centres. Maggie Keswick Jencks died in July 1995. The first Maggie's Centre opened in the following year in November.

The design of the centre is informal and is meant to be like a home; small scale and personable. It lacks the formal institutional aspects and feel of the hospitals, such as a reception desk and paperwork. It is centered around a kitchen where people are free to be as they are, listen or join in on the conversation over food and drink. There are places for group meetings and activities such therapy, lectures, exercises and meditation. There private places for discussion. There are gardens either surrounding the building or within it. ${ }^{92}$

\footnotetext{
${ }^{91}$ Ibid. 20.

92 Jencks, Charles and Edwin Heathcote. The Architecture of Hope: Maggie's Cancer Caring Centres. London: Frances Lincoln, 2010. 13-14.
} 


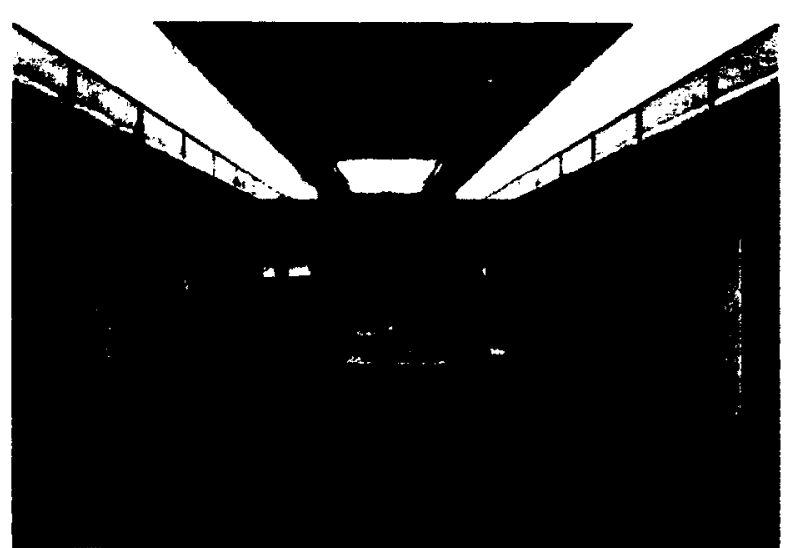

Figure 3 - Kitchen area of Maggie's Cheltenham by MJP Architects. Photography. 4 January 2011. Dezeen. 30 December 2011, <http://static.dezeen.com/uploads/2011/01/dzn_Maggies-Centre-Cheltenhamby-MJP-Architects-3.jpg>

Each Maggie's Centre is designed by a different architect and is unique to its site and context. The architectural brief list the purpose, requirements, practicalities and overall goals of what the building should achieve. It is a set of goals instead of specifics on what the form or organization should be. As a result, the architectural responses are diverse. However there are some commonalities between the centres; most of them have natural light, gardens, views out into the gardens or nature, a kitchen as the center and a domestic instead of an institutional atmosphere.

The programme of the centre is to offer free emotional and psychological support, relaxation and stress management, information, benefits advice and other support for living with Cancer. ${ }^{93}$ The cancer patient is supported by the professional staff, programs/classes, other patients and the environment. The centre's environment is

\footnotetext{
${ }^{93}$ The Maggie Keswick Jencks Cancer Caring Centres Trust. Maggie's Cancer Caring Centres. Web. December 27, 2011. <http://www.maggiescentres.org>
} 
"designed to nurture a community and help people to feel well, it is what the Wellness Community refer to as 'a healing space'."'44

Charles Jencks, co-founder of the Maggie's Centre Foundation, stated that "[w]ith the Maggie's Centres it is the overall involvement of patients and carers that matters the most - the culture more than the building ..."95 He supports this by focusing on the five activities done in the Maggie Centres that make a difference to the patients. First, the "centres can alleviate the death sentence, and thereby negate the negative effect of receiving one." 96 Second, the centres can "alleviate negative stress by teaching patients how to navigate through the problems that come with cancer"97 Third, a change in their behaviour can increase their longevity. A change in diet, exercise and meditation can contribute positively to their health. Fourth, is knowledge of the affects and impact of therapies. ${ }^{98}$

Jencks states that in the Maggie's Cancer Caring Centre "[a]chitecture only plays a supporting role in the plot. It amplifies the message of the [care givers], the way activities are performed, the feelings of the main actors, that is the staff and the patients (not the architects). ${ }^{.99}$ The architecture supports the people and the activities within.

\footnotetext{
"24 Lee, Laura. "Building a Life beyond Cancer: How Maggie's Centre Work". The Architecture of Hope: Maggie's Cancer Caring Centres. Charles Jencks and Edwin Heathcote. London: Frances Lincoln, 2010. Print. 49.

${ }^{95}$ Jencks, Charles and Edwin Heathcote. The Architecture of Hope: Maggie's Cancer Caring Centres. London: Frances Lincoln, 2010. 40.

${ }_{96}$ Ibid. 40.

${ }^{97}$ Ibid. 40.

${ }^{98}$ Ibid. $40-41$.

${ }^{99}$ Ibid. 41.
} 


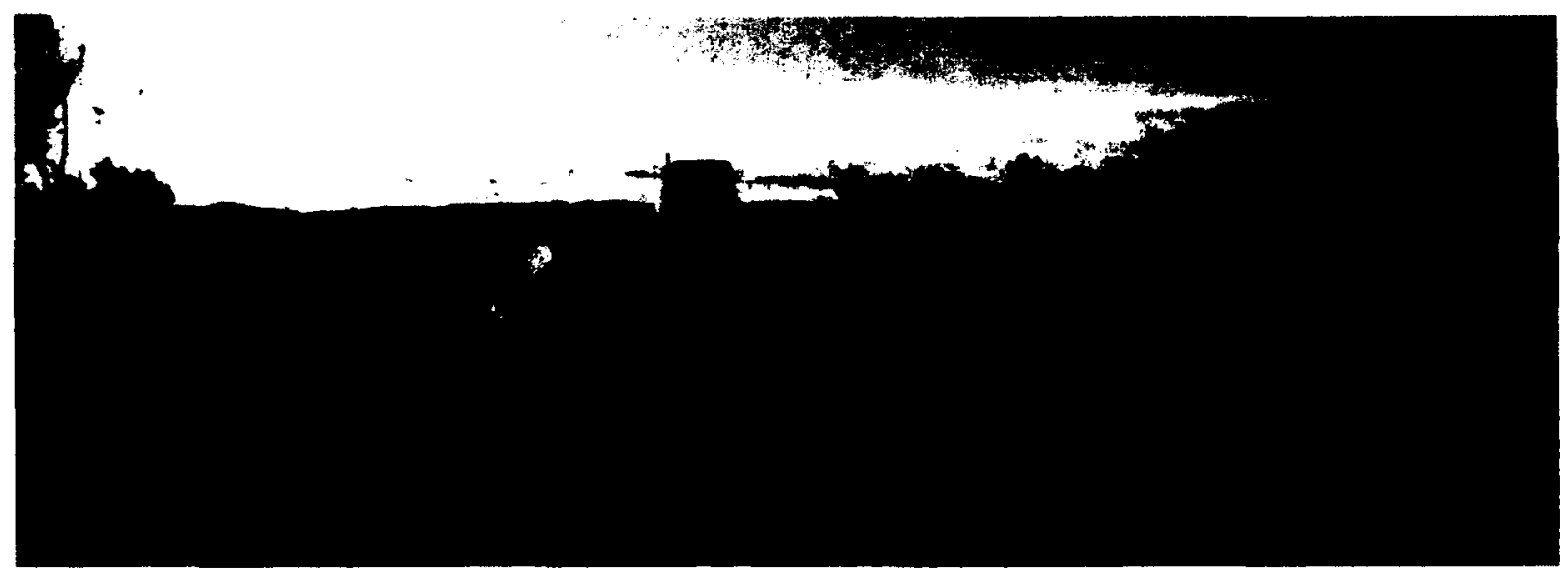

Figure 4 - Dundee Maggie's Centre. Photography. Maggie's Centre. 29 May 2012, < http://www.maggiescentres.org/maggies/maggiescentres/home/centres/dundee/building/imageParagraphs/0 /image/dundeetopwide.jpg>

One of the most architecturally interesting centres is Maggie's Dundee Centre in the U.K. designed by Frank Gehry in 2003. It has white exterior walls, a tower and a folded grey metal roof. The underside of the metal roof is a warm, exposed timber structure. Visitors enter through to the lobby and then proceed to the library, common room or kitchen. The interior is "organized around a social space, the kitchen table". 100 The prominent material used throughout the interior is wood, including flooring, windows, doors and furniture.

Maggie's Dundee has a labyrinth garden with a single path in and out. The patients can walk the garden "as a form of contemplation"101. It can be calming because when people are walking the labyrinth they tend to focus on their breathing and the rhythm of their

${ }^{100}$ Ibid. 120.

${ }^{101}$ Ibid. 29. 
steps. The walk engages the senses of vision, hearing, smell and touch with views from the interior of the centre of the surrounding forest, mountain and rivers. ${ }^{102}$

Does the Maggie's Dundee contribute to the healing process? Between 2005 and 2007, a post occupancy evaluation was done by the University of Dundee. ${ }^{103}$ The study evaluated the "visitor and staff responses as users of the building, physical performance of the building [and] the design and construction process" ${ }^{\prime 104}$. The evaluation process involved interviews with the staff, volunteers and architects, as well as questionnaires for the visitors. Some of the key objectives of the study were to determine the effectiveness of the design in relation to its original intent, user satisfaction, and people's perception of the centre in relation to their comfort, wellbeing and health. The report found that the strength of Maggie's Dundee were that the design concept was closely aligned to the Maggie's Centre model; it had good views to the exterior, a good amount and quality of natural light, a hospitable kitchen area, space flexibility and good staff. The weaknesses of the design were insufficient ventilation, too much solar gain and uncomfortable chairs.

Overall the centre received "positive comments from visitors in relation to health and wellbeing"105 The study states that "there is a positive correlation between many design aspects of the building and visitors sense of health and wellbeing at the time [while in the building]. What is not clear is whether visitors' sense of wellbeing and health is

\footnotetext{
102 Jencks, Charles and Edwin Heathcote. The Architecture of Hope: Maggie's Cancer Caring Centres. 2010. Print. 29.

${ }^{103}$ Stevenson, Fionn \& Mike kHumphris. A Post Occupancy Evaluation of the Dundee Maggie Centre. Ecological Design Group, School of Architecture, University of Dundee: March 2007.

${ }^{104}$ Ibid.

${ }^{105}$ Ibid.
} 
influencing their perception of the building's qualities, or whether the building's qualities are affecting visitors' perception of their health and wellbeing." 106 The report did not set out to prove a direct correlation between the building qualities and the perception of health and wellbeing, therefore, this direct correlation is inconclusive. However, as the report indicates, it is an area for further investigation. ${ }^{107}$

${ }^{106}$ Ibid.

${ }^{107}$ Ibid. 


\section{Stephen Avenue}

A street designed for social activities can help revitalize a neighborhood. The city government, along with its policies and local businesses need to work together towards making the experience of the place a priority. The architecture and the design of the street can improve the place. Stephen Avenue in Calgary, Alberta will be the case study. It is also known as 8th avenue. It was a successful conversion of a main street into a pedestrian oriented street that helped revitalize the street and the surrounding area. The following sections will explain the history and the reasons for Stephen Avenue's growth, decline and renewal. The final section will discuss how designing to fit the human senses and activities can improve the street.

Stephen Avenue is a pedestrian street in downtown Calgary with many historical buildings from the 1900s that are intermixed with tall contemporary buildings. Many of the historic buildings on the street are two to three stories in height and were constructed with Sandstone in various styles such as Classical Revival, Beaux-Arts Classicism, Romanesque Revival and Gothic Revival. The street is aesthetically pleasing with wide inlaid brick sidewalks, decorative lamp posts, benches and closely spaced deciduous trees. The avenue is known for its restaurants, architecture and history. The restaurants open their patios along the sidewalk during the spring and summer months. The street has one lane for one way traffic and another lane for parking. Sections of the street can 
be closed to vehicular traffic for special events. This area has a high density of historical buildings and a portion of it was designated as a National Historic District in 2002. ${ }^{108}$

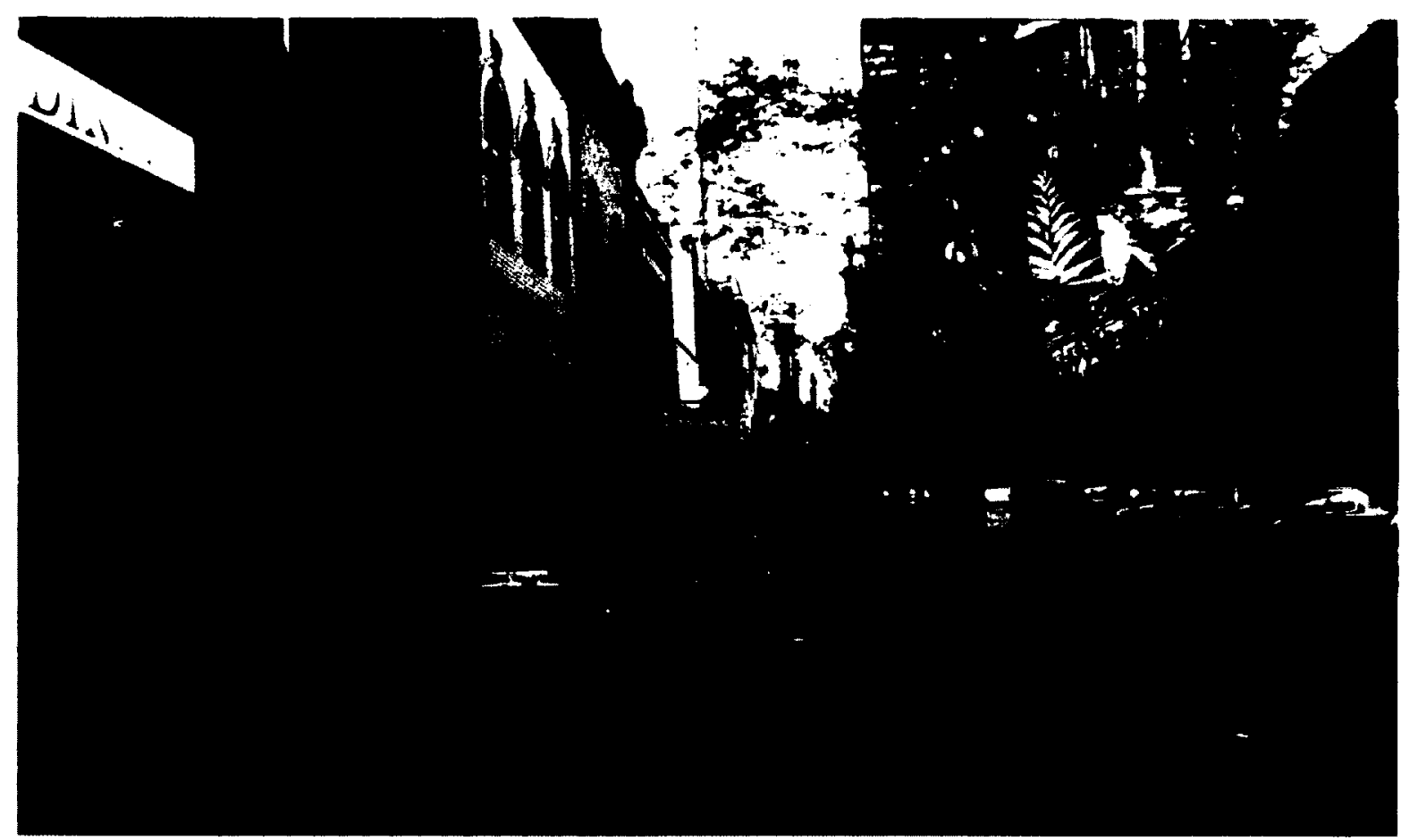

Figure 5 - Photograph of Stephen Avenue in Calgary, Alberta (Source: Greg Fung)

The economic growth and decline of Alberta's industries had a major role in the development of Stephen Avenue. In the 1900s, Stephen Avenue was Calgary's main commercial street. ${ }^{109}$ It had banks, stores and restaurants. It was a gathering place for Calgary's residents. In the 1880's, the Canadian Pacific Railway (CPR) extended its railway through Calgary and it consequently established the city as a main transportation hub. ${ }^{110}$ The railway is one block south of 8 th Avenue (Stephen Avenue). The growing agricultural and cattle industries also brought people and wealth into the area, which led

\footnotetext{
${ }^{108}$ Calgary Heritage Authority. Historic Downtown Calgary: Including Calgary's National Historic District 'Stephen Avenue'. Calgary: Calgary Heritage Authority, 2005. Print. 2. ${ }^{109}$ Ibid. 2.

${ }^{110}$ Dorothy, Field. ed. Calgary: Stephen Avenue and Area Historical Walking Tour. Edmonton: Alberta Community Development, 1995. 3.
} 
to more buildings being constructed on Stephen Avenue. A majority of the buildings on the street were constructed from timber frames and many were burnt down in the fire of 1886. Many buildings afterwards were constructed with Sandstone from a local quarry. Property values along 8th avenue increased $1000 \%$ in between 1882 and 1912 and in order to maximize profits, developers began to construct taller buildings using reinforced concrete and steel. ${ }^{11}$ After World War I, there was a recession in the economy and a depletion of local construction-quality sandstone lead to the halt of using it as construction material. ${ }^{112}$ The local economy did not recover from the recession until after World War II and with the discovery of oil at Leduc, Alberta in the 1940's. ${ }^{113}$

Much of Calgary's growth and development after World War II was due to the rise of oil and gas industries in Alberta. The growth of those industries increased the demand for more office space. The discovery of oil in Leduc, near Edmonton, in 1947, should have resulted in Edmonton as the logical choice for the hub of the Alberta oil industry. ${ }^{114}$ However, both Edmonton and Calgary at the time lacked office space. ${ }^{115}$ A Calgary developer saw this opportunity and quickly constructed an office building based on speculation. ${ }^{116}$ "As soon as it was built, Mobil, Shell and Sun Oil moved in, establishing Calgary as the provincial capital of the oil industry."117 Many oil and gas companies had their headquarters in Calgary, which lead to further development of financial and

\footnotetext{
${ }^{111}$ Ibid. 56.

${ }^{112}$ Ibid. 4.

${ }^{113}$ Ibid. 4.

114 lbid. 44.

${ }^{115}$ Ibid. 44.

${ }^{116}$ Ibid. 44.

${ }^{117}$ Ibid. 44.
} 
ancillary services supporting it. ${ }^{118}$ This increase in companies in the city lead to construction of office towers in downtown to meet the need for office space.

During the 1960's, many shopping centres opened in Calgary's suburbs to cater to the residents living in those area. During that time the city was also actively promoting the development of suburban shopping centres. The opening of retail strip centres, big box stores and power centres led to the decline of people visiting downtown. Many businesses moved out of downtown and into the suburbs. However, the oil and gas industry remained in the downtown core because it is "very transaction based and values clustering downtown"119. The services related to this industry also remained. ${ }^{120}$ (Neill, 2011: 195-196)

Even with the oil and gas industry remaining in downtown, there was still was a decrease in the number of people visiting downtown after work hours. There was also a decline in the quality of downtown life after work hours and the streets became less pedestrian oriented. Many of the historical pedestrian scaled buildings were demolished to make way for new office towers. ${ }^{121}$ The heights of the office towers were too tall and did not relate the human scale. Streets were widening to make room for automobile traffic. ${ }^{122}$ The space for pedestrian on the street was reduced. A network of enclosed elevated walkways, called Plus 15, were constructed to connect the office towers. The walkways

\footnotetext{
${ }^{118}$ Neill, David Leigh. "Historic Districts and Their Role as Sustainable Regenerators of Downtown City Life". Thesis. University of Calgary, 2011. Web. 31 May 2012. <http://dspace.ucalgary.ca/bitstream/1880/48432/1/2011_Neill_PhD.pdf>. 184.

119 Ibid. 196

${ }^{120}$ Ibid. 195-196.

${ }^{121}$ Ibid. 97.

122 Ibid. 97
} 
benefited the office workers in the winter because it is a controlled warm environment connecting the office towers. The walkways separated the pedestrian traffic into two different levels. It separated and dispersed the pedestrian traffic on the street. Calgary's public transit system used rail transit (LRT) to move people quickly and efficiently to and from downtown. Some of the downtown LRT stations connect directly to the Plus 15 walkway systems and had inadvertently kept people off the streets. ${ }^{123}$ Parking is expensive during the weekday and it lessens the appeal of a trip to downtown. ${ }^{124}$ Those reasons made downtown an unappealing place to visit and to walk around on the streets. The liveliness of a street depends partially on the amount of people and events on it and the duration that people stay on it. ${ }^{125}$

The decline of Stephen Avenue and downtown Calgary as a destination after work had begun and continue to decline. Several projects were created by the city and developers to counteract the draw of people away from downtown and into the suburbs. Several interior malls and shopping complexes were constructed in Calgary's downtown to attract people to the area. ${ }^{126}$ However, the combination of the downtown shopping complexes and the Plus 15 walkway system had weakened the retail viability of Stephen Avenue. ${ }^{127}$ Between the 1960's and the 1970's, retailers moved from Stephen Avenue into the suburban and interior malls leading to a further decline of the street. ${ }^{128}$ Stephen Avenue

\footnotetext{
${ }^{123}$ Ibid. 200.

124 Ibid. 200.

${ }^{125}$ Gehl, Jan. Life Between Buildings: Using Public Space. 2006. Print. 77-79.

${ }^{126}$ Neill, David Leigh. "Historic Districts and Their Role as Sustainable Regenerators of Downtown City Life". 2011. 201-202.

${ }^{127}$ Ibid. 201-202.

${ }^{128}$ Ibid. 205.
} 
became a poorly maintained street with vacant stores and a place for the homeless, beggars and social delinquents. ${ }^{129}$

David Neill states that other private and public projects were constructed in the late 1960 's to 2000 nearby 8 th Avenue to help it recover. Such projects were the Calgary Tower, Calgary Convention Centre, Glenbow Museum, Performing Arts Centre, Calgary Municipal Building and Olympic Plaza. However, it was not enough to revitalize the street. It had resulted in the demolition of historic buildings along 8th Avenue. However, it did replace the sections of the area that had deteriorated. ${ }^{130}$

In 1970's, a section of 8th avenue was converted to a pedestrian mall called Stephen Avenue Mall. ${ }^{131}$ Neill states that there was some initial success but several years afterwards it became unsuccessful because people were not interested in shopping in the stores. In the late 1980 's, the city of Calgary a did a study to revitalize Stephen Avenue and designated a section of it as a permanent pedestrian mall. It renovated the street with new sidewalks, roadway, street furniture and historical lamps. However the quality of the stores remained poor. ${ }^{132}$

Neill further reports that Management of the street was assigned to the Calgary Downtown Association (CDA) in 1996. This association is responsible for managing the revitalization of downtown. Traffic was eventually allowed in the evening along

\footnotetext{
${ }^{129}$ Ibid. 205

130 lbid. 206-209

131 lbid. 209-210.

${ }^{132}$ Ibid. 209-210.
} 
Stephen Avenue in the evening with free parking on the street. The CDA promoted and marketed the street to the public. ${ }^{133}$ Major building renovations and restorations occurred from 1996 to 1998 on Stephen Avenue. Neill reports that most of the renovations restored the buildings back to their original historical facades. In 1997, several buildings were renovated and redeveloped into retail stores and restaurants. The successes of those businesses lead to more restaurants being opened along Stephen Avenue. Eventually the area became known for its restaurants. ${ }^{134}$

There are several policy changes that facilitated the recovery of Stephen Avenue. Neill explains that the city increased policing of downtown. The presence of the police officers reduced the amount of crime, beggars and homeless in the street. A zoning requirement was set so that the ground floor of the buildings along a section of 8th avenue were to be for public uses such as restaurants and stores instead of offices. The city implemented a bylaw that restricted the height of buildings being constructed on the southern side of the historic portion of Stephen Avenue, in order to prevent shadows from being cast onto the street. Funding and grants were provided to restore the facades of several historical buildings. ${ }^{135}$

Presently, Stephen Avenue an active street with many high quality restaurants and stores, located in well maintained historical and contemporary buildings. It is a street with sufficiently wide sidewalks, benches, trees and historical street lamps, along with sections

133 Ibid. 211.

${ }^{134}$ Ibid. 214-232.

${ }^{135}$ Ibid. 213-232. 
of low rise buildings that allow sunlight onto the street; making the street a pleasant place to walk. The avenue is a destination for people to go to and to meet up with their friends for a meal, to watch street buskers, attend special events or activities. Its history was discussed in the previous section and the next section will further explore why it is a successful street. I will be using my observations of Stephen Avenue and observations made by Jan Gehl on the qualities of effective public spaces to illustrate how Stephen Avenue is a successful public space.

Jan Gehl, in his book, Life Between Buildings, states that outdoor activities in public spaces can be generally categorized into three types of activities: necessary, optional and social activities. Necessary activities are compulsory everyday tasks such as going to work or buying groceries. They are activities that we are required to participate in. Since those activities are necessary, the quality of the environment has minimal effects on it. The second type of activities is optional activities that we do when we have time, such as taking a walk and sitting in a park. Those activities depends on if the conditions and quality of the environment are complimentary to it. The third type is social activities and they depend on other people being in the space and on the quality of the environment. Some examples of social activities are conversations, communal activities and children playing. Just seeing and hearing other people on street are also considered to be a social activity. Social activities are a result of optional activities and are dependent on the quality of space. ${ }^{136}$ (Gehl, 2006: 9-13)

${ }^{136}$ Gehl, Jan. Life Between Buildings: Using Public Space. 2006. Print. 9-13. 
People are attracted by human activities and other people. People need stimulation. Observing and interacting with other people can be simulating. People and activities can be more interesting and varied than the built environment. Yet activities are dependent on the quality of the space around it. The physical environment does not directly affect activities but architects and planners can affect the possibilities for activities to occur through design of the space. (Gehl, 2006: 13-25).

The activities on Stephen Avenue and its restaurants are some of the reasons why the street is lively and successful. Optional activities, such as walking down the avenue become an opportunity to see and hear others. Necessary activities, such as eating, become a reason for other social activities such as meeting friends. The CDA promotes activity on the street by organizing special events on Stephen Avenue and allowing buskers and street food vendors on the street. Stephen Avenue has become a destination. Gehl states that activities tend to be self-reinforcing. As people observe activity they will tend to join in. As more people participate or observe an activity, the more the people will become attracted to it. The activity becomes larger and lasts longer. The longer the duration of the activity, the better the opportunity for it has to grow. ${ }^{137}$ This is seen on Stephen Avenue in the form of buskers and restaurants. The buskers on the street attract people and as more people watch, even more people gather around. An active and busy restaurant will draw more interest from people walking by it. A street full of people will feel more lively and interesting and will attract even more people to it.

${ }^{137}$ Ibid. 23-76. 
A successful restaurant on the street can lead to more restaurants opening which add more destinations for people to visit.

A good public space needs to have a scale and a dimension that relates to the pedestrian. Our senses have a limited range of perception. The closer the distance, the more detail we perceive. Our sense of sight has the furthest range, followed by hearing, smell and touch. We have a range of distances in which we feel comfortable for different kinds of social interaction, they are: intimate distance $(0-0.45 \mathrm{~m})$, personal distance $(0.45 \mathrm{~m}-1.30 \mathrm{~m})$ social distance ( 1.30 to $3.75 \mathrm{~m}$ ) and public distance $(>3.75 \mathrm{~m}) .{ }^{138}$ The dimension of public space needs to be within the range of our senses. Activities or social interactions need to be in a space that is appropriate for it. Good public spaces in cities tend to be the ones that we experience at close proximity and have modest building dimension. ${ }^{139}$ Impersonal spaces are large, wide, empty and have tall buildings. ${ }^{140}$ This can be seen in how most people find that the streets and squares of old European towns more appealing to walk and stay in than some of the modern streets that were designed for the automobile. Stephen Avenue has a mixture of both the intimately scaled buildings and large office towers along it. People can relate their body to the proportions of the two to three story buildings on Stephen Avenue. They can perceive the whole building. On the contrary, the office towers are too tall to perceive within one glance and is not within our field of vision. It is difficult to relate to the scale of the building.

\footnotetext{
138 Ibid. 69.

139 Ibid. 69.

140 Ibid. 69.
} 
The pedestrian traffic in downtown Calgary is separated on two levels, one on the street and the other on the Plus 15 elevated walkway. Parallel paths disperse people and events. ${ }^{141}$ It reduces the opportunity for seeing and meeting people and engaging in activities. In order for a public space to be successful, the activities need to be on one level and be within our range of sensory perception.

The way a space is designed and the quality of the space affects the type of activities that can happen within it. The better the environment, the more likely people will stay in it and participate in social activities. The design of the built environment can influence what type of activities may occur. The basic activities of walking, standing, sitting, seeing, hearing and talking are the basis for most other activities such as in social and recreational activities. ${ }^{142}$ Stephen Avenue can be examined to determine how it addresses those basic activities and how they contribute to making the street an attractive and a pleasant place.

Stephen Avenue has good spaces for walking, standing and sitting. It has wide sidewalks on either side of the street to allow for two to three rows of pedestrians to walk freely even when patios are open along the sidewalk. Yet it is not too wide to feel barren with the dispersion of people. The distance between the buildings and storefront along the street are close together providing many points of interests within a short walk. There are places to stop, stand and to talk on the street.

141 Ibid. 100.

142 Ibid. 131. 
Gehl proposes that the edge zones are popular places to stay. He explains that they are the best locations for observation viewpoints. People being in the boundary (edge zones) between the two zones can see others while still having access to two different zones. When people are at the edge of the facade they their back protected. The edge zones also give people an option to move between two areas. ${ }^{143}$ Stephen Avenue has two edge zones in which people can stay in. One is at the edge of the facade and the street and the other is at the boundary between the sidewalk and street that has lamp posts, benches and trees. Stephen Avenue has benches and trees at the edge zones to provide shaded places to sit. The patios are a place to eat, socialize and observe.

Stephen Avenue has a mix of good and bad areas for seeing, hearing and talking. The street is well illuminated and most sections have direct sunlight. However, there are sections of the street where the tall office towers would block out most of the sunlight. The storefronts have large windows where people can see in and out to the other people and activities. The street is relatively quiet when compared to the rest of the downtown area due to the reduced vehicular traffic keeping the background noise level low. The low noise levels allow people to have conversations and the variety of architecture, activities and destinations gives them something to talk about.

Stephen Avenue is a good example of how a street that is redesigned for human activities can help revitalize the neighborhood. It is a combination of architecture, urban design, attractions, events, businesses, programming and proper management of the street that

${ }^{143}$ Ibid. 149-151. 
creates a thriving pedestrian street. The architecture and street design helps to facilitate interaction between people and generates an interesting environment. There are destinations, such as restaurants and stores that make the place unique and different. It is well managed and outdoor events are planned for the street during warmer parts of the year. It is an environment that is comfortable and safe for pedestrians. 


\section{Site}

The site chosen for the thesis project is a one block area on Somerset Street, between Preston and Rochester, at the west end of Ottawa's Chinatown. The project address five urban acupuncture points along the street with the intention of rejuvenating the area now at a point of transition. In order to develop a overall prognosis for the site, it is necessary to understand the larger context in which the Chinatown site is situated. Like the human body, all parts of the city are interconnected - from the macro to the micro.

\section{Ottawa}

Ottawa is the capital city of Canada with a population of 1.258 million in the metropolitan area. ${ }^{144}$ The metropolitan area includes Gatineau, Québec and the former Ontario municipalities of Cumberland, Gloucester, Goulbourn, Kanata, Nepean, Osgoode, Ottawa, Rideau, Rockcliffe Park, Vanier, and West Carleton - amalgamated together as the city of Ottawa in 2001. ${ }^{145}$ As the capital of Canada, Ottawa is home to the Parliamentary Precinct, headquarters of federal government agencies and various national institutions. It has two major universities, Carleton University and University of Ottawa.

\footnotetext{
144 Population of census metropolitan areas. Statistics Canada, 07 March 2012. Web. 26 March 2012. $<$ http://www40.statcan.gc.ca/101/cst01/demo05a-eng.htm>

${ }^{145}$ Profiling Progress - An Introduction to Ottawa. City of Ottawa. Web. 26 March 2012. $<$ http://ottawa.ca/en/city_hall/planningprojectsreports/annual_report/2004/profiling_progress/; Permalink : http://ottawa.ca/e/W3002885 >
} 
The Ottawa River runs west-east along the northern edge of the city, marking the border between Ontario and Quebec. The Rideau River runs north-south through and separates the city centre from the east end neighbourhoods. The Rideau Canal, a world heritage site, diverts water from the Rideau River and intersects the Ottawa River beside the Parliament Buildings. Major Green spaces in or around the city includes Gatineau Park, Rideau Canal and the Green Belt.

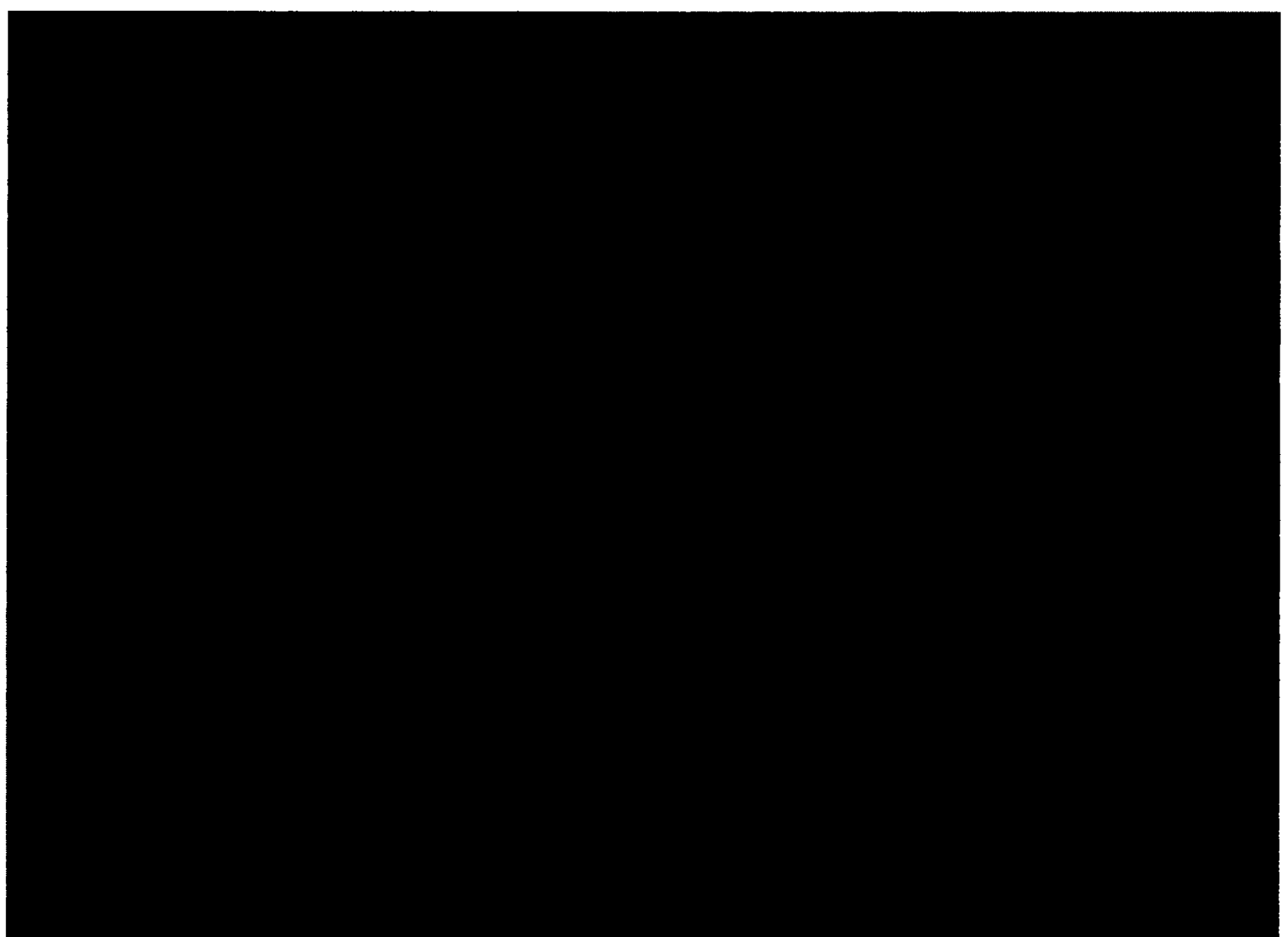

Figure 6 - Aerial Photograph of Ottawa and Hall (Aerial Photograph Source: Google \& Terrametrics, 2012. Web. 24 May 2012. <http://maps.google.ca>; Overlay Source: Greg Fung)

Ottawa's Greenbelt was conceived in 1956 as part of the Gréber plan and was meant to contain urban development. However new communities - created outside of the system 
have since been incorporated into the city. ${ }^{146}$ In Ottawa's $20 / 20$ official plan it is designated for agricultural, cultural, and recreational use. ${ }^{147}$ The Greenbelt 2067 Vision is a new concept plan being develop as part of the ongoing development of Horizon 2068: The 50-Year Plan for Canada's Capital. The concept plan states that the Greenbelt is to be part of the Capital Ecosystem Network with a mix of natural environment and sustainable agriculture. It is meant to contribute to the "sustainability and quality of life". ${ }^{148}$ The Greenbelt and the 'natural' landscapes with and surrounding Ottawa play an important role in the health of the city and its citizens.

146 Ottawa Through Time From the Andrews-Newton Photographs: Green Belt. City of Ottawa. 20012012. Web. 26 March 2012.

$<$ http://ottawa.ca/en/rec_culture/museum_heritage/archives/history/construction/greenbelt/index.html; Permalink: http://ottawa.ca/e/CON060265>

${ }_{147}$ Ottawa 20/20 Official Plan: 3.5 Greenbelt. City of Ottawa. 2001-2012. Web. 26 March 2012. $<$ http://www.ottawa.ca/city_hall/ottawa2020/official_plan/vol_1/03_design_land_use/index_en-05.html> 148 Fact Sheet: Overview of the new Greenbelt Master Plan Recommended Land Use Concept. National Capital Commission. 25 January 2012. Web. 26 March 2012. <http://www.canadascapital.gc.ca/placesto-visit/greenbelt/news/2012-01-25/fact-sheet-overview-of-new-greenbelt-master-plan> 


\section{Brief History of Chinese Immigration into Canada and Ottawa's Chinatown}

Each of the several generations of Chinese living in Canada has a clearly different experience from the previous generations. The first generations, beginning in the midnineteenth century, were primarily uneducated males immigrants. They had come to work as labourers for the railroad, in mines, and in restaurants and laundries. The money they made was sent money back to support their families who stayed in China. Very few of the immigrants spoke English. The Chinese at that time faced strong racism from the rest of the population in Canada and discrimination in the immigration laws in the form of head taxes. ${ }^{149}$

The second wave of Chinese immigration began after the lengthy civil war in China (1927-1950). This was in part due to changes in Canadian immigration laws following the Second World War. The new laws allowed the Canadian Chinese citizens to bring their families to Canada. They were better educated and eventually had professional jobs in the community. This second generation of immigrants revived a diminishing Chinatown in Ottawa. ${ }^{150}$

In 1967, Canada changed its immigration entry laws to accept immigrants based on their merits. Those rules favoured people with a higher education, knowledge of the English language and had required job skills. In the 1980 's, a new rule was introduced to allow

\footnotetext{
${ }^{149}$ Summary, paragraph information source from: Yee, Paul. Chinatown: an illustrated history of the Chinese communities of Victoria, Vancouver, Calgary, Winnipeg, Toronto, Ottawa, Montreal and Halifax. Toronto: J. Lorimer, 2005. 2005. Web. 14 January 2012. $<$ http://site.ebrary.com.proxy.library.carleton.ca/lib/oculcarleton/docDetail.action?doclD=10210337> ${ }^{150}$ Ibid. (summary)
} 
people with capital and investments in Canada to easily immigrate to Canada. Several events in Hong Kong between 1967 and 1997 increased Chinese immigration to Canada. Such events were the suppression of citizen dissent by the government and the stock market crashes. The rise of Hong Kong as a world financial centre and world port, along with an increase in the wealth of its citizens facilitated immigration. In 1997, Hong Kong was handed over from the British back to China. The stock and housing prices rose afterwards and it drew many immigrants from Canada back to Hong Kong. ${ }^{151}$

After 1995, many of the Chinese immigrants came from mainland China. Many came over as skilled workers or as business immigrants. They left China "because of its police state, one-child policy, over-population, and lack of freedom." 152,153

Historically, Chinese immigrants tended to move to cities that had an established Chinatown and jobs. Chinatown provided the immigrants with Chinese language based services and community groups. Today however, Chinatown is now no longer essential to most Chinese immigrants and it has become optional. The majority of the Chinese in Ottawa are no longer living in or around Chinatown. Chinatown has a become more a representation of Chinese Canadian culture and history, and less a neighbourhood. ${ }^{154}$

Early Chinese immigrants worked as labourers in Ottawa. In the first decade of the $20^{\text {th }}$ century, various Chinese owned restaurants and laundries were established around

${ }^{151}$ Ibid. (summary)

152 Ibid. 21.

${ }^{133}$ Ibid. (summary)

${ }^{154}$ Ibid. (summary) 
Ottawa. In 1921, the Chinese (Christian) Mission was established and it helped the community through English language classes and providing support. The Mission later became the Chinese United Church. By the 1920's, a Chinatown was formed along Albert street with laundries, restaurants, groceries and stores. In 1971, the first Somerset Street Chinese restaurant opened up. The population of Ottawa's Chinatown grew with the immigration of Chinese from Hong Kong in the 1970s and multiple businesses open up on Somerset Street. In 1979, the city of Ottawa led a program to sponsor refugees from the Vietnam War, which resulted in large immigration of Vietnamese people into the Ottawa. ${ }^{155}$

In the 1980's, the city wanted to redevelop Somerset Street. Yee reports that in 1986, the "Chinese commercial groups wanted to shape the area into a more distinctive Chinatown to draw more business. Other merchants and area residents wanted Somerset Street to remain multicultural and not to highlight one race. They preferred a variety of shops and restaurants, and argued that new businesses shouldn't push existing ones out. But those who favoured a distinctive Chinatown, including the mayor, feared that a more inclusive approach would make the street 'just another commercial business strip.' After many consultations, plans for a distinctive Chinatown were dropped, and Somerset Street developed on its own." 156,157

\footnotetext{
155 Ibid. (summary)

${ }^{136}$ Ibid. 96.

157 Ibid. (summary)
} 
In 1989, Hong Kong immigrants were one-third of the Chinese community in Ottawa. They had a substantial effect on Ottawa, such as establishing Chinese newspapers, Cantonese based community centres and churches, and dragon boat races. In the 1990s, the majority of Chinese immigrants to Ottawa were from Mainland China. This influx of Mandarin speaking Chinese caused the main languages used in some Chinese churches to be switch from Cantonese to Mandarin. ${ }^{158}$

Today, Ottawa's Chinatown is located along Somerset Street between Champange and Bay Street with business owned and operated by Koreans, Vietnamese, Indians, Iranina, Iraqis and Japanese. ${ }^{159}$ The section of Chinatown that will be the focus of this thesis is along Somerset Street between Preston and Rochester Street. Somerset Street has Asian restaurants, Chinese medicine stores, groceries, residences and other retail stores. The majority of the buildings are residential buildings converted into ground level shops with second story residences.

While Chinatown has been the historical destination for Chinese immigrants, they have tended to leave the neighbourhood as soon as they have the resources. This has left a void in the neighbourhood now being filled by other immigrant groups and gentrification. However there is still significant interest by residents, business owners and the city to retain the character of Ottawa's Chinatown. One of the noteworthy improvements to the area was the construction of Ottawa Chinatown Royal Arch in 2010 on Somerset Street near Bronson Avenue.

158 Ibid. (summary)

159 Ibid. 
Somerset Street is part of the physical and symbolic cultural and historical representation of the Chinese and Asian community in Ottawa, the neighbourhood is changing. In its essence, Chinatown has left this area of Somerset between Preston and Rochester. There are empty lots from demolished buildings that are left unused or converted to ad hoc parking lots. The stores and buildings are sparsely spread out along the street. The quality of the buildings and the street itself are deteriorating. There is no unifying element to it; the buildings look unplanned and have improvised low quality renovations. In order to restore the 'health' of the street and the neighborhood, the street requires a gentle realignment of its programme and infrastructure if it is going to make welcome new immigrants and other new residents to the area. Interventions are needed in the empty lots to stimulate activity and reinvigorate life along the street. 


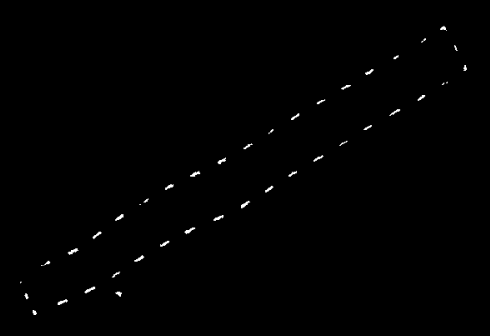

9

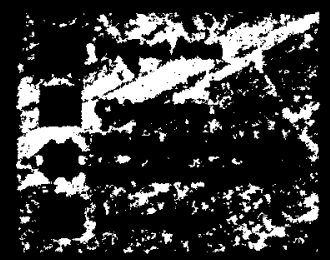

Figure 7 - Aerial Photography of Ottawa Chinatown along Somerset Street, (Ottawa Air Photograph Source: City of Ottawa, retrieved from Carleton University Library; Overlay and Labels Source: Greg Fung) 


\section{The Five Sites}

The project area for this thesis is Somerset Street in Ottawa Chinatown is between Preston Street and Rochester Street. Ottawa's Chinatown has been selected as the area for this project because it is related to the idea of holistic approaches to medicine in the form a traditional Chinese medicine stores and various acupuncture centres. This area of Chinatown is an ideal area for renewal due to its deterioration and vacant lots offering spaces for intervention. The intersection of Chinatown on Somerset street and Little Italy on Preston street can be a parallel to intersection of the western and eastern ideas in this thesis. A potential business reason for the project is that the Plant Bath Recreation centre is across from the main project of a cafe and physiotherapy clinic. The patrons from the recreation centre can use the cafe as place to meet and the clinic for the health needs.

The City of Ottawa is currently in the process of reconstructing Somerset Street from Spadina Avenue to Booth Street. It is schedule to finish by the end of spring 2012. The reconstruction or rehabilitation includes work on road surface and structure, sidewalk, signage, street lighting, transit and bicycle facilities. ${ }^{160}$

Five "unhealthy" sites have been selected on Somerset Street for their location, potential and availability. Each site sites are either empty lot or an existing ad hoc parking lot.

\footnotetext{
${ }^{160}$ Somerset West Reconstruction. City of Ottawa. Web. 26 March 2012. $<$ http://ottawa.ca/en/city_hall/planningprojectsreports/construction/projects/somerset_west/; Permalink: http://ottawa.ca/e/CON051296 >
} 
The open sites are selected over the occupied sites because of their potential to be a new architectural intervention into the existing urban environment. The main site (site 1) has been primarily been selected because its relation the services and activities of its surrounding. The remaining four sites (site 2 to five) are used to fill out the vacant lots on the street and to provide additional services and buildings to the neighbourhood. Instead of an intrusive demolishment and replacement of an existing building, a new intervention is placed on the site to reinvigorate the street and the neighborhood. It builds upon what already exists in the community instead of removing parts of it. 

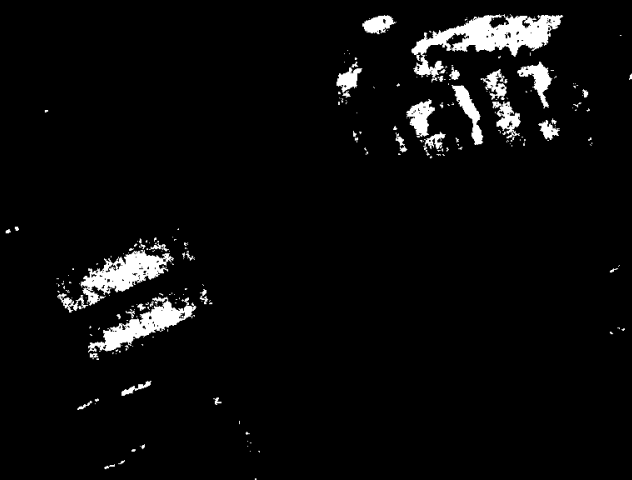

Figure 8 - Aerial Photography of Project Area in Ottawa Chinatown along Somerset Street, (Ottawa Air Photograph Source: City of Ottawa, retrieved from Carleton University Library; Overlay and Labels Source: Greg Fung) 


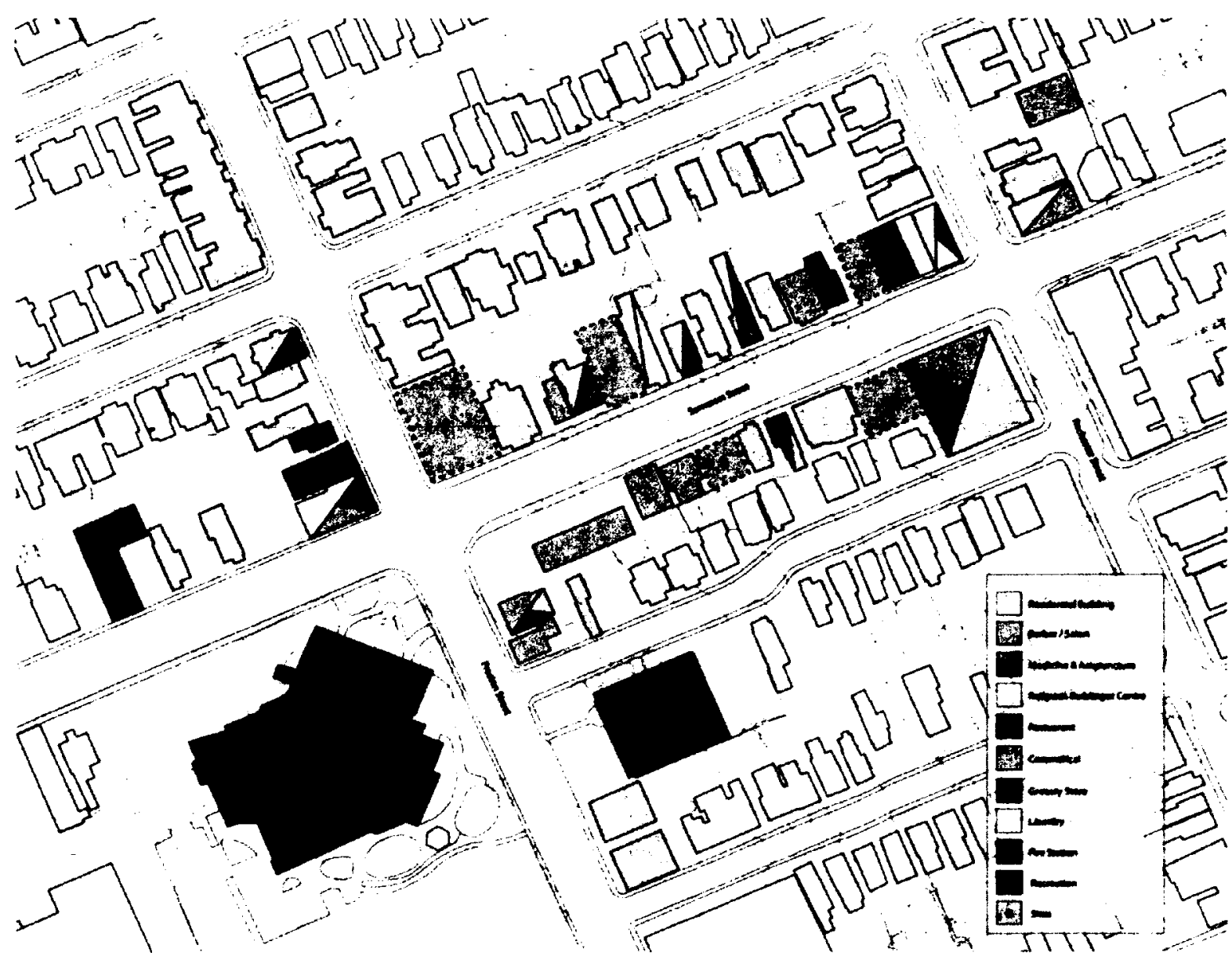

Figure 9 - Site Plan with Building Types (Original Site Plan Source: City of Ottawa retrieve from Carleton University Library; Overlay of Building Types and Labels Source: Greg Fung)

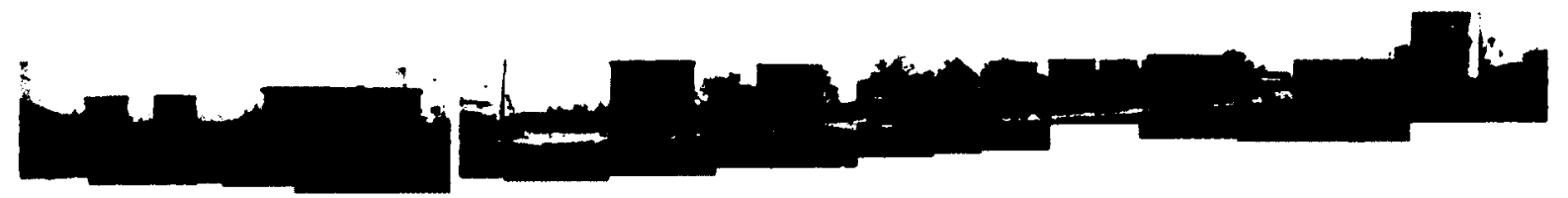

Figure 10 - North Street Elevation of Somerset Street between Preston and Rochester Street (Source: Greg Fung)

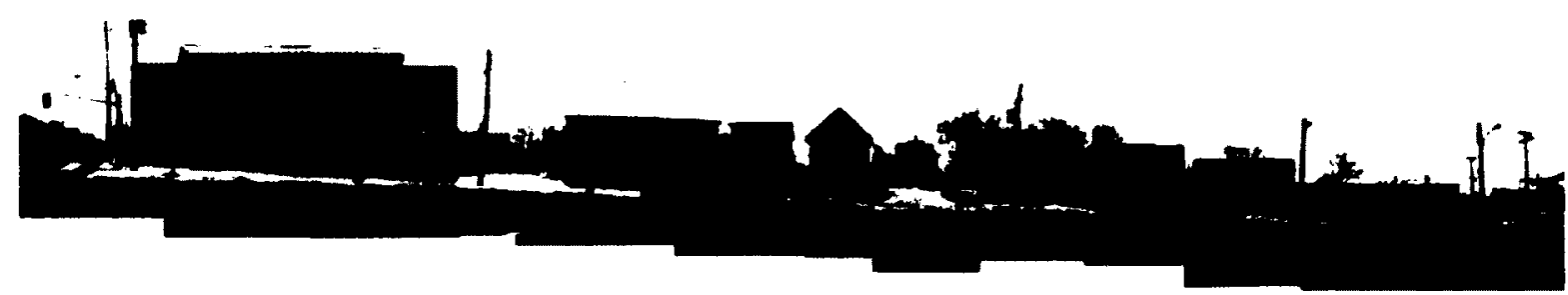

Figure 11 - South Street Elevation of Somerset Street between Preston and Rochester Street (Source: Greg Fung) 


\section{Site 1:}

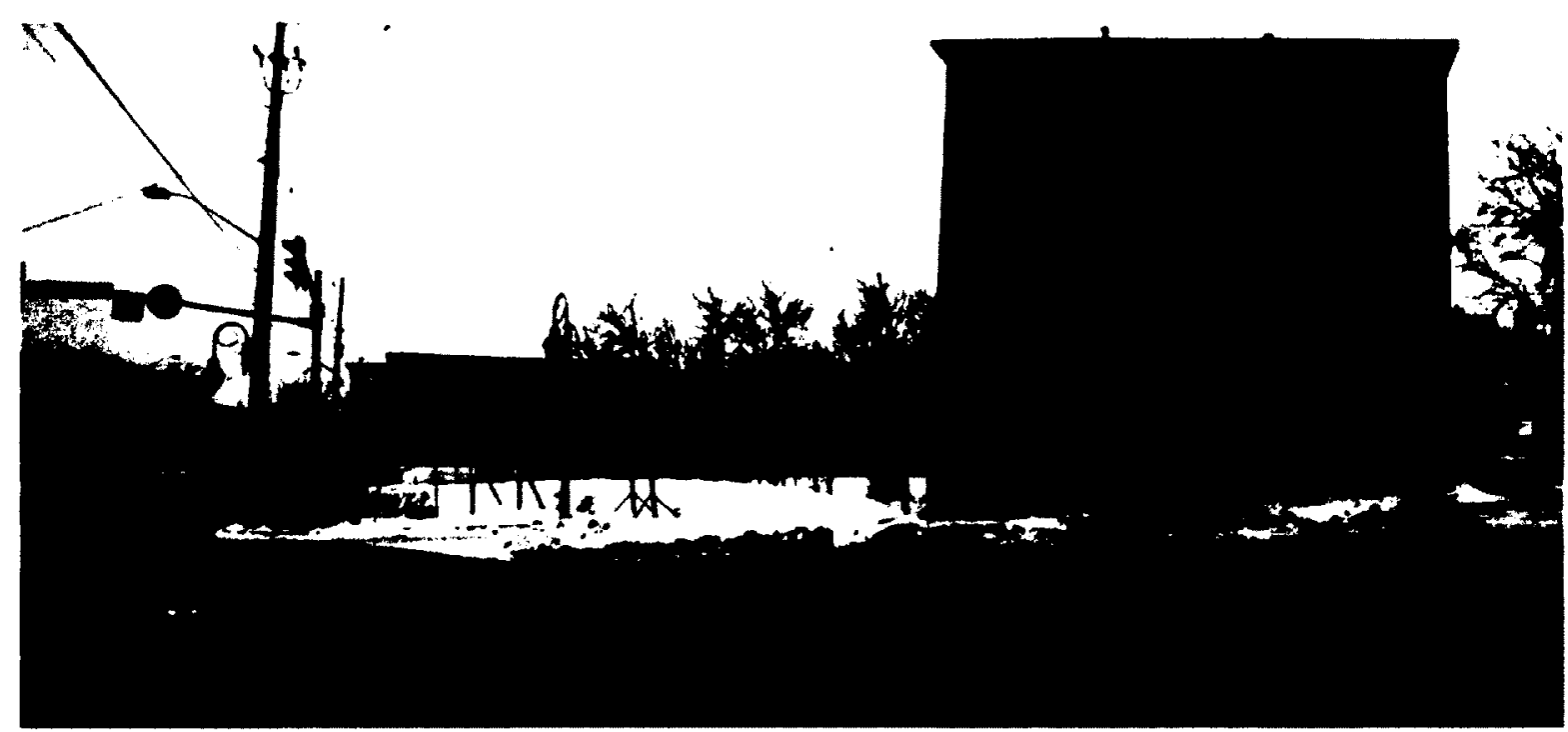

Figure 12 - Site 1 (Source: Greg Fung)

Site 1 is located at the north east corner of the Somerset and Preston Street intersection. There are residences directly to the north and south side of the site. There are Chinese and Italian grocery stores across the street to the west. The Plant Recreation Centre and its historic Plant Bath building are located at the south-west corner of this intersection, diagonally across from the site. There is tire and automobile repair store across the street, south of the site.

Site 1 is chosen as the main site for the project for several reasons. Firstly, site 1 is located at the crossing of the two main streets of Ottawa's Chinatown and Little Italy. It is at the crossroads of two cultural areas in the city: Chinese-Asian and Italian-Western. Secondly, the site is currently empty, there is however a Vietnamese Boat People museum proposed for the site. The project, for this thesis, a new project be on the site 
and discussed below. Thirdly, this area of Somerset Street is in need of rejuvenation. It needs more diversity and density in its programme and services to create a more vibrant street. The proposed project on this lot can be used as a catalyst to encourage more people to visit and more businesses to move into the area. It can also improve the quality of the urban environment through increasing visitors to the area, offering more variety in services and better quality buildings. Fourthly, the site is located diagonally across from the Plant Recreation Centre which provides fitness facilities for various activities such as swimming, weight lifting and aerobics exercises. The centre is a place for neighbourhood residents to be active and to be involved in maintaining good health through exercise. The proposed project for Site 1 should be complementary to the recreation centre and the surrounding buildings by having a program and architecture that positively responds to and adds to the community. 
Site 2:

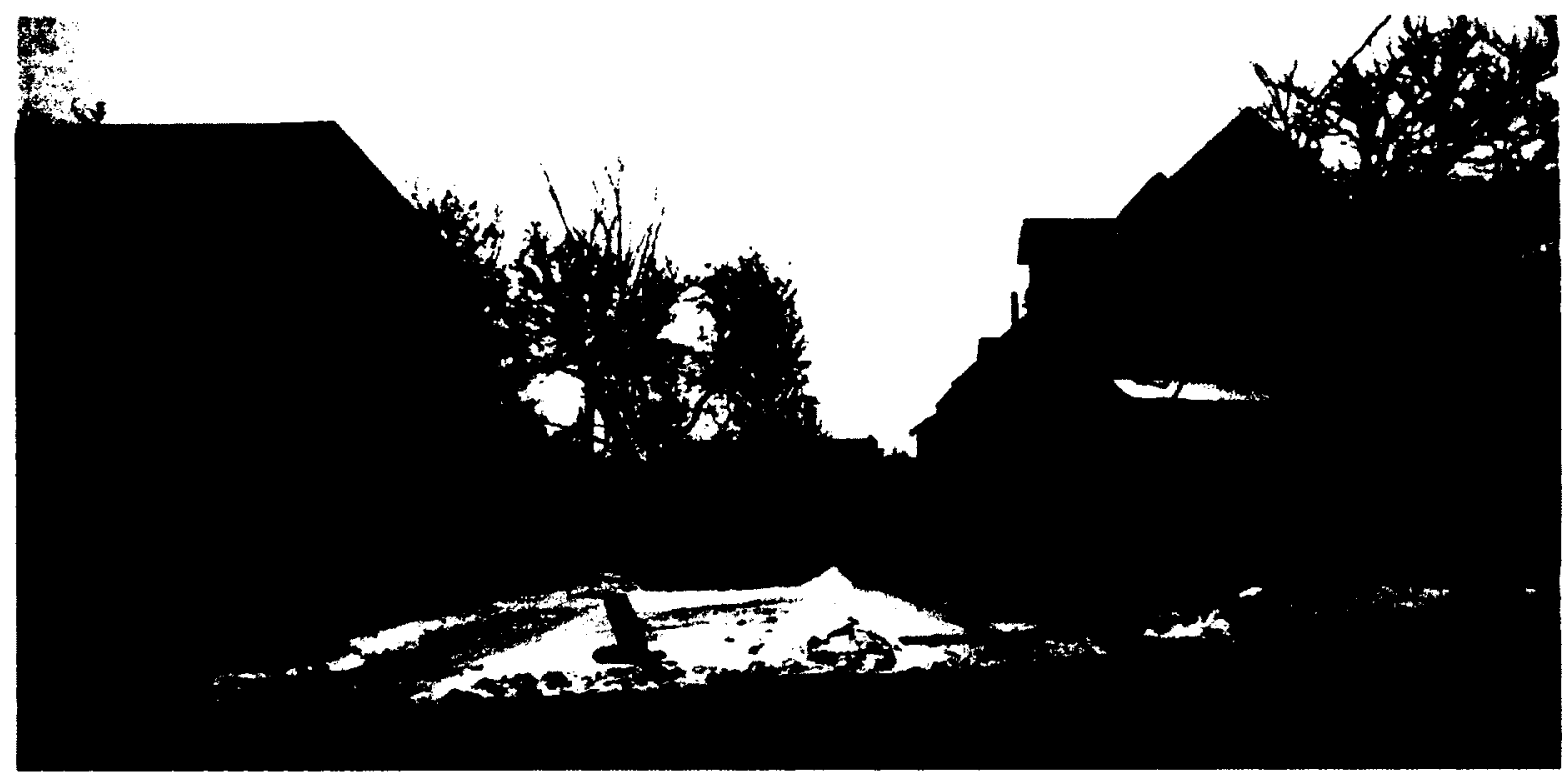

Figure 13 - Site 2 (Source: Greg Fung)

Site 2 is located on the northern side of Somerset Street between Preston and Rochester

Street. It is between two buildings, an acupuncture centre to the west and a Buddhist centre to the east, both buildings have dwellings on the second floors. The lot is currently underdeveloped as an ad-hoc parking lot. 
Site 3:

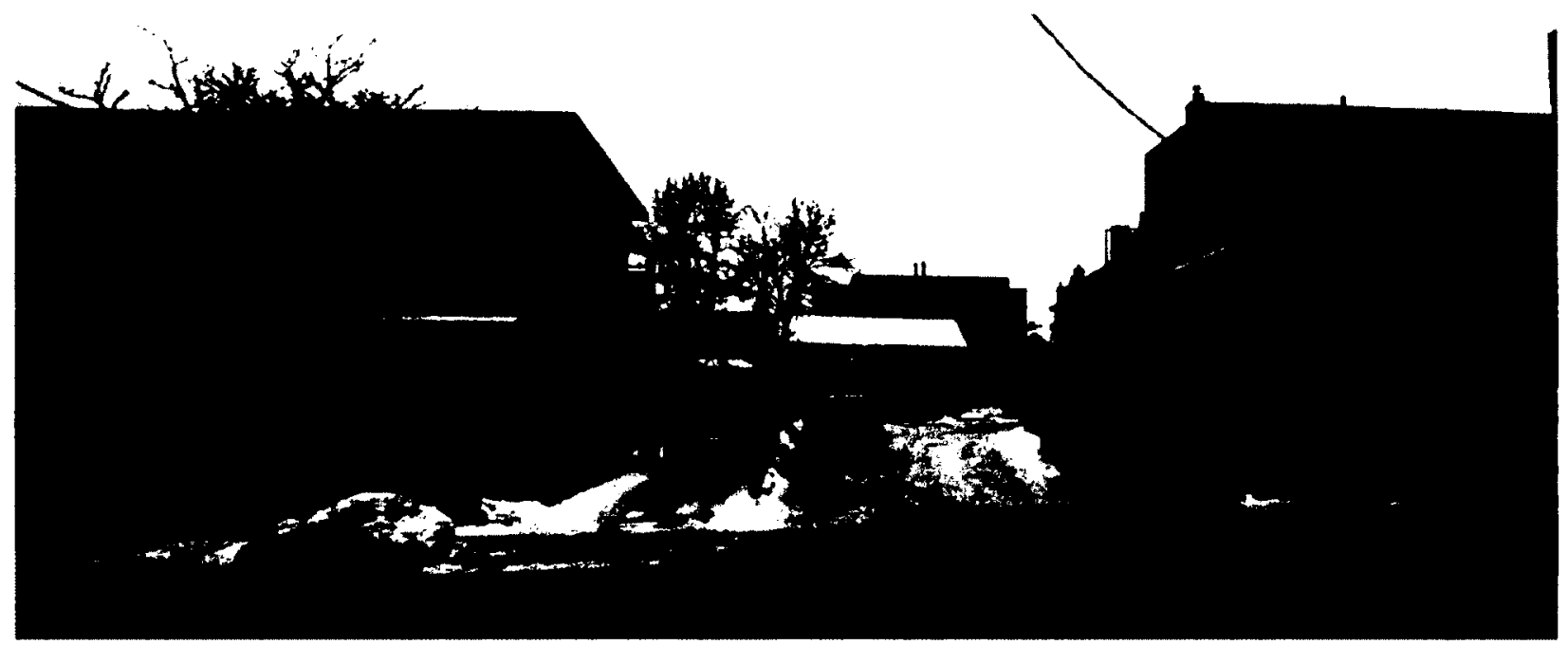

Figure 14 - Site 3 (Source: Greg Fung)

Site 3 is a parking lot for a Vietnamese restaurant. Ottawa's Chinatown contains many Asian restaurants serving Vietnamese, Chinese, Japanese and Korean cuisines. Part of the culture and appeal of this area are the various Asian cuisines. This can be further emphasized through a project that focuses on the Asian cuisines. 
Site 4:

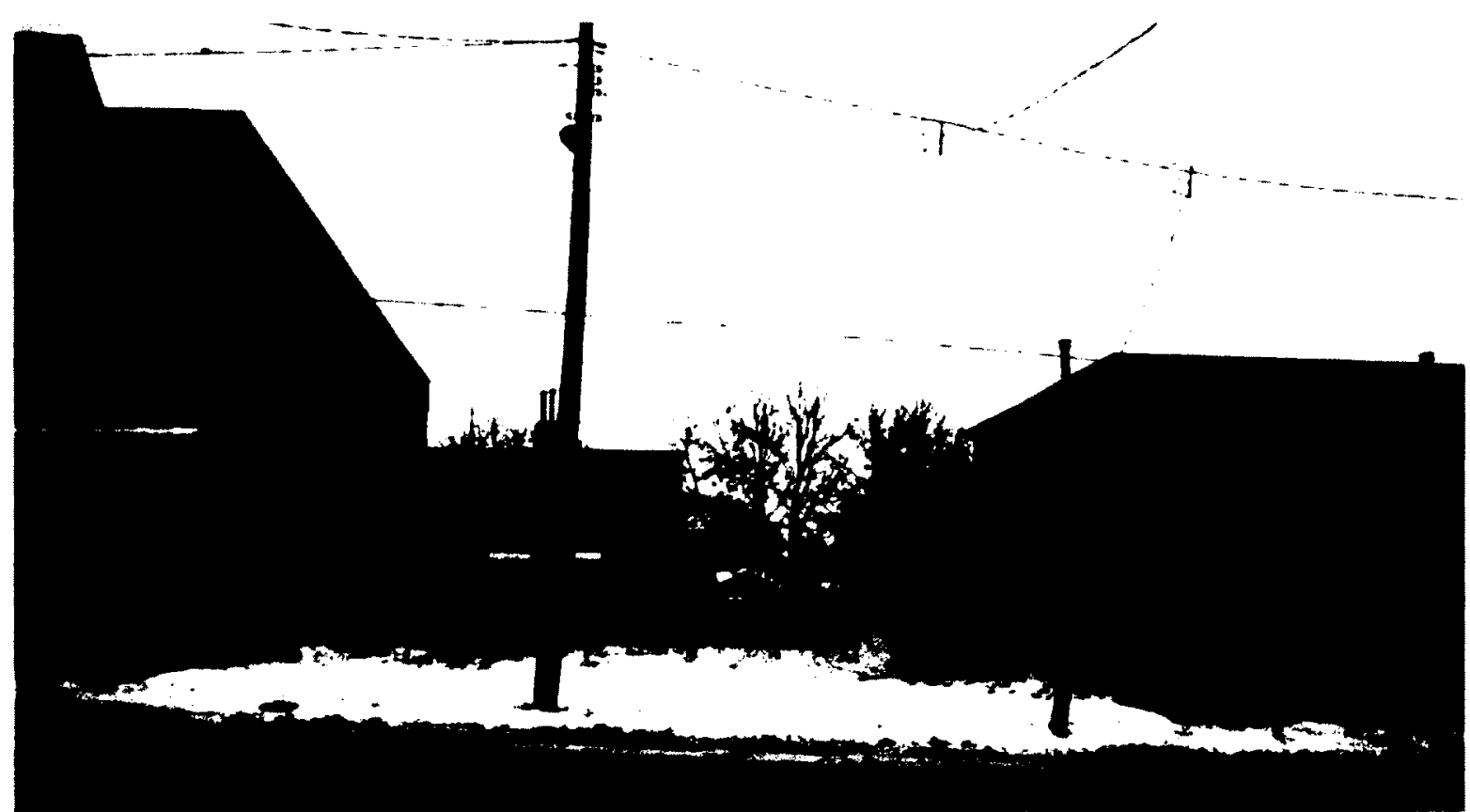

Figure 15 - Site 4 (Source: Greg Fung)

Site 4 is an empty lot located on the south side of Somerset Street, between Rochester and Preston Street. It is bounded by a residential building on the west side, a mixed use (commercial and residential) building and residential buildings on the south side. The mixed use building is too large and jarring for its surroundings. The buildings main entrance on Rochester Street does not face nor engages the Somerset Street; it is set too far back and raised too high from the ground level. 
Site 5:
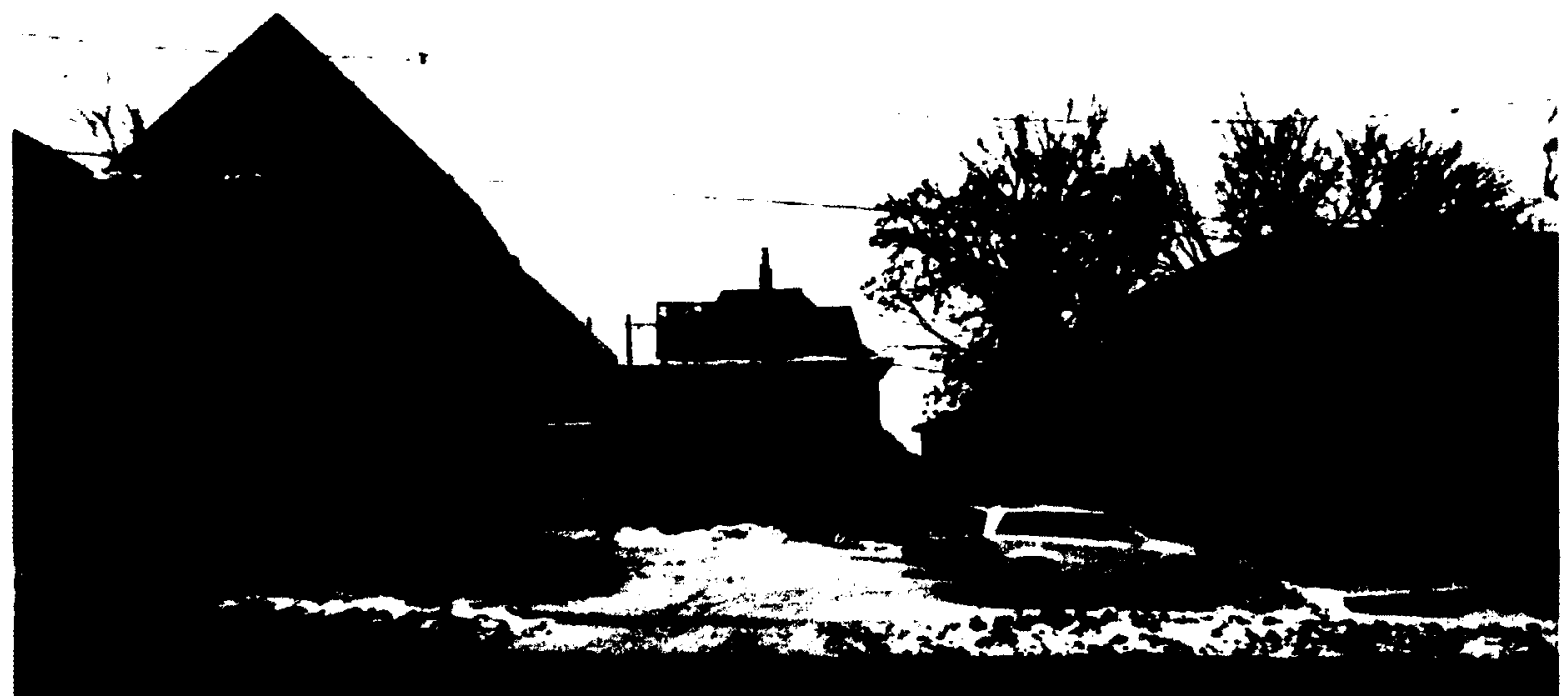

Figure 16 - Site 5 (Source: Greg Fung)

The fifth site is located between a residential building and a driving school. The lot is currently been used as a parking lot. 


\section{Projects}

\section{Intervention 1: Cafe and Clinic}

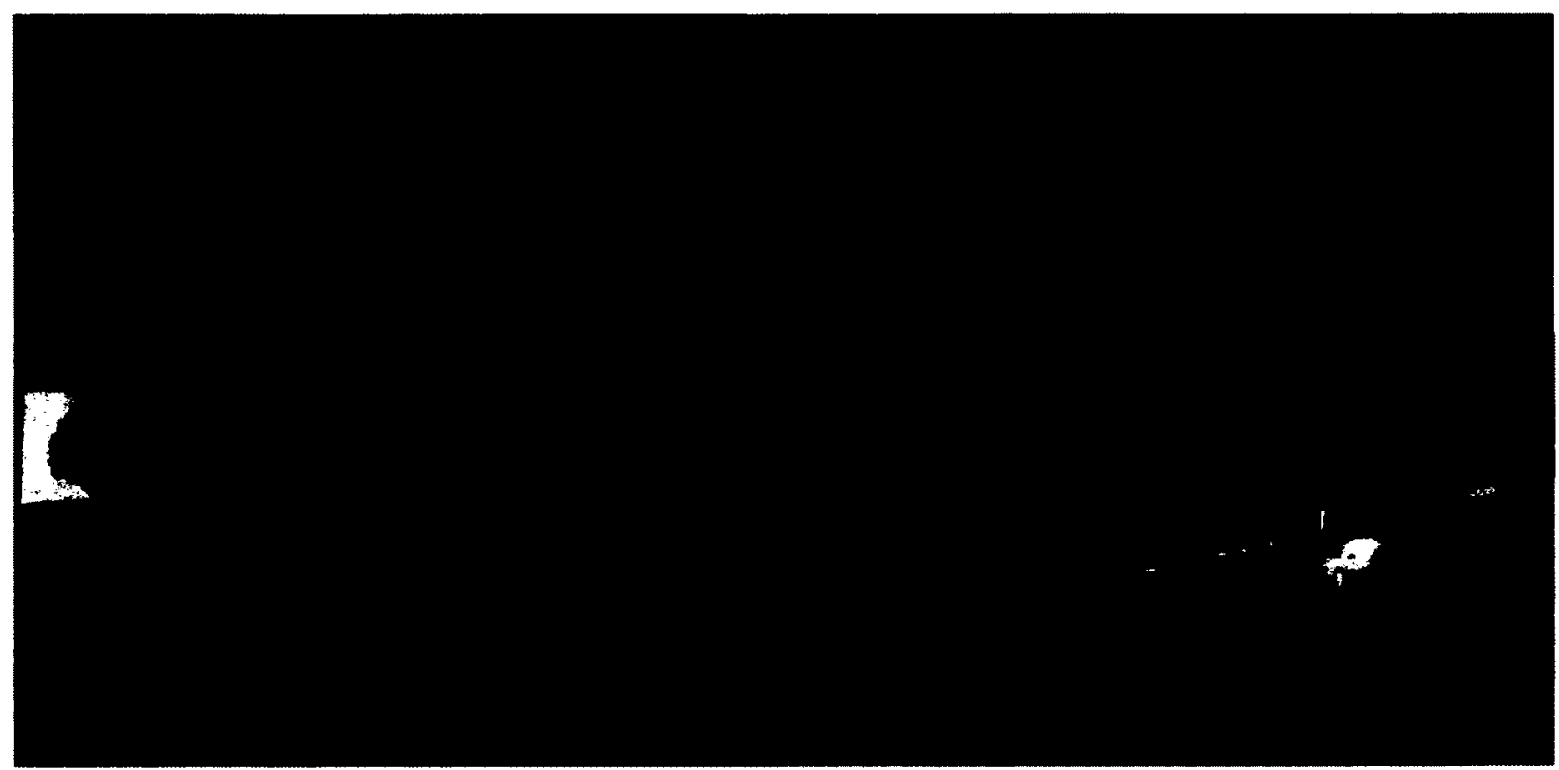

Figure 17 - Cafe \& Physiotherapy Clinic. (Design/Source: Greg Fung; Surrounding Buildings Massing Models Source: City of Ottawa, retrived from Carleton University Library; People, Trees, Automobiles and Cafe Table Source: Google)

The first project is a cafe and physiotherapy centre located on the north-east corner of Somerset and Preston Street (Site 1). The building's programme is complementary to the Plant Recreation Centre diagonally across from it. The cafe gives the people in the neighborhood and those visiting the recreation centre an additional place to gather and socialize. The physiotherapy centre assists the people in the community and the recreation centre patrons by helping them recover and prevent injuries and improve their own physical health. The physiotherapy centre encourages development of new doctors and therapists within the city. It has two small bachelor suites on the third floor for new intern doctors and therapist to stay during their internship at the centre. The live in residences makes it easier for the interns to be involved in the community and be part of 
the community. The interns work with the doctors, therapists and patients to provide assistance and to gain practical experience.

The panels on the roof are made from weathering steel which is also known as Cor-ten. This type of steel will form a protective rust coating on its surface over time. The chemical composition of the steel allows the coating to remain on the weathering steel instead of the coating detaching. The weathering steel is also used for the drainage channel in front of face of the atrium near the entrance. It collects the rain water from the concave roof and channels it into a cistern for reuse in the toilets and for watering plants. The weathering steel in the channel is coated with an additional protective coating to prevent further corrosion due to increased water exposure. The exterior walls are clad in a dark grey brick. The canopy extending above the sidewalk next to the cafe is made of laminated fritted glass with solar panels inlaid between the sheets of glass. The glass panels on the canopy are supported with dark maroon coloured steel beams. The surrounding panels on the exterior of the building between first and second floors are laminated wood panels with a protective coating. The windows on the building are made from triple plane glass with a low-e coating. Some windows have an operable opening to provide natural ventilation. The wood louvers between the second and third floor provide shade and privacy.

The main structure of the building is constructed with glue laminated timber (Glulam) made from Spruce-Fir. The Glulam beam and post are connected with bolts and shear plates. The flooring is composed of cross laminated timber (CLT) with a thin finishing 
layer of concrete supported on Glulam joist. The fire escape exit stairwell core is constructed with insulated concrete. The stairwell also acts as a shear wall for the building. The foundation is made of concrete.

The cafe and atrium are located on the ground floor. The cafe can be opened to the street with its mobile wall. The perimeter of the building is curved in and out of the street, to creating pockets of spaces to be used for sitting, gathering and talking. The cafe on the ground floor is entered from the vestibule in the lobby. The entrance vestibule connects the three storey atrium space and waiting area for the physiotherapy centre. The patients wait in a sunlit space with plants before walking up the stairs or elevator to the second floor physiotherapy centre. ${ }^{161}$

The Physiotherapy Centre is located on the second floor of the building. It contains therapy tables arranged around two elliptical doctor's offices. During the day the space is lit with natural light coming in from the large windows facing the street. There is also has a wet room for hydrotherapy.

The third floor of the building contains two bachelor suites with a kitchen, bathroom, an office, a small roof deck and garden. The two bachelor suites are for doctors, physiotherapist or medical interns to stay in on a temporary basis.

\footnotetext{
${ }^{161}$ Refer to appendix for plans, elevations, sections and additional images of the cafe $\&$ clinic.
} 


\section{Intervention 2: Market}

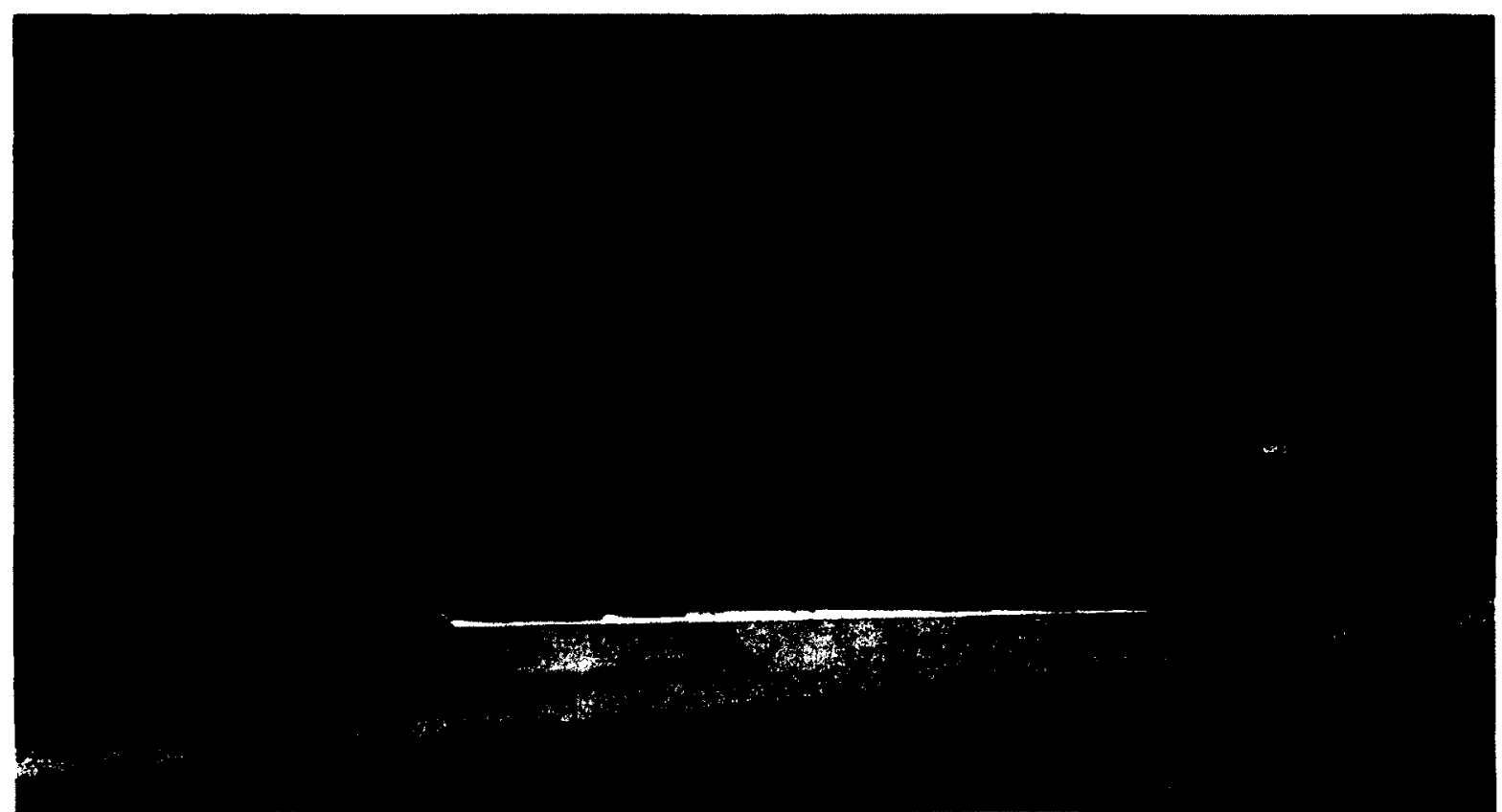

Figure 18 - Market. (Design/Source: Greg Fung; Surrounding Buildings Massing Models Source: City of Ottawa retrieved from Carleton University Library; People, Trees, Automobiles and Cafe Table Source: Google)

The second architectural project is an open air market along the north side of Somerset Street. Open markets or stalls are commonly found in Chinatowns and Asian countries depending on the climate. The project proposes an open air pavilion with individual secured stalls for vendors. In the cold winter, the site can be used as a covered parking lot. $^{162}$

The structure of the building is made from coated Glulam beams and posts with steel fasteners and steel rods for the cross bracing. The wood louvers are in upper sections of the structures to provide shade while allowing for ventilation. The roof is covered with

\footnotetext{
${ }^{162}$ Refer to figure 32 in the appendix for an interior view and elevations of the market.
} 
solar panels in between sheets of laminated glass. The solar panels generate and store electricity in batteries for use in night, the space is illuminated with suspended lights using the stored electricity. Rain water is collected from the roof during rainfall and is stored in cisterns for later use. The individual stalls are made from steel and painted in various colors. The hinged cover provides shade through its slotted panels. The counter and the vendor's merchandise can be rolled into the stall and the cover can be folded down and locked overnight.

The market can engage the street and revitalizes it. The market generates interest in the area with it changing multiple vendors. It is open to the street and provides shade from the sun. It is encourages socializing with the open space, the concentration of vendors and visitors. 


\section{Intervention 3: Cooking School}

Figure 19 - Cooking School. (Design/Source: Greg Fung; Surrounding Buildings Massing Models Source: City of Ottawa retrieved from Carleton University Library; People, Trees, Automobiles and Cafe Table Source: Google)

The remaining projects, three to five, are proposals for potential uses of the remaining empty lots on the section of Chinatown on Somerset Street between Preston Street and Rochester Street. The third project is a cooking school featuring the diverse cuisines from the various Asian cultures in the community. The materials for the cladding are red brick and wood panels to have it relate to materials uses on other buildings in the neighbourhood. It has large windows to provide visibility to the street of the activities within the building and to enhance interaction. 
Figure 20 - Commercial and Residential Units. (Design/Source: Greg Fung; Surrounding Buildings Massing Models Source: City of Ottawa retrieved from Carleton University Library; People, Trees, Automobiles and Cafe Table Source: Google)

The forth proposal is a commercial and residential building along the south side of

Somerset Street. The project is composed of three compact, mixed use units with retail on the ground floor and residences on the second floor. The second floor is accessed through a stairwell in between the buildings. This combination of the two uses can lower the cost of the lease of lower floor for business and rent of the upper floor. The intention is to have space for small start-up business and provide affordable housing to the community. The building is clad in brick, in colors found on the neighboring buildings and wood panels. Sitting spaces are placed in front of the building. 


\section{Intervention 5: Gallery Space / Community Centre}

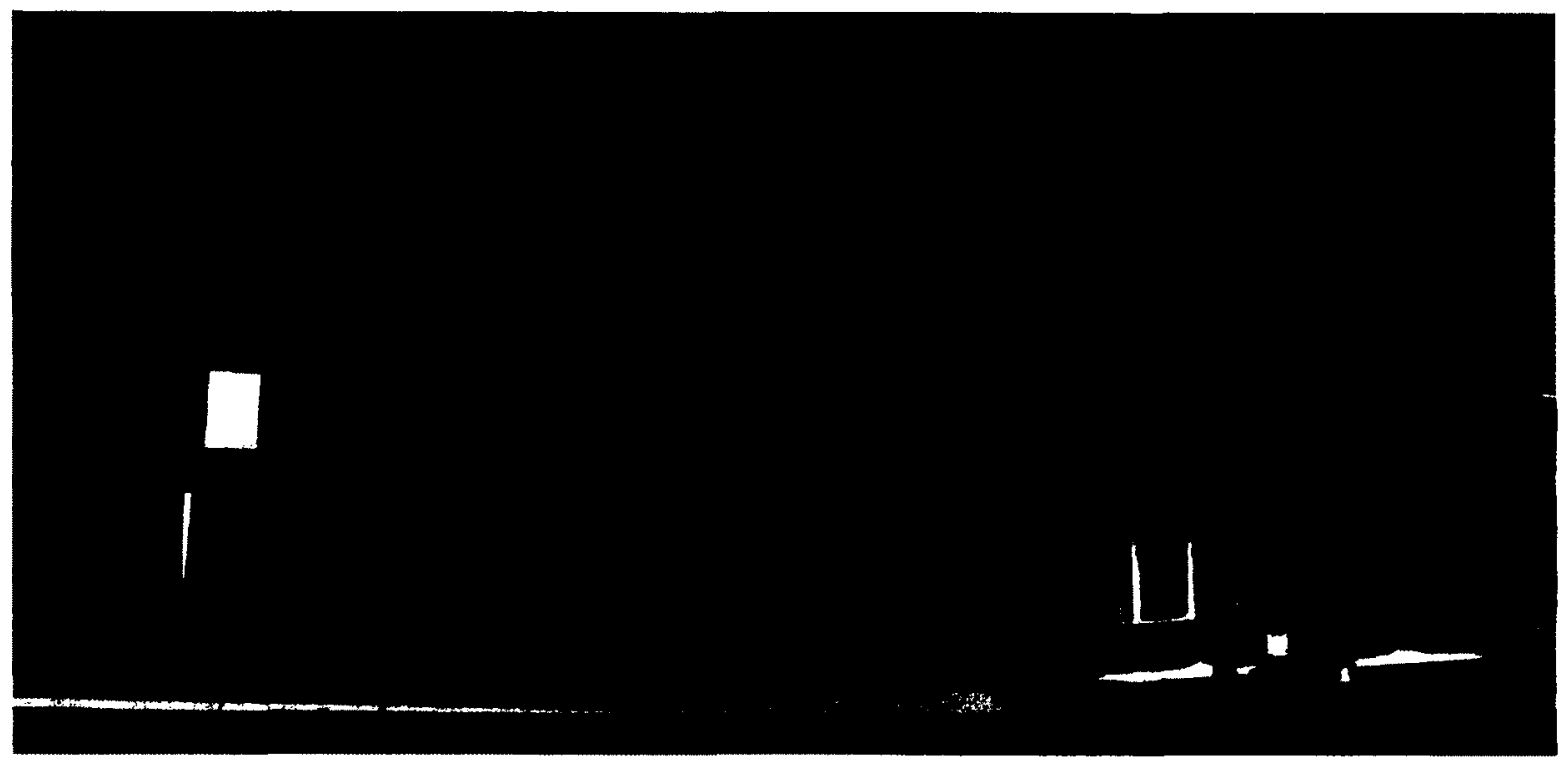

Figure 21 - Gallery Space / Community Centre. (Design/Source: Greg Fung; Surrounding Buildings Massing Models Source: City of Ottawa retrieved from Carleton University Library; People, Trees, Automobiles and Cafe Table Source:: Google)

The fifth proposal along Somerset Street is related to cultural representation. The gallery space provides an opportunity to showcase the cultural artifacts or representations of the various cultures of the communities along Somerset Street. It has an open floor plan and can be used for other purposes such as community meetings, dinner receptions, theater space, etc.

The front of the building can be opened to the street. The overhead door can be completely opened so that the building can be an outdoor stage and engage the street. The stepped benches are for people to sit in the street or it can be part of the stage. The sides and back of the building is clad in colour metal panels. The building's programme engagement with the street can contribute the revitalization of the street and the area. 


\section{Conclusion}

A more holistic approach to designing architecture can be achieved through understanding how the body responds to the built environment and through developing a systemic prognosis in response to architectural or urban issues. The thesis studied how people respond to the built environment and examined prognosis and acupuncture to use it as an analogy for design. The thesis also analyzed architecture precedents and developed a series of architecture projects in response to the research and site.

The environment is perceived by our senses and interpreted by through our memory, emotions and imagination. Our response to the environment is individual and exclusive to ourselves. However architects and designers can indirectly influence the possibility of a response or activity to happen in the space, through purposeful design. A design can either positively or negatively affect a person's health. Yet our health is primarily determined by our mind, our body, the activities we choose to do and the medical care that we receive.

Traditional Chinese Medicine were compared in terms of its analytical and empirical methodologies. The medical term, prognosis, is defined as a way of examining the whole, the past and present architectural issues and developing a holistic response. Acupuncture is used as an analogy in Urban Acupuncture, where architectural interventions are placed with in the neighborhood to revitalize the area. 
The thesis project examined the history and current conditions of Ottawa's Chinatown along Somerset Street. Five sites where chosen for five architecture interventions. Those projects are: cafe \& clinic, market, cooking school, retail stores / residences and a gallery. These projects are a response to the current conditions and the projected future of the street. They help revitalize their individual site, street, neighbourhood and, to a limited extent, the city. 
Appendix: Plans, Sections, Elevations \& Structure

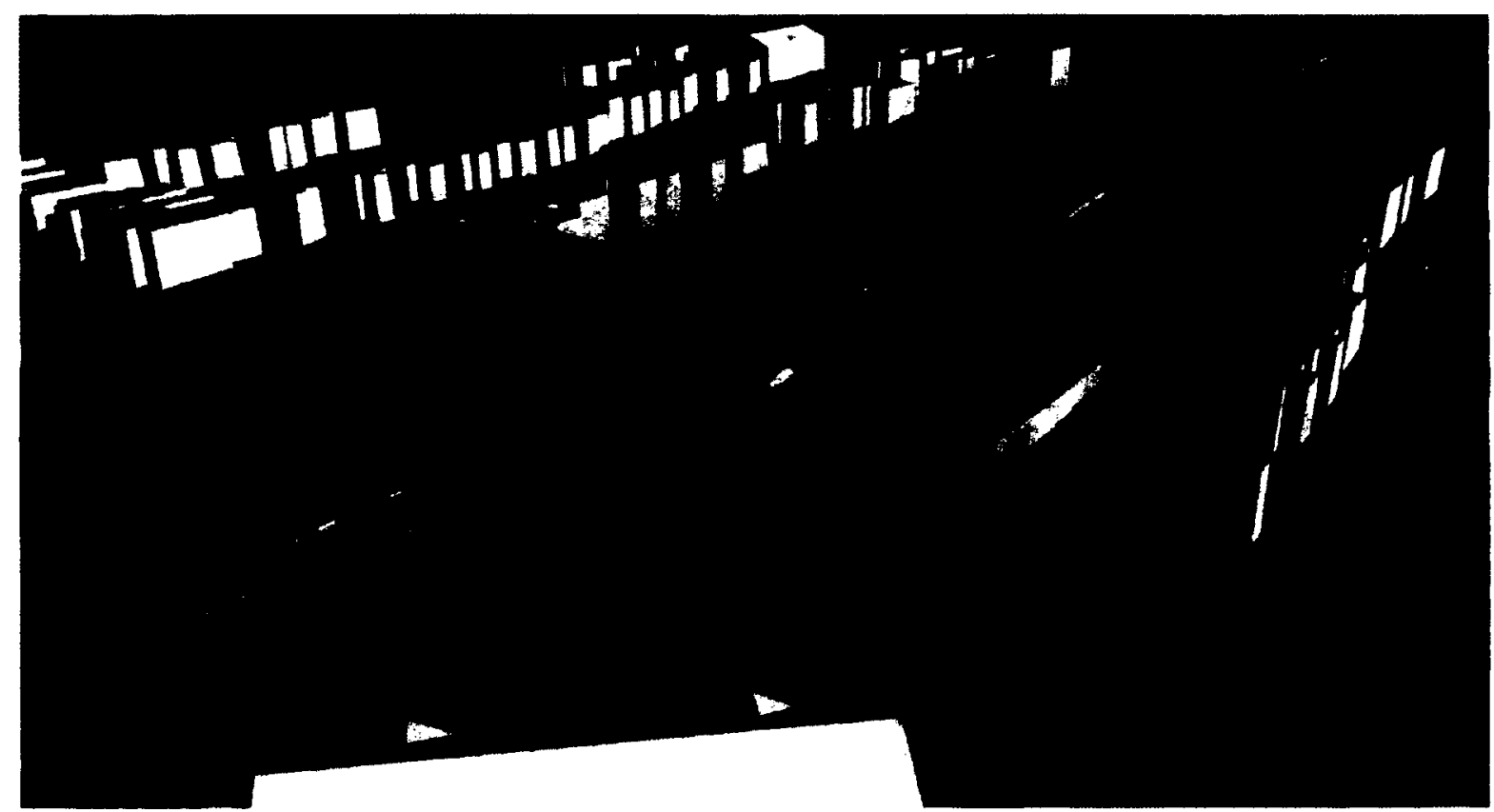

Figure 22 - North-East View of Somerset Street Model (Design/Source: Greg Fung; Surrounding Buildings Massing Models Source: City of Ottawa retrieved from Carleton University Library; People, Trees, Automobiles and Cafe Table Source: Google)

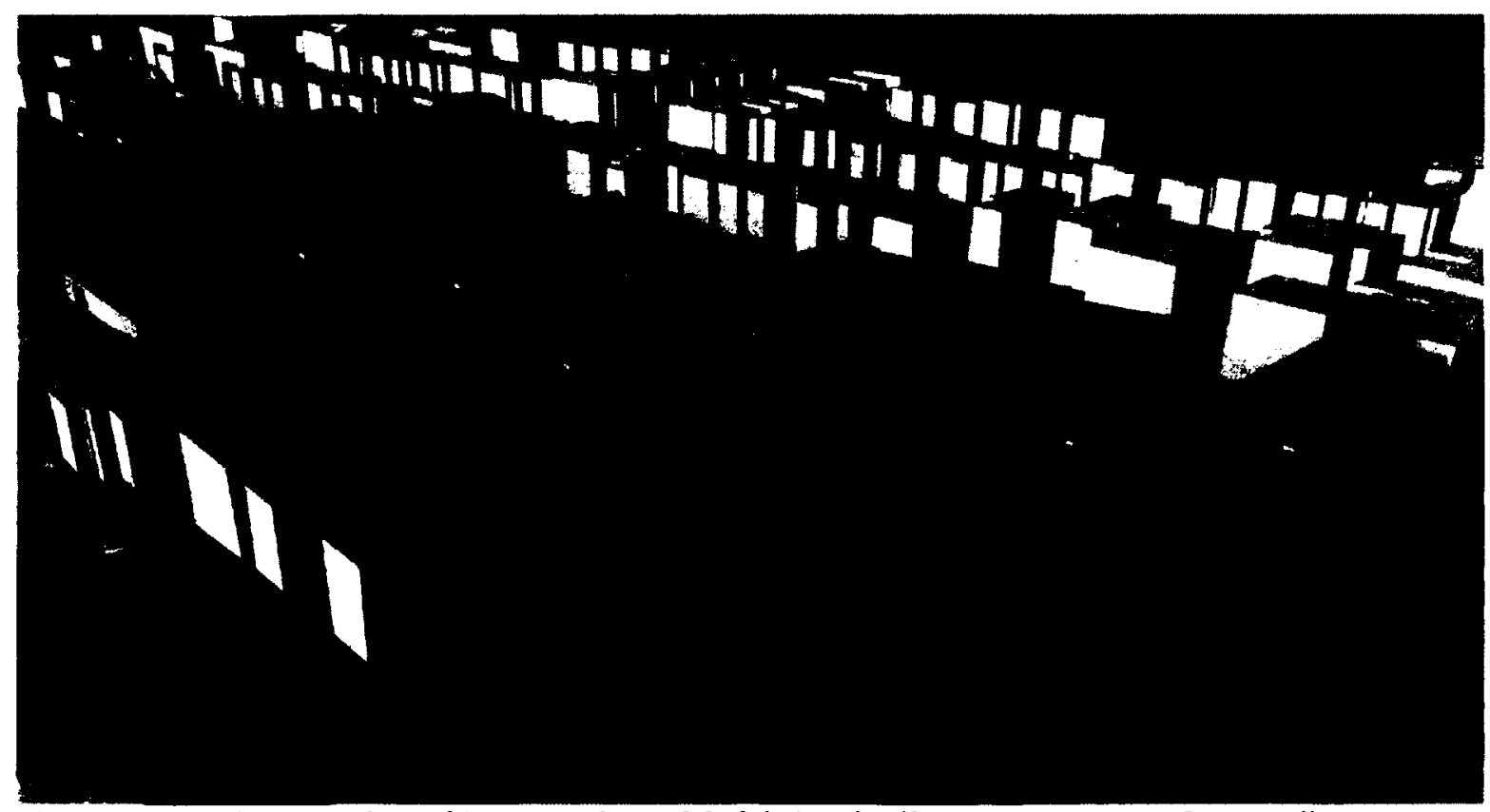

Figure 23 - North-West View of Somerset Street Model (Design/Source: Greg Fung; Surrounding Buildings Massing Models Source: City of Ottawa retrieved from Carleton University Library; People, Trees, Automobiles and Cafe Table Source: Google) 


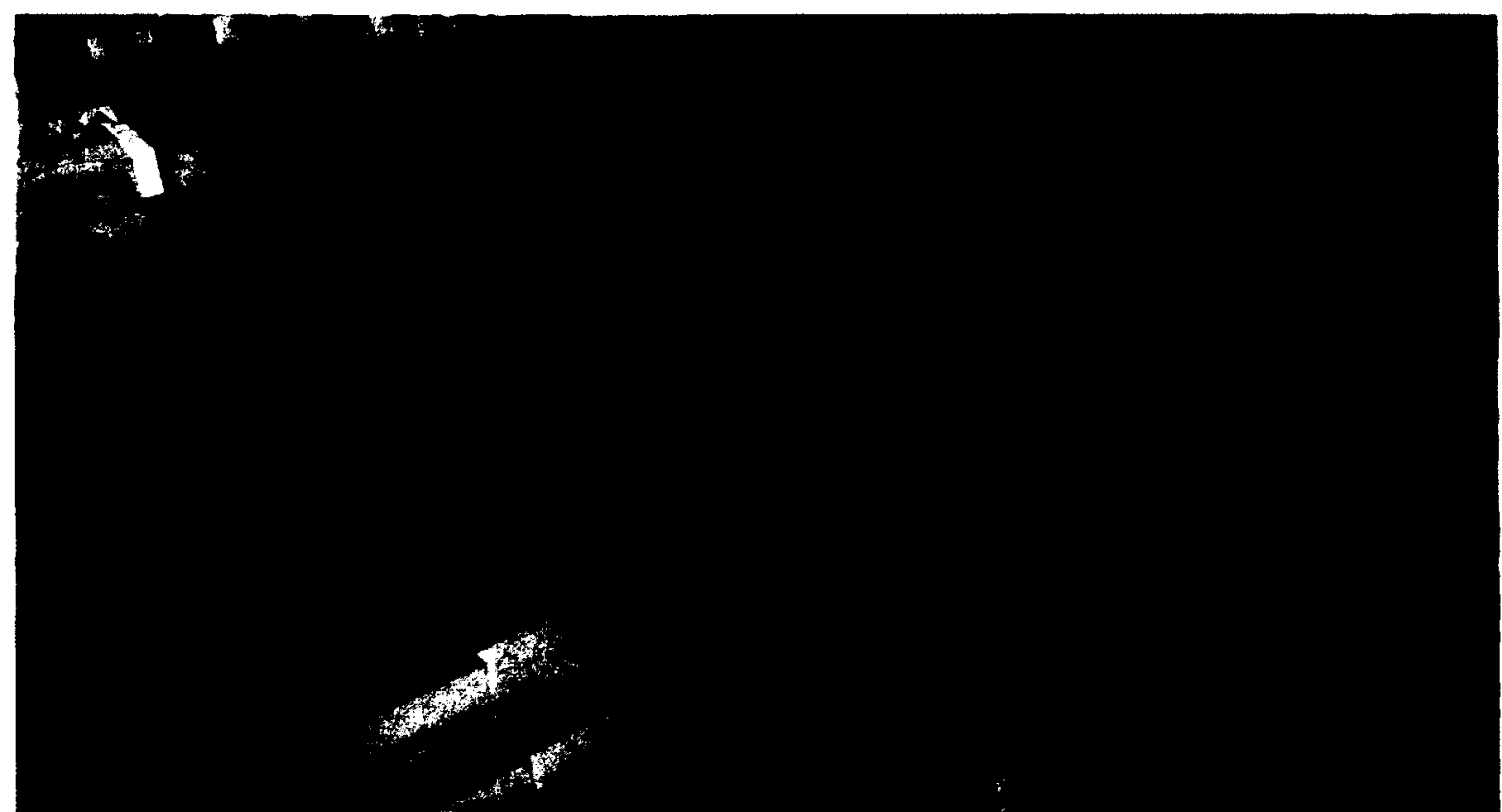

Figure 24 - South-West View of Somerset Street Model (Design/Source: Greg Fung; Surrounding Buildings Massing Models Source: City of Ottawa retrieved from Carleton University Library; People, Trees, Automobiles and Cafe Table Source: Google)

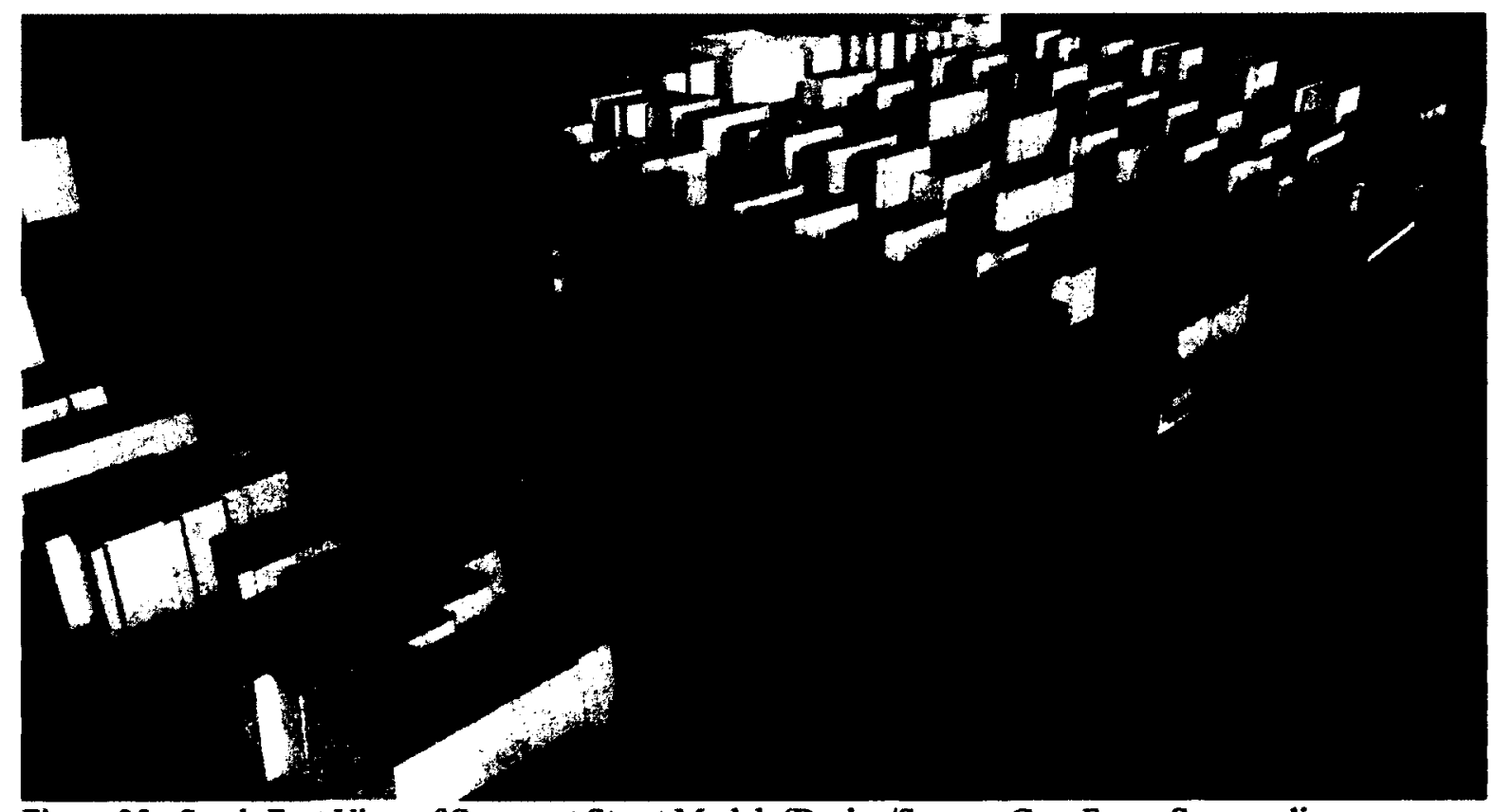

Figure 25 - South-East View of Somerset Street Model (Design/Source: Greg Fung; Surrounding Buildings Massing Models Source: City of Ottawa retrieved from Carleton University Library; People, Trees, Automobiles and Cafe Table Source: Google) 
Figure 26 - South-East View of Cafe \& Clinic (Design/Source: Greg Fung; Surrounding Buildings Massing Models Source: City of Ottawa retrieved from Carleton University Library; People, Trees, Automobiles and Cafe Table Source: Google)

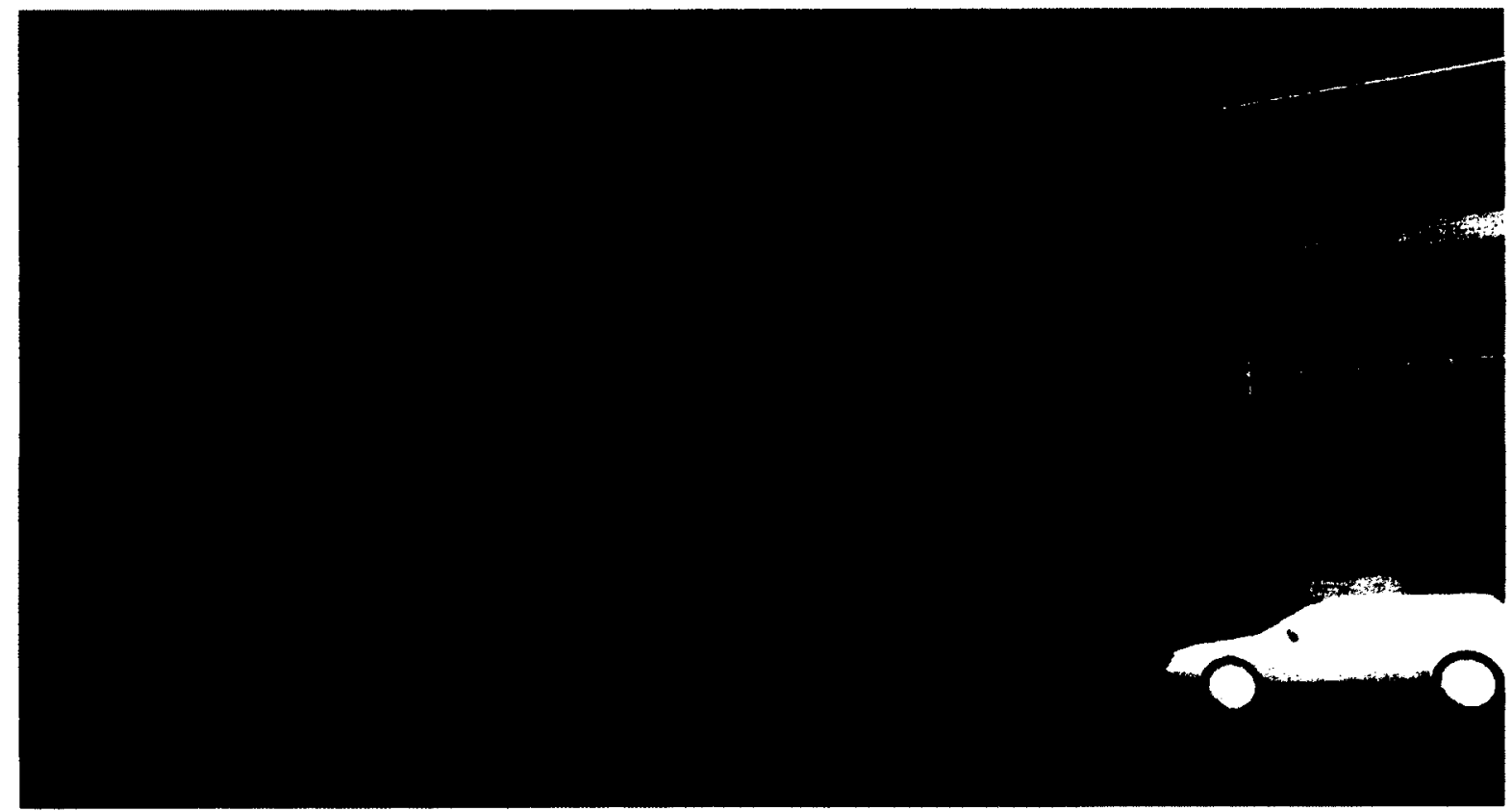

Figure 27 - North-East View of Cafe \& Clinic (Design/Source: Greg Fung; Surrounding Buildings Massing Models Source: City of Ottawa retrieved from Carleton University Library; People, Trees, Automobiles and Cafe Table Source: Google) 
Figure 28 - South Elevation Cafe \& Clinic (Design/Source: Greg Fung; Surrounding Buildings Massing Models Source: City of Ottawa retrieved from Carleton University Library; People, Trees, Automobiles and Cafe Table Source: Google)

Figure 29 - West Elevation of Cafe \& Clinic (Design/Source: Greg Fung; Surrounding Buildings Massing Models Source: City of Ottawa retrieved from Carleton University Library; People, Trees, Automobiles and Cafe Table Source: Google) 
Figure 30 - North Elevation of Cafe \& Clinic (Design/Source: Greg Fung; Surrounding Buildings Massing Models Source: City of Ottawa retrieved from Carleton University Library; People, Trees, Automobiles and Cafe Table Source: Google)

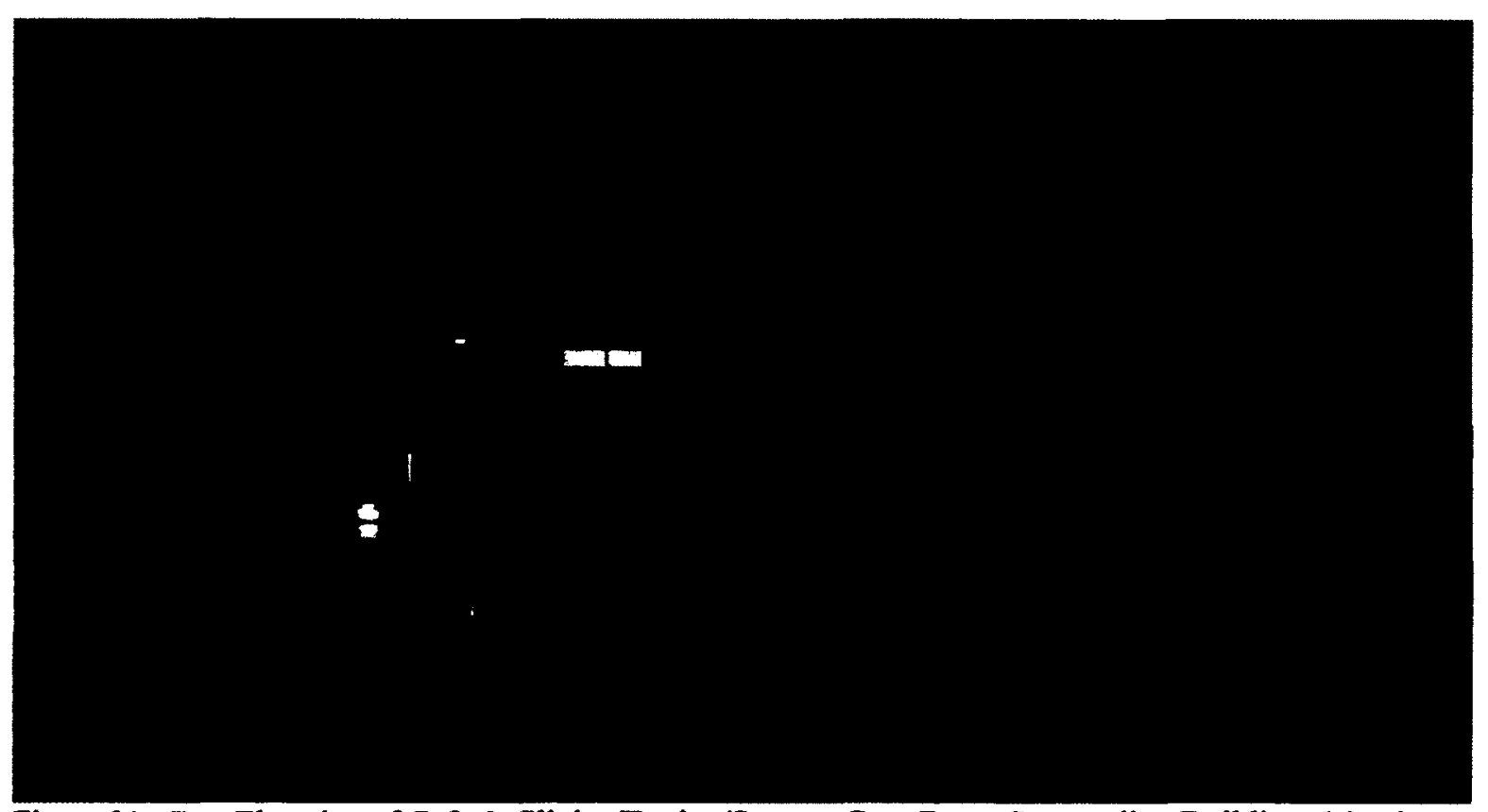

Figure 31 - East Elevation of Cafe \& Clinic (Design/Source: Greg Fung; Surrounding Buildings Massing Models Source: City of Ottawa retrieved from Carleton University Library; People, Trees, Automobiles and Cafe Table Source: Google) 


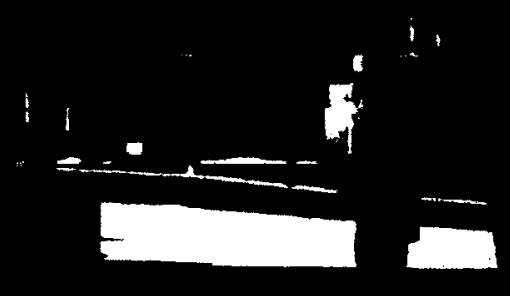

Figure 32 - Interior View of Market (Design/Source: Greg Fung; Surrounding Buildings Massing Models Source: City of Ottawa retrieved from Carleton University Library; People, Trees, Automobiles and Cafe Table Source: Google)

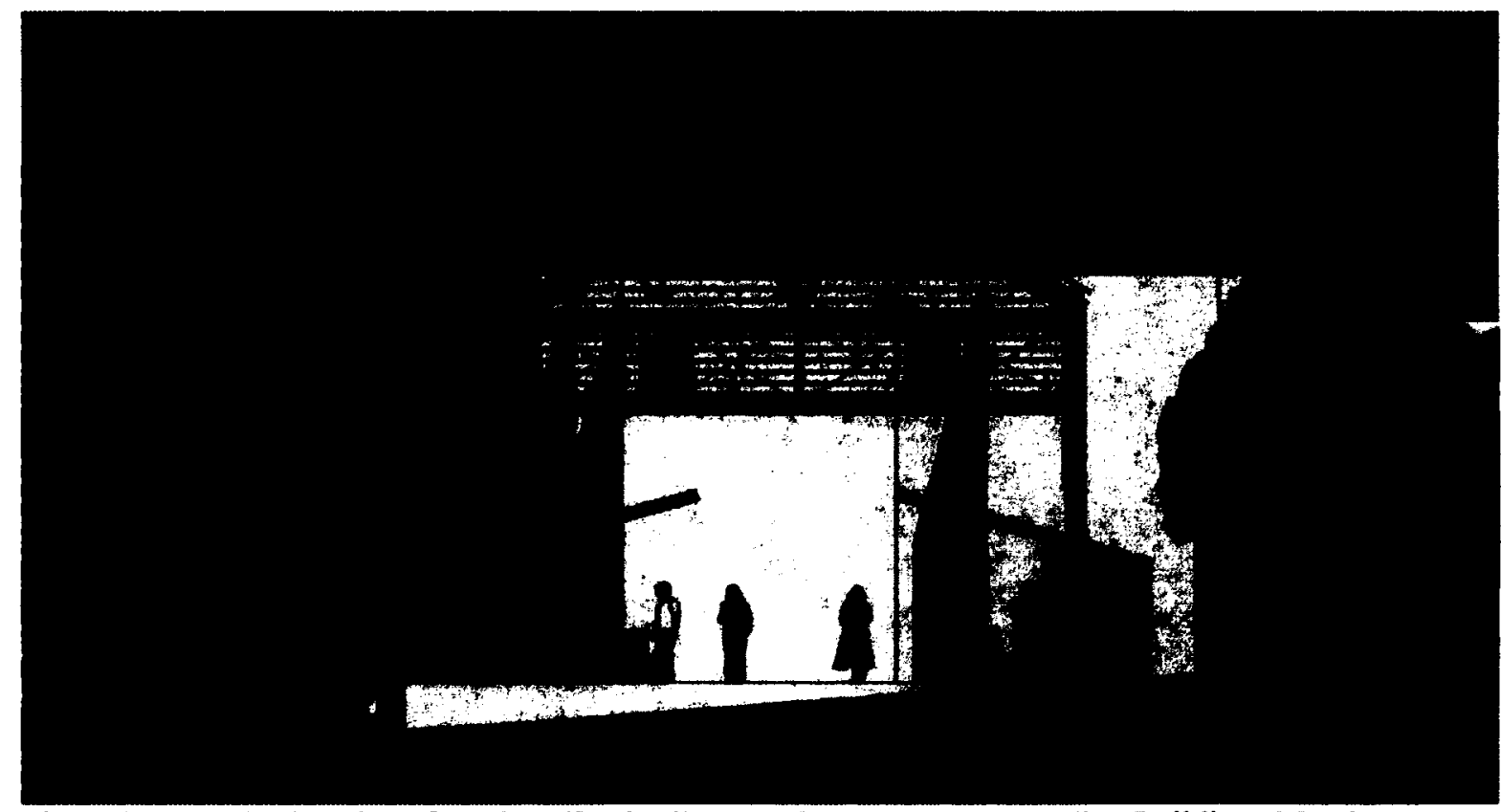

Figure 33 - South Elevation of Market (Design/Source: Greg Fung; Surrounding Buildings Massing Models Source: City of Ottawa retrieved from Carleton University Library; People, Trees, Automobiles and Cafe Table Source: Google) 
Figure 34 - East Elevation of Market (Design/Source: Greg Fung; Surrounding Buildings Massing Models Source: City of Ottawa retrieved from Carleton University Library; People, Trees, Automobiles and Cafe Table Source: Google)

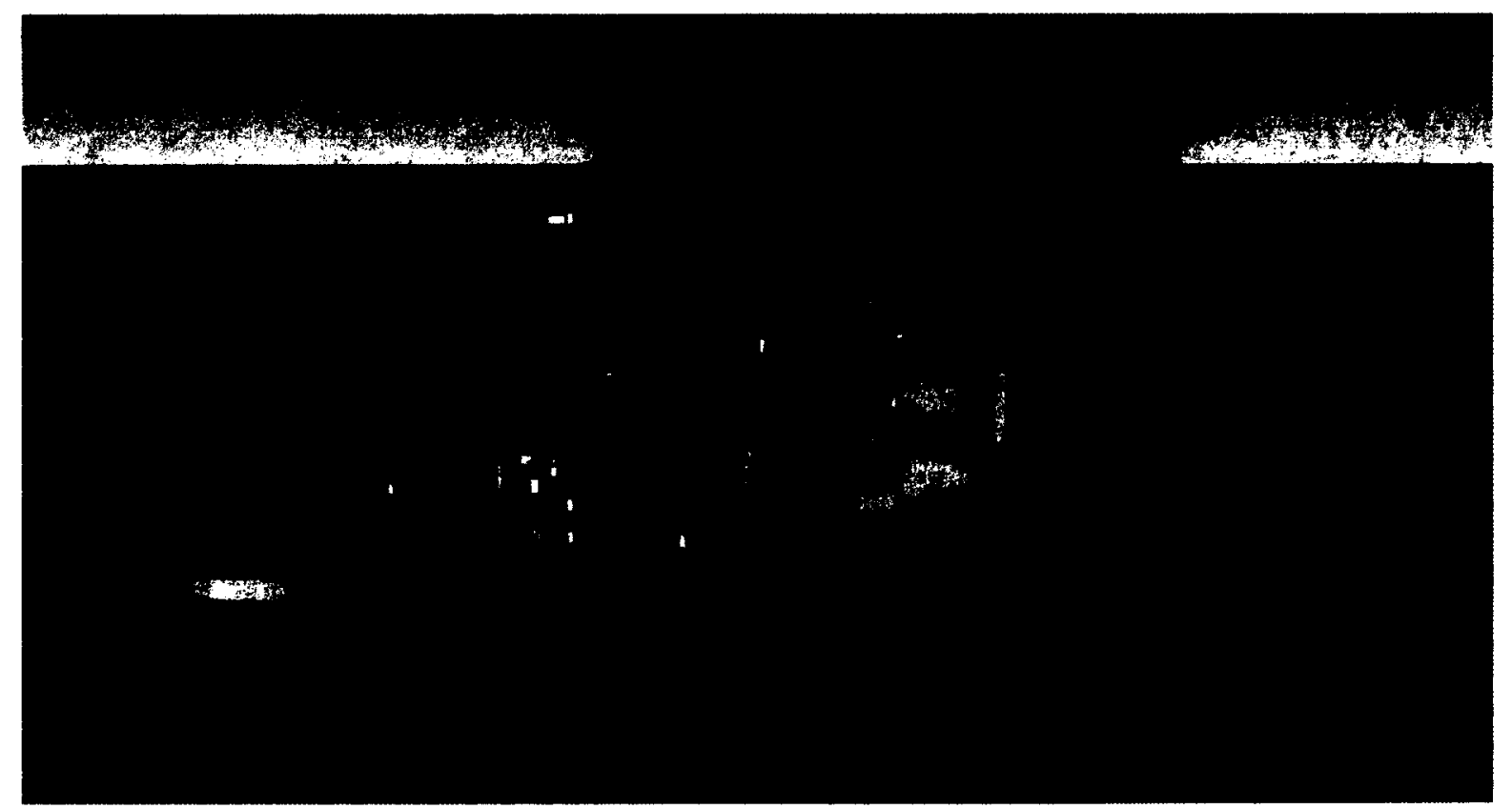

Figure 35 - Section of Cafe \& Clinic (Design/Source: Greg Fung; Surrounding Buildings Massing Models Source: City of Ottawa retrieved from Carleton University Library; People, Trees, Automobiles and Cafe Table Source: Google) 


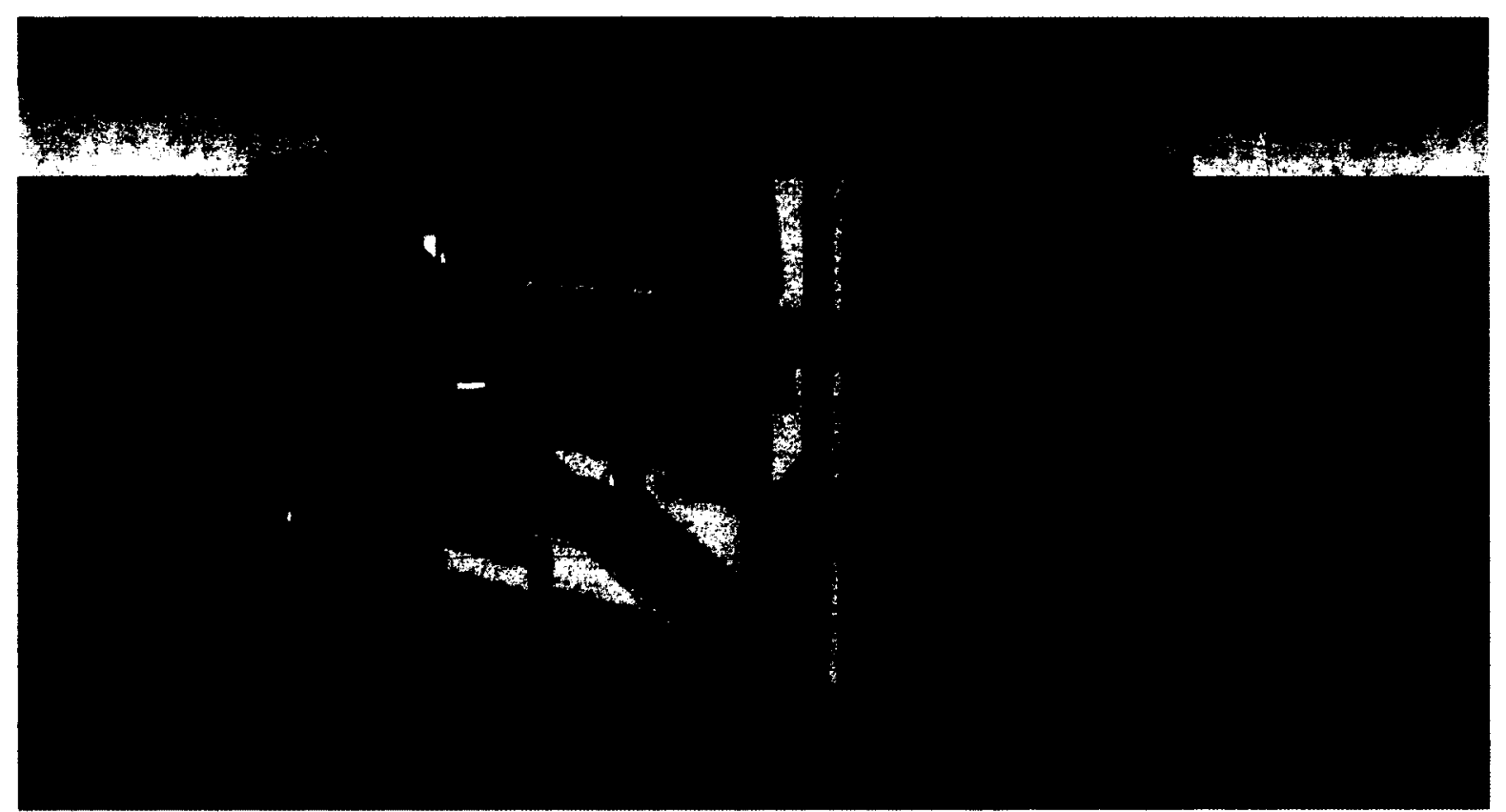

Figure 36 - Section of Cafe \& Clinic (Design/Source: Greg Fung; Surrounding Buildings Massing Models Source: City of Ottawa retrieved from Carleton University Library; People, Trees, Automobiles and Cafe Table Source: Google)

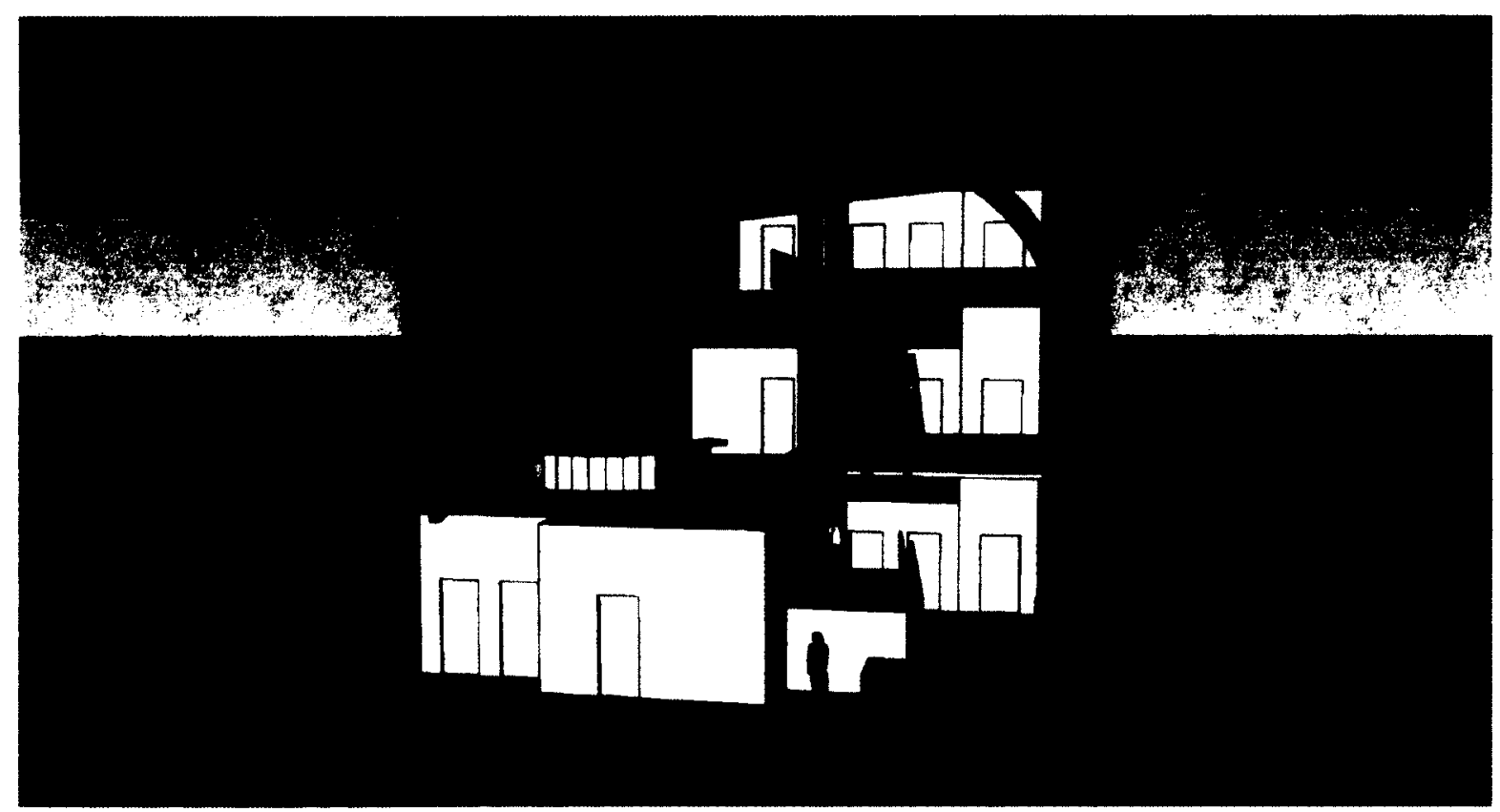

Figure 37 - Section of Cafe \& Clinic (Design/Source: Greg Fung; Surrounding Buildings Massing Models Source: City of Ottawa retrieved from Carleton University Library; People, Trees, Automobiles and Cafe Table Source: Google) 
Figure 38 - Structure of Cafe \& Clinic (Design/Source: Greg Fung; Surrounding Buildings Massing Models Source: City of Ottawa retrieved from Carleton University Library; People, Trees, Automobiles and Cafe Table Source: Google) 


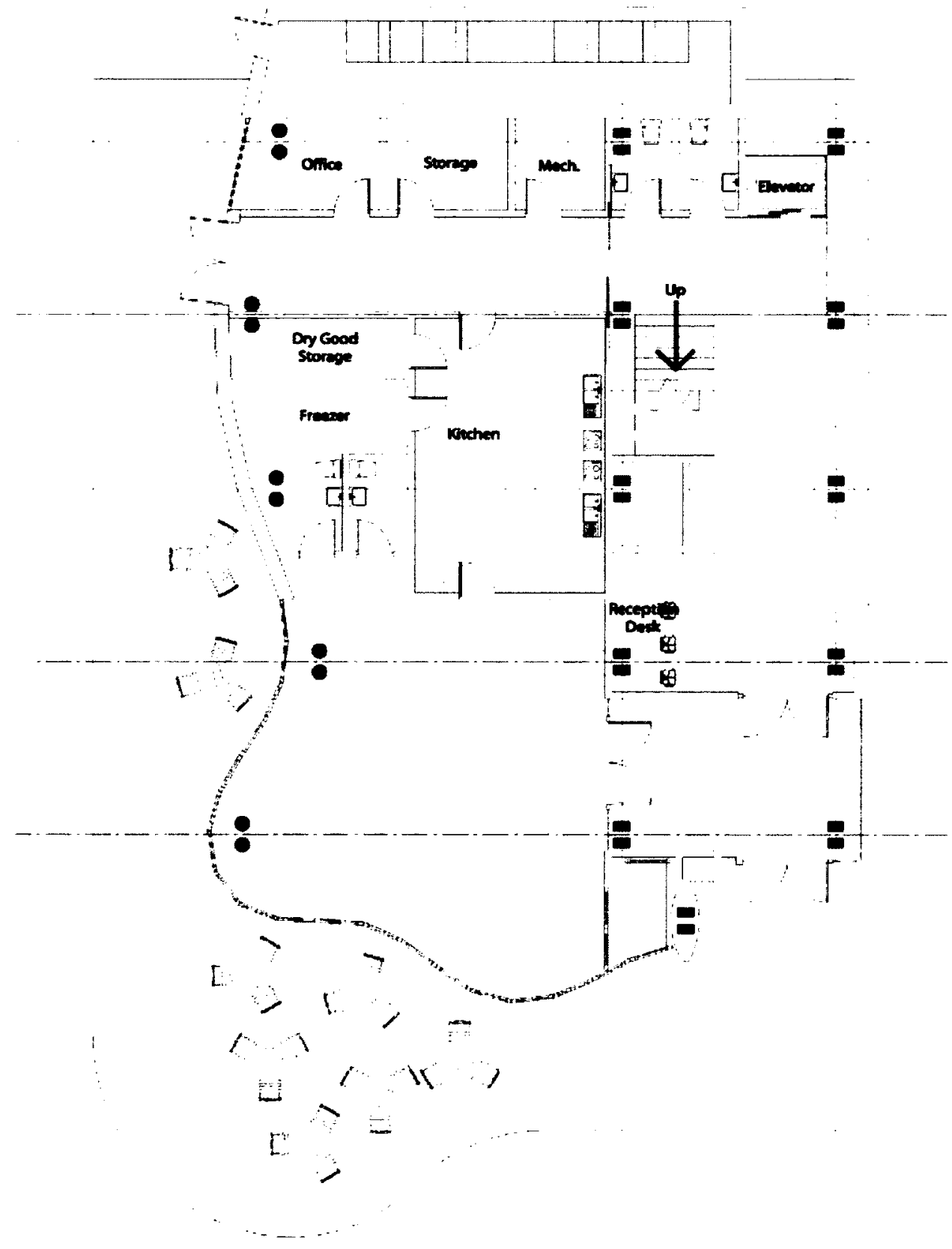

Figure 39 - Ground Floor Plan of Cafe \& Clinic (Design/Source: Greg Fung; Surrounding Buildings Massing Models Source: City of Ottawa retrieved from Carleton University Library; People, Trees, Automobiles and Cafe Table Source: Google) 


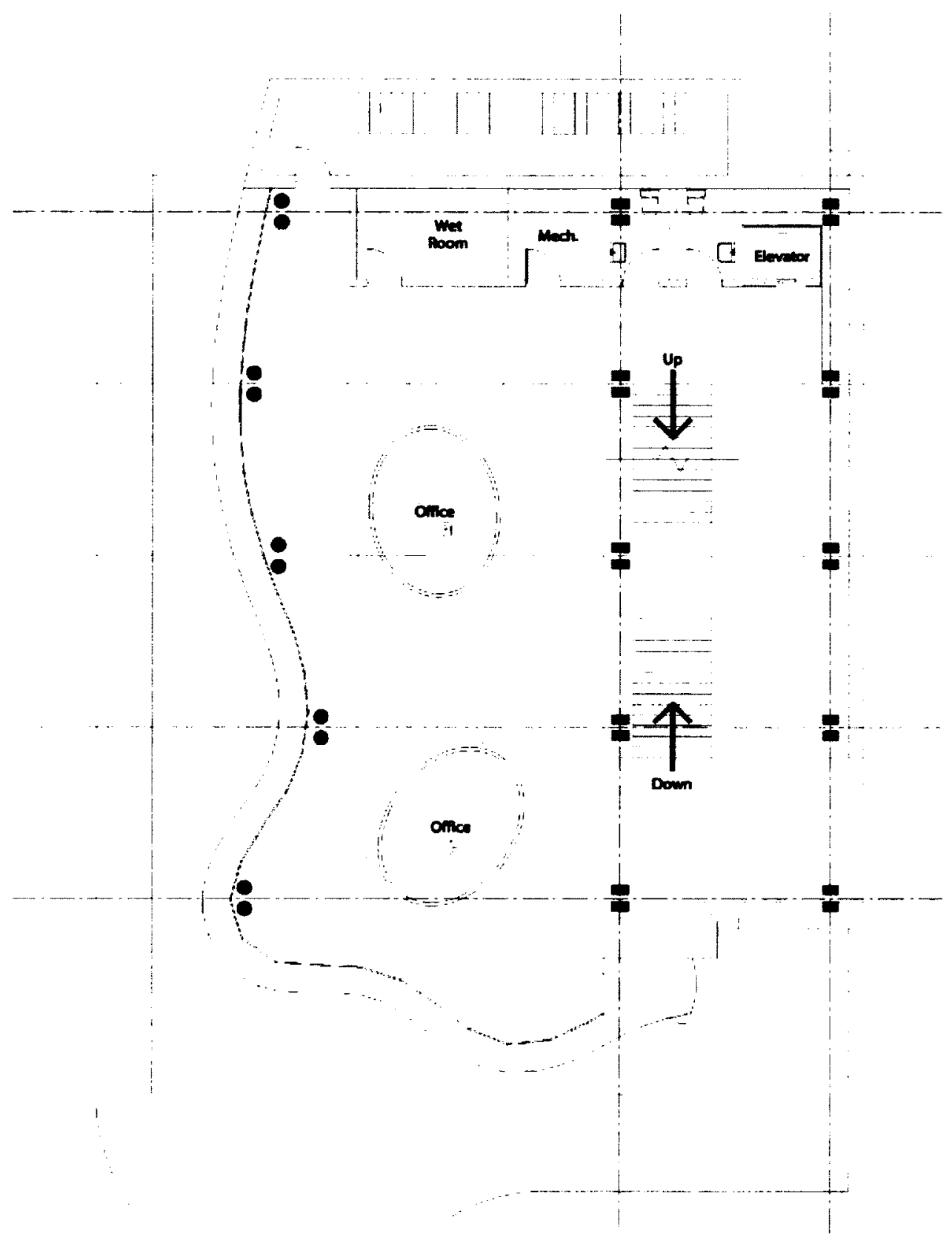

Figure 40 - Second Floor Plan of Cafe \& Clinic (Design/Source: Greg Fung; Surrounding Buildings Massing Models Source: City of Ottawa retrieved from Carleton University Library; People, Trees, Automobiles and Cafe Table Source: Google) 


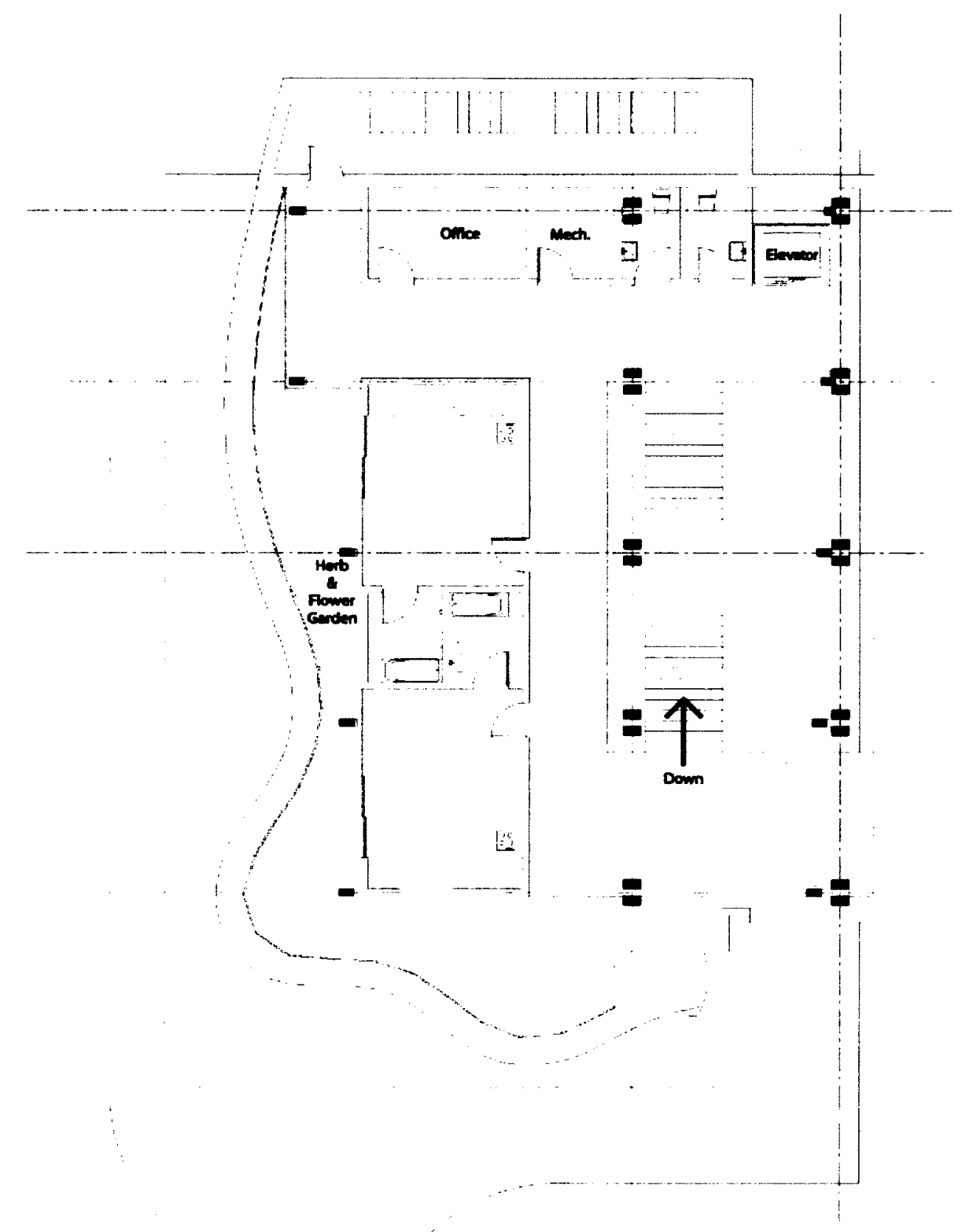

Figure 41 - Third Floor of Cafe \& Clinic (Design/Source: Greg Fung; Surrounding Buildings Massing Models Source: City of Ottawa retrieved from Carleton University Library; People, Trees, Automobiles and Cafe Table Source: Google) 


\section{Bibliography}

Books:

Aalto, Alvar. "The Humanizing of Architecture." Alvar Aalto in His Own Words. Eds. Göran Schildt. New York: Rizzoli, 1998. 102-107.

Ban, Shigeru. Alvar Aalto Through the Eyes of Shigeru Ban. Eds. Juhani Pallasmaa and Tomoko Sato. London: Black Dog Publishing, 2007.

Bloomer, Kent C. and Charles W. Moore. Body, Memory, and Architecture. New Haven and London: Yale University Press, 1977.

Calgary Heritage Authority. Historic Downtown Calgary: Including Calgary's National Historic District 'Stephen Avenue'. Calgary: Calgary Heritage Authority, 2005. Print. (Pamphlet)

Dorothy, Field. ed. Calgary: Stephen Avenue and Area Historical Walking Tour. Edmonton: Alberta Community Development, 1995. (Pamphlet)

Fainstein, Susan S. and Scott Campbell. eds. Readings in Urban Theory. Malden, MA: Wiley-Blackwell, 2011.

Fleig, Karl. ed. Alvar Aalto. Berlin: Birkhäuser, 1963. Fifth uncorrected reprint 1995. 30-43.

Filshie, Jacqueline and John W. Thompson. "8.2.9 Acupuncture." Oxford Textbook of Palliative Medicine. $3^{\text {rd }}$ Edition. Eds. Derek Doyle, Geoffrey Hanks, Nathan Cherny and Kenneth Calman. New York: Oxford University Press, 2005. 410-424.

Findley, Lisa. Building Change: Architecture, Politics and Cultural Agency. New York: Routledge, 2005.

Frampton, Kenneth. "Preface." A Matter of Things. Manuel de Solà-Morales, Kenneth Frampton and Hans Ibelings. Rotterdam: NAi Publishers, 2008. 7-9.

Gehl, Jan. Life Between Buildings: Using Public Space. $6^{\text {th }}$ Edition. Copenhagen: The Danish Architectural Press, 2006.

Goldsmith, Stephen A. and Lynne Elizabeth. eds. What We See: Advancing the Observation of Jane Jacobs. Oakland, CA: New Village Press, 2010. 
Heathcote, Edwin. "Architecture and Health". The Architecture of Hope: Maggie's Cancer Caring Centres. Charles Jencks and Edwin Heathcote. London: Frances Lincoln, 2010. 52-91.

Holl, Steven, Juhani Pallasmaa, Alberto Pérez-Gómez Question of Perception: Phenomenology of Architecture. San Francisco, CA: William Stout, 2006.

Ibelings, Hans. "The Architecture and Urban Design of Manuel de Solà-Morales." $A$ Matter of Things. Manuel de Solà-Morales, Kenneth Frampton and Hans Ibelings. Rotterdam: NAi Publishers, 2008. 10-14.

Kuriyama, Shigehisa. The Expressiveness of the Body and the Divergence of Greek and Chinese Medicine. New York: Zone Books, 1999.

Jencks, Charles and Edwin Heathcote. The Architecture of Hope: Maggie's Cancer Caring Centres. London: Frances Lincoln, 2010.

Lee, Laura. "Building a Life beyond Cancer: How Maggie's Centre Work". The Architecture of Hope: Maggie's Cancer Caring Centres. Charles Jencks and Edwin Heathcote. London: Frances Lincoln, 2010. 44-51.

Lerner, Jamie. "Reviving Cities." What We See: Advancing the Observation of Jane Jacobs. Eds. Stephen A. Goldsmith and Lynne Elizabeth. Oakland, CA: New Village Press, 2010. 184-191.

Pallasmaa, Juhani. The Eyes of the Skin: Architecture and the Senses. Hoboken, NJ: Jon Wiley \& Sons, 2005.

Pallasmaa, Juhani. "Space, Place, Memory, and Imagination: The Temporal Dimension of Existential Space." Spatial Recall: Memory in Architecture and Landscape. Ed. Marc Treib. New York: Routledge, 2009. 16-41.

Schildt, Göran. "Paimio Tuberculosis Sanatorium 1929." Alvar Aalto: Master Works. New York: Universe Publications, 1998. 19-27.

Schwartzeberg, Susan. "Re-creating the Past: notes on the Neurology of Memory." Spatial Recall: Memory in Architecture and Landscape. Ed. Marc Treib. New York: Routledge, 2009. 42-61.

Solà-Morales, Manuel de, Kenneth Frampton and Hans Ibelings. A Matter of Things. Rotterdam: NAi Publishers, 2008.

Sternberg, Esther M. Healing Spaces: The Science of Place and Well-Being. Cambridge, Massachusetts: Belknap Press of Harvard University Press, 2009. 
St. John Wilson, Colin. The Other Tradition of Modern Architecture: The Uncompleted Project. London : Academy Editions, 1995.

Treib, Marc. ed. Spatial Recall: Memory in Architecture and Landscape. New York: Routledge, 2009.

Zardini, Mirko. ed. Sense of the City: An Alternative Approach to Urbanism. Montreal, QC: Canadian Centre for Architecture, 2005.

\section{Journals:}

Anderson, Diana. Humanizing the hospital: Design Lessons from a Finnish sanatorium. CMAJ (Canadian Medical Association), 2010. 10 August 2009. Web. 8 March 2012. < http://www.cmaj.ca/content/182/11/E535.full.pdf>

Allchin, Douglas. "Points East and West: Acupuncture and Comparative Philosophy of Science". Philosophy of Science, Vol. 63, Supplement. Proceedings of the 1996 Biennial Meetings of the Philosophy of Science Association. Part I: Contributed Papers (Sep., 1996): S107-S115. The University of Chicago Press (on behalf of the Philosophy of Science Association). Web. 27 March 2012. <http://www.jstor.org/stable/188517>

Bowers, John Z. "Acupuncture." Proceedings of the American Philosophical Society, Vol. 117, No. 3 (Jun. 15, 1973): 143-151. American Philosophical Society. Web. 15 May 2012. <http://www.jstor.org/stable/986539>

Campbell, Margaret. "What Tuberculosis did for Modernism: The Influence of a Curative Envirønment on Modernist Design and Architecture." Medical History (1 October 2005), 49(4): 463-448. Web. 8 April 2012.

$<$ http://www.ncbi.nlm.nih.gov/pmc/articles/PMC1251640/>

Francis, Susan. "The architecture of health buildings: Providing care - can architects help?" The British Journal of General Practice March 2002: 254-255. PubMed Central. US National Library of Medicine, National Institutes of Health. . Web. 3 April 2012. $<$ http://www.ncbi.nlm.nih.gov/pmc/articles/PMC1314261/pdf/12030685.pdfs

Heathcote, Edwin. "Maggie's Centres". BMJ: British Medical Journal, Vol. 333, No. 7582 (23-30 December 2006), pp. 1304-1305. BMJ Publishing Group. Web. 3 April 2012. <http://www.jstor.org/stable/40700587>

Marmot, Alexi. "Architectural Determinism: Does Design Change Behaviour?" The British Journal of General Practice March 2002: 252-253. PubMed Central . US National Library of Medicine, National Institutes of Health. Web. 3 April 2012. $<$ http://www.ncbi.nlm.nih.gov/pmc/articles/PMC1314261/pdf/12030685.pdf $>$ 
Mayor, Susan. "Cancer Centre Provides Spaces for Patients to Think". BMJ: British Medical Journal, Vol. 336, No. 7651 (May 3, 2008), p. 978. BMJ Publishing Group. Web. 3 April 2012. <http://www.jstor.org/stable/20509633>

Pagel, Walter. "Prognosis and Diagnosis: A Comparison of Ancient and Modern Medicine." Journal of the Warburg Institute, Vol. 2, No. 4 (Apr. 1939): 382-398. Web. < http://www.jstor.org/stable/750046>

Ulrich, R. S. "View through a window may influence recovery from surgery". Science, 224 (4647), 1984: 420-421. Web. 29 March 2012.

<http://www.jstor.org/stable/1692984?origin=JSTOR-pdf>

\section{Digital Articles and Books:}

Blakenham, Marcia. Maggie's Centres: Marching On. No Publisher, London: 2007. Web. $<$ http://www.maggiescentres.org/maggies/dms/maggiescentres/publications/general/VFT FL>

British Medical Association. The Psychological and Social Needs of Patients. BMA Science \& Education. British Medical Association. London, 2011. Web. 2012 May 26. $<\mathrm{http}: / /$ www.bma.org.uk/images/psychologicalsocialneedsofpatients_tcm41-202964.pdf>

Calgary Downtown Association. Stephen Avenue Walk Directory. Calgary Downtown Association, Calgary: May 2010. Web. 06 June 2012.

$<$ http://www.downtowncalgary.com/imagedir/Stephen Avenue Directory final(2).pdf $>$

Jencks, Maggie Keswick. A View From the Front Line. No Publisher, London: 1995. (Reprinted 2003 and 2007) Web.

$<$ http://www.maggiescentres.org/maggies/dms/maggiescentres/publications/general/VFT FL>

Neill, David Leigh. "Historic Districts and Their Role as Sustainable Regenerators of Downtown City Life". Thesis. University of Calgary, 2011. Web. 31 May 2012. $<$ http://dspace.ucalgary.ca/bitstream/1880/48432/1/2011_Neill_PhD.pdf>

Roecker, Inge and Kelty Miyoshi Mckinnon. Urban Acupuncture: A Methodology for the Sustainable Rehabilitation of 'Society Buildings' in Vancouver's Chinatown into Contemporary Housing. Canada Mortgage and Housing Corporation, External Research Program, 2006. Web. 11 March 2012. $<$ <ttp://books.scholarsportal.info/viewdoc.html?id=32786> 
Stevenson, Fionn \& Mike kHumphris. A Post Occupancy Evaluation of the Dundee Maggie Centre. Ecological Design Group, School of Architecture, University of Dundee: March 2007.

Ulrich, Roger S. Health Benefits of Garden in Hospitals. Plants for People, International Exhibition Floriade, 2002. Web. 31 March 2012.

$<$ http:/greenplantsforgreenbuildings.org/attachments/contentmanagers/25/HealthSettings Ulrich.pdf $>$

Yee, Paul. Chinatown: an illustrated history of the Chinese communities of Victoria, Vancouver, Calgary, Winnipeg, Toronto, Ottawa, Montreal and Halifax. Toronto: J. Lorimer, 2005. 2005. Web. 14 January 2012.

<http://site.ebrary.com.proxy.library.carleton.ca/lib/oculcarleton/docDetail.action?docID $=10210337>$

Web:

A.D.A.M. Medical Encyclopedia. Seasonal affective disorder. A.D.A.M. Medical Encyclopedia. U.S. National Library of Medicine. A.D.A.M., Inc. 2012. Web. 31 March 2012. <http://www.ncbi.nlm.nih.gov/pubmedhealth/PMH0002499/>

Canada's Role in Fighting Tuberculosis, Yesterday, Today and Tomorrow. Canada's Digital Collections program, Industry Canada. Canada Lung Association. Web. 13 April 2012. < http://www.lung.ca/tb/>

City of Ottawa. Ottawa Through Time From the Andrews-Newton Photographs: Green Belt. City of Ottawa. 2001-2012. Web. 26 March 2012.

$<$ http://ottawa.ca/en/rec_culture/museum_heritage/archives/history/construction/greenbel t/index.html; Permalink: http://ottawa.ca/e/CON060265>

City of Ottawa. Official Plan Consolidation for the City of Ottawa-October 2011 Section 1: Introduction. City of Ottawa. October 2011. Web. 26 March 2012. <http://www.ottawa.ca/cs/groups/content/@webottawa/documents/pdf/mdaw/mdqy/_edis p/con015300.pdf $>$

City of Ottawa. Ottawa 20/20 Official Plan: 3.5 Greenbelt. City of Ottawa. 2001-2012. Web. 26 March 2012.

<http://www.ottawa.ca/city_hall/ottawa2020/official_plan/vol_1/03_design_land_use/ind ex_en-05.html>

City of Ottawa. Ottawa 20/20 Official Plan: Preston-Champagne 6.1 Vision. City of Ottawa. Web. 26 March 2012. <

http://www.ottawa.ca/city_hall/ottawa2020/official_plan/vol_2a/former_ottawa/preston/i ndex_en-02.html> 
City of Ottawa. Ottawa 20/20 Official Plan: Preston-Champagne 6.4 Policies. City of Ottawa. Web. 26 March 2012.

$<$ http://www.ottawa.ca/city_hall/ottawa2020/official_plan/vol_2a/former_ottawa/preston/ index_en-04.html>

City of Ottawa. Official Plan Consolidation for the City of Ottawa - January 2007 Prologue. City of Ottawa. January 2007. Web. 26 March 2012.< http://www.ottawa.ca/cs/groups/content/@webottawa/documents/pdf/mdaw/mdy3/-edisp /con015296.pdfs

City of Ottawa. Ottawa 20/20 Official Plan: 3.5 Greenbelt. City of Ottawa. 2001-2012. Web. 26 March 2012.

$<$ http://www.ottawa.ca/city_hall/ottawa2020/official_plan/vol_1/03_design_land_use/ind ex_en-05.html>

City of Ottawa. Profiling Progress - An Introduction to Ottawa. City of Ottawa. Web. 26 March 2012.

$<$ http://ottawa.ca/en/city_hall/planningprojectsreports/annual_report/2004/profiling_prog ress/, http://ottawa.ca/e/W $3002885>$

City of Ottawa. Somerset West Reconstruction. City of Ottawa. Web. 26 March 2012. $<$ http://ottawa.ca/en/city_hall/planningprojectsreports/construction/projects/somerset_we st/; Permalink: http://ottawa.ca/e/CON051296 >

Darwin, Eric. Ottawa Chinatown Royal Arch. 08 October 2010. Web. 26 March 2012. <http://ottawachinatownroyalarch.blogspot.ca/>

Jaime Lerner Profile on TED. TED Conferences, LLC. Web. 25 March 2012.

$<$ http://www.ted.com/speakers/jaime_lerner.html >

Kreitzer, Mary Jo. What Impact Does the Environment Have on Us? Taking Charge of Your Health. University of Minnesota. February 2009. Web. 29 March 2012.

$<$ http://takingcharge.csh.umn.edu/explore-healing-practices/healing-environment/whatimpact-does-environment-have-us>

Lerner, Jaime. Jamie Lerner Sings of the City. TED Conferences, LLC. March 2007. Video, Web. 25 March 2012.

<http://www.ted.com/talks/jaime_lerner_sings_of_the_city.html $>$

National Capital Commission. Fact Sheet: Overview of the new Greenbelt Master Plan Recommended Land Use Concept. . 25 January 2012. Web. 26 March 2012.

$<$ http://www.canadascapital.gc.ca/places-to-visit/greenbelt/news/2012-01-25/fact-sheetoverview-of-new-greenbelt-master-plan>

Statistics Canada Population of census metropolitan areas. Statistics Canada, 07 March 2012. Web. 26 March 2012. <http://www40.statcan.gc.ca/101/cst01/demo05a-eng.htm> 
The Maggie Keswick Jencks Cancer Caring Centres Trust. Maggie 's Cancer Caring Centres. Web. December 27, 2011. <http://www.maggiescentres.org >

What is Tuberculosis? How is Tuberculosis Treated? Canada's Digital Collections program, Industry Canada. Canada Lung Association. Web. 8 April 2012.

<http://www.lung.ca/tb/abouttb/what/treated_tb.html>

Video:

Chinese Medicine. Films Media Group, 2007. Films On Demand. 2007. Web. 17 January 2012.

<http://digital.films.com.proxy.library.carleton.ca/PortalPlaylists.aspx aid=15652\&xtid= $40021>$. 